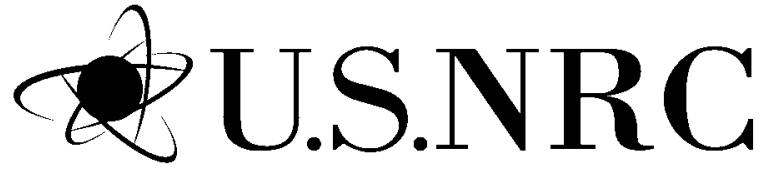

United States Nuclear Regulatory Commission

$\overline{\text { Protecting People and the Environment }}$

\title{
Transfer Factors for Contaminant Uptake by Fruit and Nut Trees
}




\section{AVAILABILITY OF REFERENCE MATERIALS IN NRC PUBLICATIONS}

\section{NRC Reference Material}

As of November 1999, you may electronically access NUREG-series publications and other NRC records at NRC's Public Electronic Reading Room at http://www.nrc.gov/reading-rm.html. Publicly released records include, to name a few, NUREG-series publications; Federal Register notices; applicant, licensee, and vendor documents and correspondence; NRC correspondence and internal memoranda; bulletins and information notices; inspection and investigative reports; licensee event reports; and Commission papers and their attachments.

NRC publications in the NUREG series, NRC regulations, and Title 10, "Energy," in the Code of Federal Regulations may also be purchased from one of these two sources.

1. The Superintendent of Documents

U.S. Government Printing Office

Mail Stop SSOP

Washington, DC 20402-0001

Internet: bookstore.gpo.gov

Telephone: 202-512-1800

Fax: 202-512-2250

2. The National Technical Information Service Springfield, VA 22161-0002

www.ntis.gov

1-800-553-6847 or, locally, 703-605-6000

A single copy of each NRC draft report for comment is available free, to the extent of supply, upon written request as follows:

Address: U.S. Nuclear Regulatory Commission

Office of Administration

Publications Branch

Washington, DC 20555-0001

E-mail: DISTRIBUTION.RESOURCE@NRC.GOV

Facsimile: 301-415-2289

Some publications in the NUREG series that are posted at NRC's Web site address http://www.nrc.gov/reading-rm/doc-collections/nuregs are updated periodically and may differ from the last printed version. Although references to material found on a Web site bear the date the material was accessed, the material available on the date cited may subsequently be removed from the site.

\section{Non-NRC Reference Material}

Documents available from public and special technical libraries include all open literature items, such as books, journal articles, transactions, Federal Register notices, Federal and State legislation, and congressional reports. Such documents as theses, dissertations, foreign reports and translations, and non-NRC conference proceedings may be purchased from their sponsoring organization.

Copies of industry codes and standards used in a substantive manner in the NRC regulatory process are maintained at-

The NRC Technical Library

Two White Flint North

11545 Rockville Pike

Rockville, MD 20852-2738

These standards are available in the library for reference use by the public. Codes and standards are usually copyrighted and may be purchased from the originating organization or, if they are American National Standards, from-

American National Standards Institute

11 West $42^{\text {nd }}$ Street

New York, NY 10036-8002

www.ansi.org

212-642-4900

Legally binding regulatory requirements are stated only in laws; NRC regulations; licenses, including technical specifications; or orders, not in NUREG-series publications. The views expressed in contractorprepared publications in this series are not necessarily those of the NRC.

The NUREG series comprises (1) technical and administrative reports and books prepared by the staff (NUREG-XXXX) or agency contractors (NUREG/CR$X X X X),(2)$ proceedings of conferences (NUREG/CP$X X X X)$, (3) reports resulting from international agreements (NUREG/IA-XXXX), (4) brochures (NUREG/BR-XXXX), and (5) compilations of legal decisions and orders of the Commission and Atomic and Safety Licensing Boards and of Directors' decisions under Section 2.206 of NRC's regulations (NUREG0750).

DISCLAIMER: This report was prepared as an account of work sponsored by an agency of the U.S. Government. Neither the U.S. Government nor any agency thereof, nor any employee, makes any warranty, expressed or implied, or assumes any legal liability or responsibility for any third party's use, or the results of such use, of any information, apparatus, product, or process disclosed in this publication, or represents that its use by such third party would not infringe privately owned rights. 
United States Nuclear Regulatory Commission

Protecting People and the Environment

\section{Transfer Factors for Contaminant Uptake by Fruit and Nut Trees}

Manuscript Completed: November 2013

Date Published: July 2014

Prepared by:

B. A. Napier

R. J. Fellows

L. D. Minc

Pacific Northwest National Laboratory

P. O. Box 999

Richland, WA 99352

P. R. Reed, NRC Project Manager

NRC Job Codes N6455 and V6237

Office of Nuclear Regulatory Research 



\begin{abstract}
Transfer of radionuclides from soils into plants is one of the key mechanisms for longterm contamination of the human food chain. Plants absorb nutrients through their roots and transport them via the phloem to active portions of the plant. Nearly all computer models that address soil-to-plant uptake of radionuclides use empirically-derived transfer factors to address this process. Essentially all available soil-to-plant transfer factors are based on measurements in annual crops. Very few measurements are available for tree fruits.

In order to address this limitation, a sampling of various "standard" crops and fruit and nut trees from a single farm was made. This particular farm uses irrigation water from the local aquifer using surface irrigation (not overhead sprinklers) and is registered as an organic farm (no pesticides or refined fertilizers are used). Samples of alfalfa and oats (to compare with available transfer factors) and stems, leaves, and fruits and nuts of almond, apple, apricot, carob, fig, grape, nectarine, pecan, pistachio (natural and grafted), and pomegranate were collected, along with local surface soil. The samples were dried, ground, weighed, and analyzed for trace constituents through a combination of induction-coupled plasma mass spectrometry and instrumental neutron activation analysis for a wide range of naturally-occurring elements.

Analysis results are presented and converted to soil-to-plant transfer factors. These are compared to commonly used and internationally recommended values. Those determined for annual crops (e.g., alfalfa, grain (oats)) are very similar to commonlyused values; those determined for fruits and nuts differ from the generic recommendations in the literature. In most cases, the results of the transfer factors in fruits and nuts from this study are the only data available. Transfer factors for most macro- and micronutrients are slightly reduced in fruits from the generic recommendations; transfer factors for non-essential elements are reduced further. The results tend to support the use of chemical analogues for elements that are not homeostatically regulated (i.e., those for which internal levels are not regulated by the plant at optimal concentrations). These different findings may allow development of tree-fruit-specific transfer models.
\end{abstract}





\section{CONTENTS}

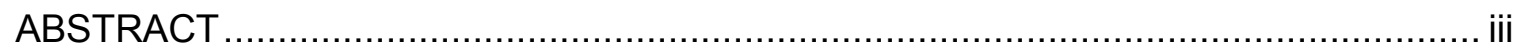

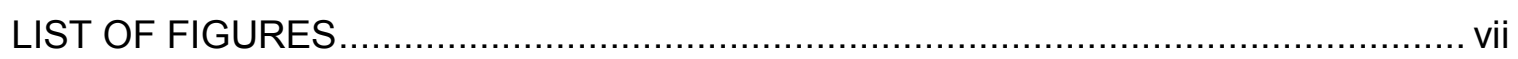

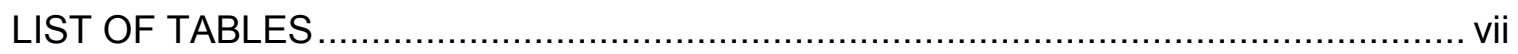

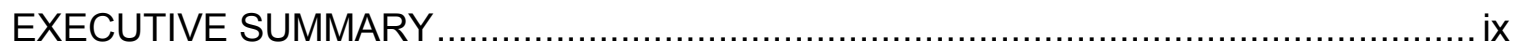

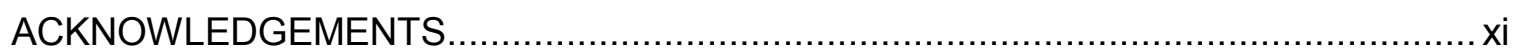

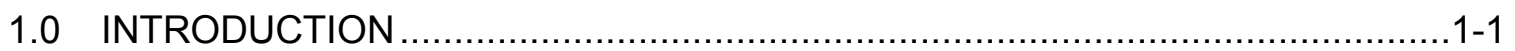

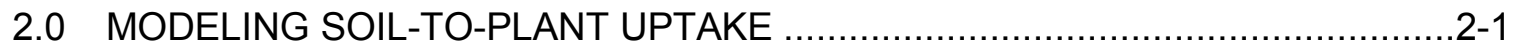

2.1 Radionuclide Behavior in Soils and Plant Uptake...................................2-1

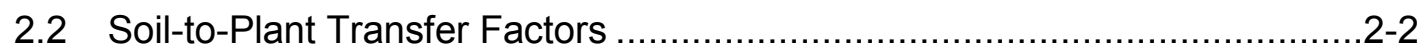

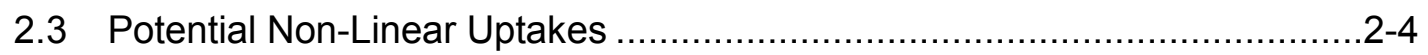

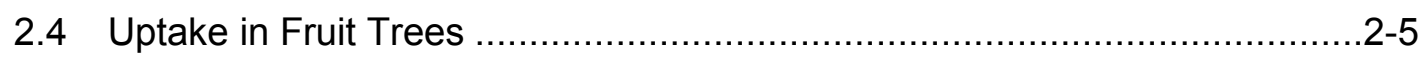

3.0 SAMPLING AND ANALYSIS OF SOIL AND FRUIT SAMPLES …....................

3.1 Sampling and Analysis of Soil Samples ....................................................

3.1.1 Characterization and Analysis of Bulk Soil Samples ........................ $3-1$

3.1.1.1 X-ray Diffraction .......................................................... $3-2$

3.1.1.2 Elemental Analysis by X-ray Fluorescence .......................3-2

3.1.1.3 Particle Size Distribution ............................................... $3-3$

3.1.1.4 Moisture Content.....................................................

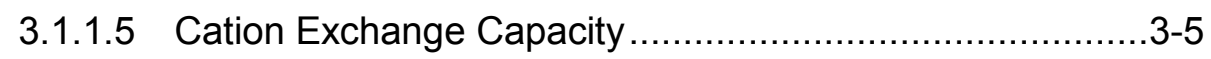

3.1.1.6 Carbon Content.............................................................

3.2 Sampling and Analysis of Crop and Fruit Samples.....................................

3.2.1 Methods for Analysis of Vegetation Samples..................................

3.2.1.1 Mass Spectrometry ......................................................

3.2.1.2 Instrumental Neutron Activation Analysis .......................3-10

4.0 SOIL-TO-PLANT TRANSFER FACTORS ............................................... 4 -1

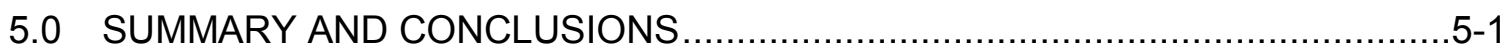

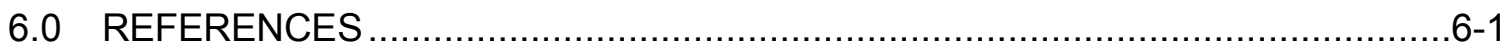

APPENDIX A. RESULTS OF ANALYSES AND CHARACTERIZATION OF SOIL, CROP, AND FRUIT SAMPLES ....................................................... 



\section{LIST OF FIGURES}

Figure 2.1 Relationships between Tissue Concentrations and Environmental Concentrations for Non-nutrient and Nutrient Compounds. ..................2-4

Figure 3.1 Background-Subtracted XRD Pattern for Nye County Soil Sample .......3-3

Figure 3.2 Plants Sampled - Grafted and Natural Pistachio, Fig ......................... 3-8

Figure 3.3 Plants Sampled - Field Crops Alfalfa and Oats, Fruits and Nuts Almond, Apricot, Carob, and Nectarine

\section{LIST OF TABLES}

Table 2.1 A Biological Classification of Metals: Shaded Cells are Non-nutrient Analogs; Bold Cells are Nonessential Metals. ................................. 2-5

Table 3.1 Concentrations of Major Elements in Bulk Soil Samples as Determined by XRF

Table 3.2 Concentrations of Trace Elements in Bulk Soil Samples as Determined by XRF.

Table 3.3 Particle Size Analysis of the Bulk Soil Samples..................................

Table 3.4 Moisture Contents of the Bulk Soil Samples....................................... $3-5$

Table 3.5 Cation Exchange Capacity (CEC) Values for the Soil Samples ............. 3-5

Table 3.6 Carbon Contents of the Soil Samples.............................................

Table $3.7 \quad$ Elemental Results from ICAP-MS analysis.................................. $3-7$

Table 4.1 Soil-to-Plant Transfer Values for Forage and Grain from this Study, Compared to Those in Current Use (unitless) ....................................4-3

Table 4.2 Transfer Factors for Almonds (unitless) ...................................... $4-4$

Table $4.3 \quad$ Transfer Factors for Apples (unitless) ........................................ $4-5$

Table $4.4 \quad$ Transfer Factors for Apricots (unitless) ......................................... $4-6$

Table $4.5 \quad$ Transfer Factors for Carob (unitless) ........................................... 4-7

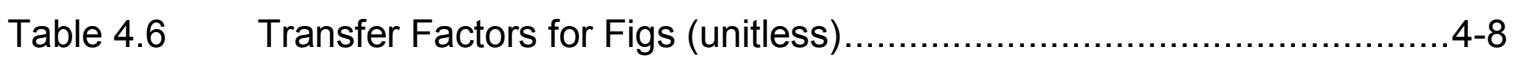

Table $4.7 \quad$ Transfer Factors for Grapes (unitless) ...................................... $4-9$

Table 4.8 Transfer Factors for Nectarines (unitless)................................... 4-10

Table 4.9 Transfer Factors for Pecans (unitless).........................................4-11

Table 4.10 Transfer Factors for Grafted Pistachios (unitless).............................4-12

Table 4.11 Transfer Factors for Natural Pistachios (unitless) ........................... 4-13

Table 4.12 Transfer Factors for Pistachios (Natural + Grafted) (unitless) ..............4-14

Table 4.13 Transfer Factors for Pomegranates (unitless) ...................................4-15

Table 4.14 Transfer Factors for Generic Fruit and Nut Trees (unitless)................4-16 



\section{EXECUTIVE SUMMARY}

Transfer of radionuclides from soils into plants is one of the key mechanisms for longterm contamination of the human food chain. Plants absorb nutrients through their roots and transport them via the phloem to active portions of the plant. Nearly all computer models that address soil-to-plant uptake of radionuclides use empirically-derived transfer factors to address this process. Essentially all available soil-to-plant transfer factors are based on measurements in annual crops. Very few measurements are available for tree fruits.

In order to address this limitation, a sampling of various "standard" crops and fruit and nut trees was made. Samples of alfalfa and oats (to compare with available transfer factors) and stems, leaves, and fruits and nuts of almond, apple, apricot, carob, fig, grape, nectarine, pecan, pistachio (natural and grafted), and pomegranate were collected, along with local surface soil. The samples were dried, ground, weighed, and analyzed for trace constituents through a combination of induction-coupled plasma mass spectrometry and instrumental neutron activation analysis for a wide range of naturallyoccurring elements.

Analysis results are presented and converted to soil-to-plant transfer factors. These are compared to commonly used and internationally recommended values. Those determined for annual crops (e.g., alfalfa, grain (oats)) are very similar to commonlyused values; those determined for fruits and nuts differ from the generic recommendations in the literature. In most cases, the results of the transfer factors in fruits and nuts from this study are the only data available. 



\section{ACKNOWLEDGEMENTS}

The authors are particularly grateful for the technical guidance, review, and encouragement provided by P. R. Reed of the U.S. Nuclear Regulatory Commission. The authors thank NRC staff for detailed review comments on the draft of this report. 



\subsection{INTRODUCTION}

Transfer of radionuclides from soils into plants is one of the key mechanisms for longterm contamination of the human food chain. Plants absorb nutrients through their roots and transport them via the phloem to active portions of the plant. Nearly all computer models that address soil-to-plant uptake of radionuclides use empirically-derived transfer factors to address this process. Essentially all available soil-to-plant transfer factors are based on measurements in annual crops. Very few measurements are available for tree fruits. In order to address this limitation, a sampling of various "standard" crops and tree fruits, and the soils that they were growing in, were made from a single farm. Analyses of stable element concentrations were performed for the soils and the crops and various parts of the trees and fruits. The concentrations of numerous elements have been compared to provide soil-to-plant transfer factors for a range of fruits under-represented in the radioecological literature.

Section 2 of this report describes some key concepts in biosphere modeling including radionuclide behavior in soils and uptake from soil by plant roots. Each of these is an area addressed by research detailed in this report.

Section 3 of this report provides descriptions of the sampling location, sample collection and preparation, and sample analysis. Samples of several types of fruit trees, including branches, leaves, and fruits were collected and analyzed for stable element concentrations. The resulting concentration data are provided in Appendix A of this report.

Section 4 presents the results as soil-to-plant transfer factors for future use in radiological analyses. The results are compared to transfer factor values routinely used in radiological analyses, and observations are made related to uptakes of elements that are either nutrients or non-essential elements, as well as to the reliability of use of surrogate measures such as chemical similarity for chemically-similar but unmeasured materials.

The results are expected to be useful in:

- Supporting the development of regulatory criteria (e.g., guidance, technical positions) for food-chain pathway issues involving biosphere models

- Providing a basis for developing and evaluating biosphere and food-chain pathway data, information, analyses, conceptual models, and computer codes

- Providing data and information for resolving biosphere issues involving possible future development of predictive models for radionuclide uptake in fruits.

The results of the research program improve the understanding of the features and processes for some important long-lived radionuclides in biosphere modeling. 



\subsection{MODELING SOIL-TO-PLANT UPTAKE}

The following discussion is adapted from a longer presentation in Napier (2006). There are a number of important features and processes that all biosphere models must address in some manner (UNSCEAR 2000). The primary inputs to estimating radiation doses to individuals and populations are the concentrations and availabilities of radionuclides in air, water, soil, and foods, and the level of exposure of the individuals or groups to each radionuclide in each medium. Because it is not possible to completely characterize the radiological environment, and because in many practical cases the concentration of radionuclides in the environment resulting from reactor operations is too low to measure, mathematical models are employed to go from what is known to what needs to be known. For terrestrial models, these include radionuclide behavior in soil and uptake from soil by plant roots.

\subsection{Radionuclide Behavior in Soils and Plant Uptake}

Terrestrial plants, as immobile organisms, have adapted to derive essential nutrients from their environments. Plants absorb nutrients through their roots and transport them via the phloem to active portions of the plant. Biotic factors are likely the source of much of the variability seen in concentrations of contaminants in plants. This variability results from the nature of the sessile terrestrial plant and its relationship with its environment: the need to compete and acquire specific nutrient species from soils (or to avoid uptake of excesses of potentially toxic materials), the need of individual plant types for specific levels of individual nutrients, and the use of certain metals in tissues as agents to discourage herbivory. Thus, the uptake is affected by the following biotic factors:

1. The plant-available concentration in soils within the rhizosphere (the soil zone that surrounds and is influenced by the roots of plants), which is governed by soil adsorption processes, chemical solubility, microbial/fungal activity, and stability of the chemical complexes;

2. The chemical nature and stability of the cation-anion/complex with respect to the plant's capability to metabolically alter and/or absorb the elemental form into the plant

3. A series of plant adaptive/evolutionary processes for survival; this can include, but not be limited to, protective root processes (exclusion or complexation of an ion for detoxification, sequestration within the plant to regulate both ion levels and for detoxification, redox to alter solubility and transport when necessary, organic complexation in the case of all but mono-cationic elements, and uptake capacity being dependent on metabolic needs).

Under these chemical and biotic constraints, uptake can be expected to vary based on source term, kinetics of solubilization/speciation, the relative ability of a plant to view a non-nutrient ion as an analogue to a nutrient species, and the relative need by the individual plant genus/species for specific levels of a particular ion. 
Transfer of radionuclides from soils into plants is one of the key mechanisms for longterm contamination of the human food chain. There are several methods that may potentially be used to simulate this process in radioecological models; the most common is through the use of soil-to-plant transfer factors (or concentration ratios), but others may also be used.

\subsection{Soil-to-Plant Transfer Factors}

The concept of soil-to-plant transfer factors has a long history. The document series Prediction of the Maximum Dosage to Man from the Fallout of Nuclear Devices (Tamplin 1967; Ng and Thompson 1966; Burton and Pratt 1968; Ng et al. 1968) was intended to provide input in the design of nuclear explosives to minimize the impacts of fallout; a series of appendices to $\mathrm{Ng}$ et al. (1968) described how global average concentrations of stable elements in soils and plants could be ratioed to give an estimate of uptake of radionuclides in plants from contaminated soils. In this description, $\mathrm{Ng}$ used the symbol $\left(\mathrm{C}_{\mathrm{P}} / \mathrm{C}_{\mathrm{S}}\right)$ for what he called the plant-to-soil concentration ratio. The data in this report became the basis for many later models and calculations, such as NRC Regulatory Guide 1.109 (NRC 1977).

The concept pioneered by $\mathrm{Ng}$ has been given many names over the years.

- Plant-to-soil concentration ratio - a generic term in ecology, used by Whicker and Schultz (1982), Peterson (1983), Faw and Shultis (1999), and others;

- Soil-to-plant transfer factor - used to describe the direction of radionuclide migration "from soil into plants", adopted by Martin Frissell and the International Union of Radioecologists (1989), IAEA (1994), and others;

- Vegetable/soil transfer factor - used in documents related to the RESRAD family of computer codes (e.g., Yang, Biwer, and Yu 1993; Yu et al. 2001);

- Soil-to-plant concentration ratio - a variant used by NCRP (1984);

- Soil-to-plant concentration factor - a variant used by IAEA (1982), Ng, Colsher, and Thompson (1982);

- Concentration factor - a variant used by Soldat in Fletcher and Dotson (1971); Miller et al. (1980);

- Transfer ratio - Stannard (1988);

- Concentration ratio - a commonly-used variant (e.g., Cataldo, Wildung, and Garland 1983; Napier et al. 2012; numerous others);

- Plant uptake factor - Eisenbud (1987);

- Relative ratio - Dahlman and Van Voris (1976);

- Uptake ratio - Grummitt (1976);

- Plant bioconcentration factor - a definition more usually used for aquatic uptake processes, sometimes used with terrestrial vegetation (e.g., Wolterbeek, van der Meer, and Dielemans 2000);

- Plant bioaccumulation factor - a definition more usually used for aquatic uptake processes, sometimes used with terrestrial vegetation (e.g., Wolterbeek, van der Meer, and Dielemans 2000)

- Discrimination factor - the name sometimes given to the ratio of the steady state output to input of a compartment model, when applied to the ratio of concentration in soil to concentration in plant, also accumulation factor (Peterson 1983; Faw and Shultis 1999). 
All of these concepts are the same; the notation generally used for the transfer factor is $B_{v}$ and is the unitless ratio of the concentration of an element in a plant of interest to the concentration in the source soil. The transfer factor applies to long-term, chronic exposures and is ideally measured at equilibrium. Transfer factors are used in risk assessments to estimate the amount of radioactivity that could be present in a food crop based on the calculated concentration in the source soil. By calculating the concentration in the food, the total intake can be estimated and a dose calculated as a result of the annual intake. In terms of radionuclides, the transfer factor is used to calculate how many becquerels per kilogram of soil are transferred to the edible dry plant product (Bq per $\mathrm{kg}$ ). Although the concept is occasionally questioned for some of its underlying assumptions (e.g., Centofani et al. 2005), it is the most commonly used approach in radiological environmental assessments.

The transfer factor depends on the radionuclide, the soil type (which may include soil chemistry and concentrations of nutrients and analogues), and the plant type. The transfer factors are empirically derived; they are based on measurements made for various chemical forms of the radionuclide on selected types of plant in selected soil types. Experimental data are not available for all elements for all food types.

Frequently, a few measurements on a very limited number of plant types are used to infer a transfer factor for all crops. Often, when no referenceable documents are available, data are derived based on chemical groupings in the periodic table of the elements, such that chemically similar elements are assigned similar values.

Since the handbook prepared by Ng et al. (1968), numerous studies have been undertaken to quantify transfer factors (or concentration ratios) for specific chemical elements as a function of food type. These studies have been compiled in several publications. Most computer codes reference one or more of these compilations as the source of their transfer factors. Several frequently referenced compilations include the International Atomic Energy Agency's Technical Report Series \#364, Handbook of Parameter Values for the Prediction of Radionuclide Transfer in Temperate Environments (IAEA 1994). This document encompasses a wide variety of plant types and is the result of extensive background investigations. It is based on data compiled by the International Union of Radioecologists. This document has recently been updated (IAEA 2009; IAEA 2010). A second frequently cited reference is the NUREG/CR-5512, Residual Radioactive Contamination From Decommissioning: Technical Basis for Translating Contamination Levels to Annual Total Effective Dose Equivalent (Kennedy and Strenge 1992) because of its large set of data and traceable references. Other references include the National Council on lonizing Radiation and Protection (NCRP) Report \#123 (1996), Screening Models for Releases of Radionuclides to Atmosphere, Surface Water, and Ground, and the series of documents by Coughtrey and Thorne (1983), Radionuclide Distribution and Transport in Terrestrial and Aquatic Ecosystems, Vols. 1-6.

Root uptake is important for biologically active or mobile contaminants; other contaminants unused or toxic to plants (e.g., plutonium) are discriminated against by biological systems, and their root uptake is minimal.

It is important to remember that the modeling of transfer of radionuclides from soils to plants is based entirely on empirical observation. For combinations of other plant and soil types that have not been directly observed, any factor used is at best an approximation. 


\subsection{Potential Non-Linear Uptakes}

A key assumption of the transfer-factor approach is that the transfer factor is a constant as a function of concentration; that is, the uptake is linear. This may not be true for contaminants that are nutrients or are chemical analogues for them. Non-linear responses may be possible if plants scavenge essential elements at low concentrations but maintain a homeostatic balance (i.e., an internal level regulated by the plant at optimal concentrations) at higher soil concentrations (Sheppard and Sheppard 1985). The assumption of linearity may be appropriate for elements that are not essential to biological function, are not analogues of such elements, or are not absorbed by organisms via nutrient pathways. These latter elements seldom exhibit linearity at very low environmental concentrations (Figure 2.1). For such elements (Table 2.1), organisms often are able to homeostatically regulate their tissue concentrations over a range of environmental concentrations. In some cases, these concentrations may be 40 to 200 times greater than the amount needed to sustain life (Förstner and Wittmann 1981). There is generally little information to evaluate this concept except for a few radionuclides such as cesium or strontium which are thought to biologically mimic potassium and calcium, respectively.

The differences in predicted effects between linear and homeostatic models can be substantial. Experience in assessing risks of metals in sediments and groundwater indicates that, for certain metals and species, the linear model can overestimate exposure by up to six orders of magnitude (DOE 1997).

To date, few models have been developed to deal with this problem. A possible alternative for radionuclides with this behavior would be to treat them with a specificactivity type model, wherein the atom ratio of the radioactive to stable atoms of an element are assumed to be the same in the plant as in the soil.

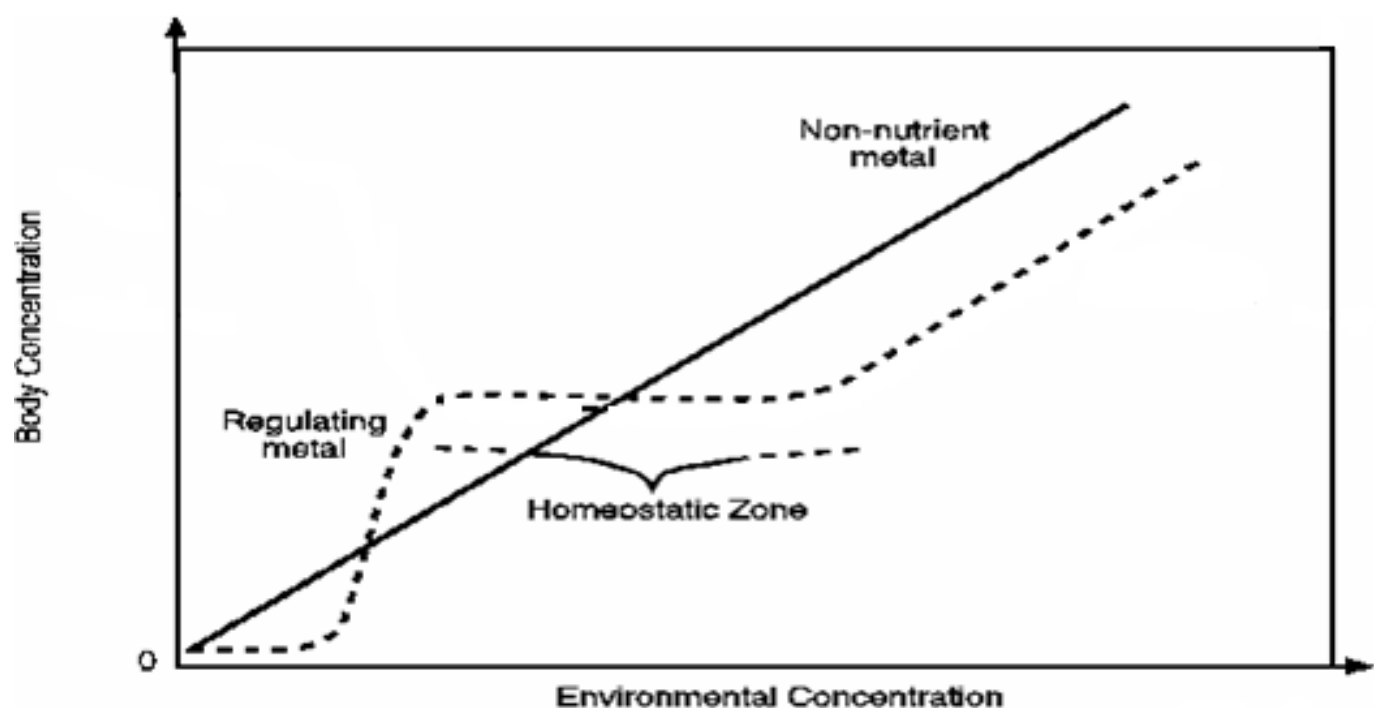

Figure 2.1. Relationships between Tissue Concentrations and Environmental Concentrations for Non-nutrient and Nutrient Compounds 
Table 2.1. A Biological Classification of Metals: Shaded Cells are Non-nutrient Analogs; Bold Cells are Nonessential Metals.

\begin{tabular}{||c|c|c|c|c|c|c|c|c|c||}
\hline Period & \multicolumn{2}{|c|}{ Macronutrient } & \multicolumn{5}{|c||}{ Micronutrient } & \multicolumn{2}{|c||}{ Non-essential } \\
\hline \hline 3 & $\mathrm{Na}$ & $\mathrm{Mg}$ & & & & & & & \\
\hline 4 & $\mathrm{~K}$ & $\mathrm{Ca}$ & $\mathrm{Cr}$ & $\mathrm{Mn}$ & $\begin{array}{c}\mathrm{Fe}, \\
\mathrm{Co}, \mathrm{Ni}\end{array}$ & $\mathrm{Cu}$ & $\mathrm{Zn}$ & & \\
\hline 5 & & $\mathrm{Sr}$ & & & & & $\mathrm{Cd}$ & & \\
\hline 6 & $\mathrm{Cs}$ & & & & & & & $\mathrm{Hg}$ & $\mathrm{Pb}$ \\
\hline 7 & & & & & & & & $\mathbf{E u}, \mathbf{U}$ & $\mathbf{N p}$ \\
\hline
\end{tabular}

(a) Period is from the Periodic Table of the Elements.

\subsection{Uptake in Fruit Trees}

The standard linear uptake model described above using transfer factors was originally developed for annual crops (leafy vegetables, root vegetables, forages, and grains). The vast majority of available observations, either laboratory or field studies, are for a limited number of crop types. In addition, observations are not available for all crop types for all chemical elements, and most compendiums of transfer factors use surrogates, relying on similar plant types, soil types, or chemical behavior to fill gaps in the knowledge (e.g., Staven et al. 2003; Yu et al. 2001).

The standard model is also used for perennial plants, including fruit trees. The model may not be appropriate for trees, considering their longer life and potential for accumulating contaminants in roots, trunks, and leaves, with transport to fruits possibly delayed for periods of over 1 year. The British Ministry of Agriculture, Fisheries, and Food (MAFF, since 2001 called the Department for Environment, Food, and Rural Affairs) has noted that such "models for fruit are extremely conservative... Extensive research is underway to produce more appropriate data. However, a review for MAFF concludes that no better fruit models currently exist" (MAFF 1999).

The International Union of Radioecologists and the International Atomic Energy Agency jointly prepared a major review of soil-to-plant transfer factors (IAEA 1994), which is used as a basic reference world-wide. In this review, soil-to-plant transfer factors are presented for many radionuclides and crop types. None of them refer to fruit or nut trees. A more recent compilation for tropical ecosystems does include some fruit trees (primarily apples), but the only nut is the coconut (Carini 2001). This state of affairs has been discussed in the international arena for several years; the IAEA's Validation of Model Predictions (VAMP) Program Multiple Pathways Assessment Working Group noted in the early 1990s that many participants overestimated concentrations of ${ }^{137} \mathrm{Cs}$ in fruit trees, and that models for predicting the contamination of fruit were in need of further improvement (IAEA 1995). The sequel to VAMP, the IAEA's Biosphere Modeling and Assessment (BIOMASS) Program, included a Fruits Working Group (IAEA 1996). As part of the work of the Fruits Working Group, a review was undertaken of the experimental, field and modeling information on the transfer of radionuclides to fruit. The 
results of this work were published as a special issue of the Journal of Environmental Radiation (Ventner et al. 2001).

In this special issue, Mitchell (2001) reports that there are three generic types of models that are applicable to fruit trees:

- Simple mathematical functions describing declining concentration in fruit, based on observations following deposition (e.g., Antonopoulos-Domis et al. 1990);

- Models that attempt to predict temporal distribution in soil-plant systems through descriptions of the processes involved; e.g. a model postulated by Frissell at the 1994 VAMP meeting in Vienna;

- Radiological dose assessment models that use a mixture of equilibrium and/or dynamic modeling approaches to predict concentrations in edible products; e.g. SPADE (Thorne and Coughtrey 1983).

Antonopoulos-Domis et al. (1990) developed a model structure for perennial fruit trees describing distribution, retention, transfer and rejection of radionuclides, based on experimental determinations of ${ }^{137} \mathrm{Cs}$ in apricot fruit trees. The original concept for the model was based on the fact that the leaves and fruits developing each year are only contaminated by a portion of the ${ }^{137} \mathrm{Cs}$ in the body of the tree. A fraction of this available reservoir is removed each year, part is lost from the tree through leaves and fruit and part becomes irretrievably associated with the body of the tree. This model requires knowledge of the contaminant inventory in the soil and the tree, as well as the deposition. The model is not immediately transferable to other types of trees, radionuclides, and locations, but it does indicate that at least two compartments are probably necessary to adequately describe the long-term accumulation and transfer of contaminants from trees into fruits.

A model for radiocesium transfer to tree fruit described by Frissel (1994) considers the homeostatic control of potassium within fruit trees. The model structure has four compartments and was designed to consider the long-term fate of cesium in soil as affected by changes in the supply of potassium to soil. The four compartments are soil, the easily accessible part of a tree, the poorly accessible woody part, and the fruit or leaf. The model is homeostatic; i.e., all cesium concentrations and fluxes are controlled by potassium concentrations and fluxes, respectively. In determining the various transfer parameters, it is assumed that there is no difference in the behavior of potassium and cesium, but that discrimination occurs between the compartments. The loss of plant material, termed debris by Frissel, via branches, leaf fall and fruit loss is included and returned to the soil, but because uptake is homeostatically controlled, this has minimal influence on the tree contents. Frissel (1994) concluded that the model was probably not sufficient to describe cesium transfer to fruit. In particular, the use of three compartments was not sufficient to model availability within the plant. The model results do indicate that important processes are likely to be the biological half time of cesium in wood, the discrimination between cesium and potassium, cycling of potassium (through falling leaves, etc.), and uptake of potassium.

The fruit plant model in the SPADE computer code (Thorne and Coughtrey 1983) has six compartments, representing internal leaf, external leaf, stem, fruit, storage organs and root. Movement of radionuclides within the plant model is controlled by empirically derived rate constants and parameters are derived for three broad categories of fruit plant: herbaceous, shrub and tree. Foliar absorption is represented by transfers between the external leaf and internal leaf compartments. Interception by plants takes account of 
changes in plant biomass with season. The original default parameters were based largely on data for cereals but were modified in the case of tree and shrub fruits to allow for more rapid transfer from stem to root so that the root store could serve as a reservoir through subsequent seasons. Loss of radionuclides from external plant surfaces to the soil is modeled as transfer to the surface layer of the soil model. The process of root uptake is modeled as the transfer of radionuclides from soil solution to the plant root compartment. The transfer rate is also assumed to vary with soil layer depth, both as a function of the root distribution throughout the soil profile and as a function of the deposit distribution in soil. Consequently, the transfer of radionuclides from the soil solution to root is represented by a discrete transfer from each of the 10 layers in the soil model. The soil solution to root rate constant in each soil layer is a function of the root uptake rate constant and the assumed distribution of root activity in each layer. Three plant absorption mechanisms are responsible for the transfer of radionuclides at the soil-root interface: plant-base absorption, main root system absorption and tap root absorption. The actual value of the soil solution to root transfer coefficient for each root layer corresponding to the soil layer of the soil model is calculated as the product of the specified rate coefficient and the normalized root shape modifier.

None of these models appears to be suitable for generic use in long-term radiological assessments without substantial modification and simplification, and all require additional development of parameters before general use. Again, it was noted that measurements of radionuclide uptake in trees were lacking (Carini 2001), and recommended that "There is a need for research on the behavior of radionuclides in fruit crops to drive model development, not simply to parameterize existing models. Research should focus on understanding the key processes" (Coughtrey et al. 2001). As a result of these recommendations, the IAEA initiated the Environmental Modeling for Radiation Safety (EMRAS) program in 2003. This program had a Working Group on Revision of IAEA Technical Report Series No. 364 "Handbook of Parameter Values for the Prediction of Radionuclide Transfer in Temperate Environments" and attempted to establish another Fruits Working Group. However, the participation in the Fruits group was so low that these participants joined with the Handbook group.

The IAEA handbook has recently been issued as Technical Reports Series Number 472 (IAEA 2009), supported with a larger compendium (IAEA 2010). These documents indicate that there remains a paucity of information about radionuclide uptake in fruits. 



\subsection{SAMPLING AND ANALYSIS OF SOIL AND FRUIT SAMPLES}

Soil and vegetation samples were collected from a single farm in southern Nevada growing a wide variety of crops of interest. The soil samples were collected for use in plant radionuclide uptake studies. The information on soil in this section is a replication of that originally reported in Napier et al. (2005) so that the soil and transfer factor information could be easily found within a single reference.

The farm has been used for exploratory cultivation of a wide variety of tree species and other food crops. Standing crops include pistachio, almond, fig, carob, alfalfa, grapes, apples, pomegranate, pecan, field oats, apricots, and nectarines. All are irrigated from the underlying aquifer, using surface irrigation (not overhead sprinklers), and are registered as organic farm products (no pesticides or refined fertilizers). A sampling trip was taken to collect soil cores and up to six replicates of leaves, stems, and fruits of alfalfa, almond, apple, apricot, carob, fig, grape, nectarine, oats, pecan, pistachio, and pomegranate.

In addition to the soil and vegetation, samples were also taken of local groundwater used for irrigation and 1:1 soil-water extracts. Because these water samples were generally determined to have concentrations of materials too low for use in generation of transfer factors, they are not further discussed in this report.

\subsection{Sampling and Analysis of Soil Samples}

Uncontaminated soil samples were collected. The latitude and longitude position of each sampling location was recorded by using a global positioning system (GPS) unit to provide traceability and the opportunity to provide duplicate samples if required.

The sampling site is located in Nye County, Nevada, in a desert valley approximately 110 miles west of Las Vegas in the Amargosa Valley. The soil samples were collected from private land. The farmland was used to grow alfalfa for about 14 years up until about 1996, when it was allowed to turn to pasture. According to the land owner, the soil was originally conditioned using approximately 10 tons/acre of gypsum. No commercial fertilizer was used on the pasture. The soil was approximately 2.5 feet thick at the sample site, and consists of a light brown silty sand. Near the base, the occurrence of white streaks (calcareous materials) in the soil increased until the soil transitioned into broken-up calcrete.

\subsubsection{Characterization and Analysis of Bulk Soil Samples}

Detailed information about the soil is provided here, to provide background information for future researchers. In the following tables, analyses are listed for primary and duplicate samples. A duplicate sample is selected at random when a set of samples is submitted for analyses as part of the standard laboratory quality-assurance operating procedures used by the analytical laboratories in the PNNL Applied Geology and Geochemistry Group. 


\subsubsection{X-ray Diffraction}

The primary crystalline minerals present in each bulk soil sample were identified using a Scintag X-ray powder diffraction (XRD) unit equipped with a Pelter thermoelectrically cooled detector and a copper X-ray tube. The diffractometer was operated at $45 \mathrm{kV}$ and $40 \mathrm{~mA}$. Individual scans were obtained from 2 to $65^{\circ} 2 \theta$ with a dwell time of 2 seconds. Scans were collected electronically and processed using the $\mathrm{JADE}^{\circledR} \mathrm{XRD}$ pattern-processing software. Identification of the mineral phases in the background-subtracted patterns was based on a comparison of the XRD patterns measured for the samples with the mineral powder diffraction files (PDF TM) published by the Joint Committee on Powder Diffraction Standards (JCPDS) International Center for Diffraction Data (ICDD).

The background-subtracted XRD patterns for the soil sample are shown in Figure 3.1. Each XRD pattern is shown as a function of degrees $2 \theta$ based on $\mathrm{Cu} \mathrm{K}$ radiation $(\lambda=1.5406 \AA)$. The vertical axis in each pattern represents the intensity in counts per second (cps) of the XRD peaks. In order to conveniently scale the XRD patterns on the vertical axes and visualize the minor XRD peaks, it was necessary to cutoff the intensity of the most intense XRD peak in each pattern. These intensity cutoffs are labeled on each XRD pattern, and correspond to the largest XRD peak for quartz.

At the bottom of the XRD pattern, schematic database PDF patterns considered for phase identification are also shown for comparison purposes. The height of each line in the schematic PDF patterns represents the relative intensity of an XRD peak (i.e., the most intense [the highest] peak has a relative intensity $\left[\mathrm{I} / \mathrm{I}_{\mathrm{o}}\right]$ of $100 \%$ ). As noted previously, a crystalline phase typically must be present at greater than $5 \mathrm{wt} \%$ of the total sample mass (greater than $1 \mathrm{wt} \%$ under optimum conditions) to be readily detected by XRD.

The following minerals were identified in the soil sample: quartz, plagioclase feldspar, microcline feldspar, amphibole, zeolite, and mica. More detailed analyses would be required to refine the identities of the general mineral identifications (e.g., plagioclase, amphibole, zeolite, mica, etc.) to specific compositions. The soil sample appears to contain a zeolite mineral. Although the pattern for this soil sample (Figure 3.1) was a good match to the database pattern for clinoptilolite (PDF 47-1870), other compositions of zeolites may also match this pattern.

\subsubsection{Elemental Analysis by X-ray Fluorescence}

Elemental analysis of the bulk soil samples was determined by X-ray fluorescence (XRF). The XRF analyses were completed for PNNL by staff at the GeoAnalytical Laboratory in the Department of Geology at Washington State University using a Thermo-ARL Advant' XP+ automated spectrometer. The sequential, wavelength dispersive spectrometer contains a Rhtarget X-ray tube operated at $60 \mathrm{kV}, 60 \mathrm{~mA}$. Samples were prepared for XRF analysis using a lithium tetraborate flux fusion method which includes double fusing (for homogeneity) in carbon crucibles at $1000^{\circ} \mathrm{C}$. Preparation time and analytical time were both approximately one hour per sample. Except for now using diamond-impregnated metal disks to improve the lapping of specimen surfaces to flatness, the details of sample preparation are essentially those described in Johnson et al. (1999). Concentrations of major constituents are provided in Table 3.1; concentrations of trace elements are listed in Table 3.2. 


\subsubsection{Particle Size Distribution}

American Society for Testing and Materials (ASTM) procedures ASTM D1140-00 (ASTM 2000) and D422-63 (ASTM 2003) were used for particle size analysis of the soil samples. In ASTM D422-63, a sedimentation process using a hydrometer is used to determine the distribution of particle sizes smaller than $75 \mu \mathrm{m}$, while sieving was used to measure the distribution of particle sizes larger than $53 \mu \mathrm{m}$ (retained on a No. 270 sieve). A No. 10 sieve, which has sieve size openings of $2.00 \mathrm{~mm}$, was first used to remove the fraction larger than "very coarse" prior to particle size analysis. Particle size results are shown in Table 3.3; the soil is essentially $99 \%$ sand.

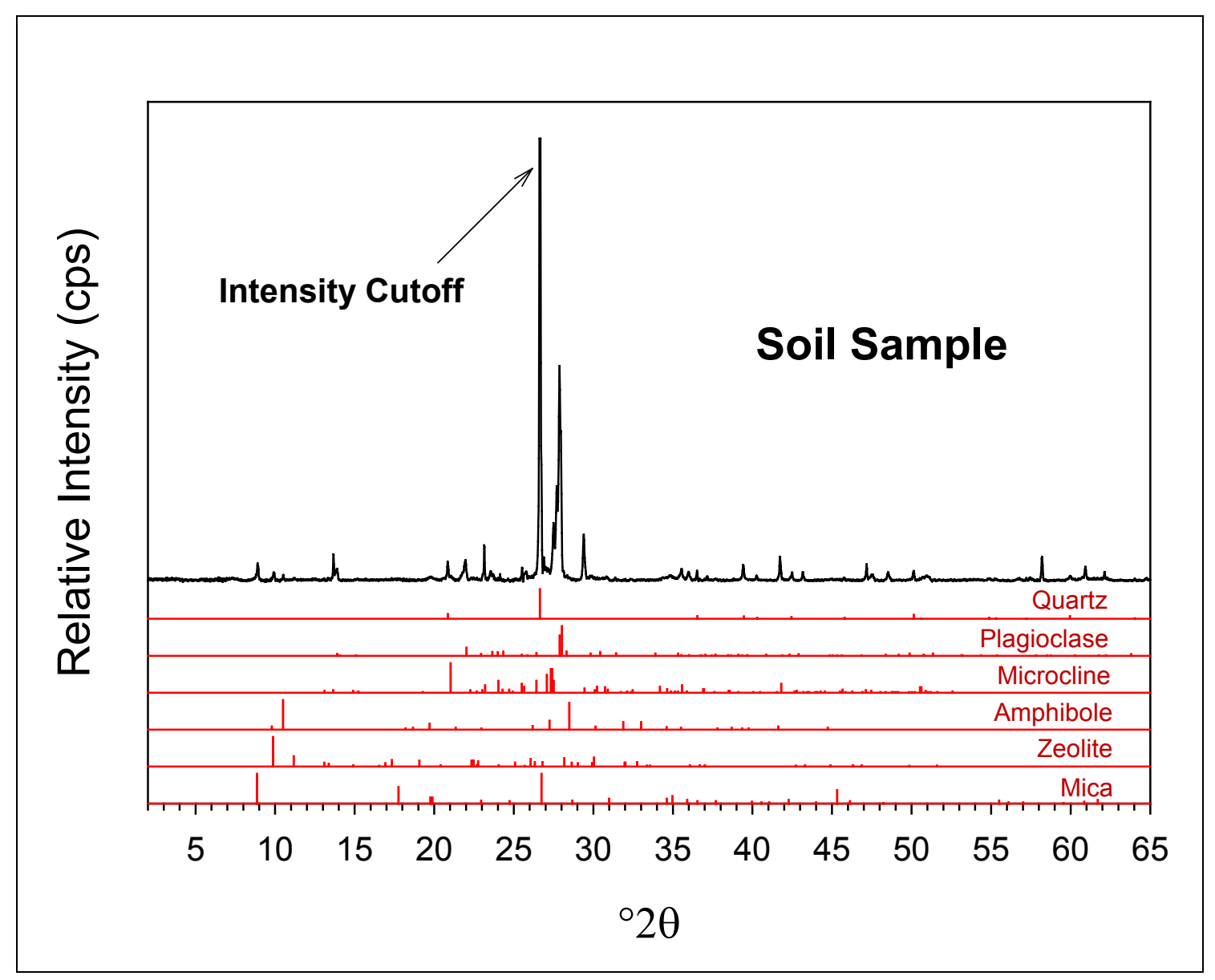

Figure 3.1. Background-Subtracted XRD Pattern for Nye County Soil Sample 
Table 3.1. Concentrations of Major Elements in Bulk Soil Samples as Determined by XRF

\begin{tabular}{|c|c|c|c|c|c|c|c|c|c|c|}
\hline $\mathrm{Al}_{2} \mathrm{O}_{3}$ & $\mathrm{CaO}$ & $\mathrm{FeO}^{*}$ & $\mathrm{~K}_{2} \mathrm{O}$ & MgO & $\mathrm{MnO}^{* *}$ & $\mathrm{Na}_{2} \mathrm{O}$ & $\mathrm{P}_{2} \mathrm{O}_{5}$ & $\mathrm{SiO}_{2}$ & $\mathrm{TiO}_{2}$ & Total \\
\hline \multicolumn{11}{|c|}{ (wt $\%$ - dry basis, normalized to $100 \%$ ) } \\
\hline 13.44 & 6.23 & 2.04 & 4.31 & 1.55 & 0.064 & 3 & 0.071 & 68.95 & 0.347 & 100 \\
\hline \multicolumn{11}{|c|}{$\begin{array}{l}\text { Concentrations of total iron are normalized to FeO. XRF determines the concentrations of } \\
\text { total iron and manganese, but does not provide any data regarding the oxidation states of such } \\
\text { redox sensitive elements present in the sample. } \\
{ }^{* \star} \text { Concentrations of total manganese are normalized to } \mathrm{MnO} \text {. }\end{array}$} \\
\hline
\end{tabular}

Table 3.2. Concentrations of Trace Elements in Bulk Soil Samples as Determined by XRF

\begin{tabular}{|r|r|r|r|r|r|r|r|r|r||}
\hline Ba & Ce & Cr & Cu & Ga & La & Nb & Nd & Ni \\
\hline \multicolumn{7}{|c|}{$(\mathbf{p p m})$} \\
\hline \hline 694 & 95 & 13 & 9 & 17 & 53 & 19 & 36 & 10 \\
\hline \hline $\mathbf{P b}$ & $\mathbf{R b}$ & $\mathbf{S c}$ & $\mathbf{S r}$ & $\mathbf{T h}$ & $\mathbf{V}$ & $\mathbf{Y}$ & $\mathbf{Z n}$ & $\mathbf{Z r}$ \\
\hline \multicolumn{7}{|c|}{$\mathbf{( p p m )}$} \\
\hline 24 & 136 & 6 & 413 & 19 & 24 & 27 & 53 & 256 \\
\hline
\end{tabular}

Table 3.3. Particle Size Analysis of the Bulk Soil Samples

\begin{tabular}{|c|c|c|}
\hline $\begin{array}{c}\text { Gravel } \\
(\mathbf{x}>\mathbf{2} \mathbf{~ m m})\end{array}$ & $\begin{array}{c}\text { Sand } \\
(\mathbf{2}>\mathbf{x}>\mathbf{0 . 0 5 0} \mathbf{m m})\end{array}$ & $\begin{array}{c}\text { Silt/Clay } \\
(\mathbf{x}<\mathbf{0 . 0 5 0} \mathbf{m m})\end{array}$ \\
\hline \multicolumn{3}{|c|}{$(\mathbf{w t} \%)$} \\
\hline 0.0 & 98.99 & 1.01 \\
\hline
\end{tabular}




\subsubsection{Moisture Content}

Gravimetric water contents of the soil samples were determined using PNNL procedure PNLMA-567-DO-1 (PNL 1990). ${ }^{1}$ This procedure is based on the ASTM Method D2216-98 (ASTM 1998). One representative subsample of each soil sample was placed in tared containers, weighed, and dried in an oven at $105^{\circ} \mathrm{C}\left(221^{\circ} \mathrm{F}\right)$ until constant weight was achieved, which took at least 24 hours. The containers then were removed from the oven, sealed, cooled, and weighed. Two weighings, each after a 24-hour heating, were performed to ensure that all moisture was removed. The gravimetric water content shown in Table 3.4 was computed as the percentage change in soil weight before and after oven drying.

Table 3.4. Moisture Contents of the Bulk Soil Samples

\begin{tabular}{||l|c|c|}
\hline \multirow{2}{*}{ Soils } & \multicolumn{2}{c|}{ Moisture (wt\%) } \\
\cline { 2 - 3 } & $\begin{array}{c}\text { First } \\
\text { Weighing }\end{array}$ & $\begin{array}{c}\text { Second } \\
\text { Weighing }\end{array}$ \\
\hline Primary & 2.51 & 2.30 \\
\hline Duplicate & 2.57 & 2.38 \\
\hline
\end{tabular}

\subsubsection{Cation Exchange Capacity}

The cation exchange capacity (CEC) of each of the soil samples was determined using the method described in American Society of Agronomy (ASA) (1982). This method is particularly suited to arid land soils, including those containing carbonate, gypsum, and zeolites. This procedure involves two steps. The first step consists of saturation of the cation exchange sites with $\mathrm{Na}$ by reaction of the soil with $\mathrm{pH} 8.2,60 \%$ ethanol solution of $0.4-\mathrm{N} \mathrm{NaOAc}-0.1 \mathrm{~N} \mathrm{NaCl}$. This is then followed by extraction of $0.5 \mathrm{~N} \mathrm{MgNO}_{3}$. The concentrations of dissolved $\mathrm{Na}$ and $\mathrm{Cl}$ are then measured in the extracted solution so that the dissolved $\mathrm{Na}$ from the excess saturation solution, carried over from the saturation step to the extraction step, is deducted from the total $\mathrm{Na}$. This provides the amount of exchangeable $\mathrm{Na}$, which is equivalent to the CEC. Results for three replicates are shown in Table 3.5.

Table 3.5. Cation Exchange Capacity (CEC) Values for the Soil Samples

\begin{tabular}{|c|c|c|c|}
\hline \multicolumn{4}{|c||}{ CEC (meq/100 g) } \\
\hline$\# 1$ & $\# 2$ & $\# 3$ & Average \\
\hline 27.3 & 28.5 & 29.3 & 28.4 \\
\hline
\end{tabular}

1 PNL. 2000. "PNNL Technical Procedure SA-7. Water Content." Procedure approved in May 2000, in Procedures for Ground-Water Investigations, PNL-MA-567, Pacific Northwest National Laboratory, Richland, Washington. 


\subsubsection{Carbon Content}

The total carbon and the inorganic carbon contents of the soil samples were measured using a Shimadzu Carbon Analyzer Model TOC-V csn. The method used to measure the carbon contents of the soil samples is similar to ASTM Method E1915-01 (ASTM 2001). Known quantities of calcium carbonate standards were analyzed to verify that the instrumentation was operating properly. Inorganic carbon content was determined through calculations performed using the microgram per-sample output data and sample weights. The organic carbon content of the soil samples was calculated by subtracting the inorganic carbon contents from the respective total carbon contents for each sample. Results are shown in Table 3.6.

Table 3.6. Carbon Contents of the Soil Samples

\begin{tabular}{|c|c|c|c|c|c|c|c|c|}
\hline \multirow[t]{3}{*}{ Soil } & \multicolumn{3}{|c|}{ Total Carbon } & \multicolumn{3}{|c|}{$\begin{array}{c}\text { Total Inorganic } \\
\text { Carbon }\end{array}$} & \multirow{2}{*}{$\begin{array}{c}\text { Total } \\
\text { Inorgani } \\
\text { c } \\
\text { Carbon } \\
\text { As } \\
\mathrm{CaCO}_{3} \\
\text { Ave }\end{array}$} & \multirow{2}{*}{$\begin{array}{c}\begin{array}{c}\text { Total } \\
\text { Organic } \\
\text { Carbon } \\
\text { (by } \\
\text { difference) }\end{array} \\
\text { Ave }\end{array}$} \\
\hline & \#1 & \#2 & Ave & $\# 1$ & \#2 & Ave & & \\
\hline & \multicolumn{8}{|c|}{ (wt\%) } \\
\hline Primary & 1.10 & 1.08 & 1.09 & 0.97 & 0.98 & 0.97 & 8.11 & 0.12 \\
\hline Duplicate & 1.38 & 1.38 & 1.38 & 1.26 & 1.22 & 1.24 & 10.31 & 0.14 \\
\hline
\end{tabular}

\subsection{Sampling and Analysis of Crop and Fruit Samples}

Up to six replicates were collected of leaves, stems, and fruits of alfalfa, almond, apple, apricot, carob, fig, grape, nectarine, oats, pecan, pistachio, and pomegranate. The sampled plants are shown in Figures 3.2 and 3.3.

The samples were collected July of 2004 at the farm, placed in paper bags, and shipped overnight to the Pacific Northwest National Laboratory. They were then unpacked, a fresh weight taken, the samples transferred to tared glass jars, and dried at $80^{\circ} \mathrm{C}$ for $72-$ to $96-\mathrm{h}$. Dry weights were then taken and the samples stored at room temperature in the closed jars.

The dried samples were then ground with a Wiley Mill (Sargent Welch, Inc. Philadelphia, PA) to a 20 mesh size. The samples were again stored at room temperature.

\subsubsection{Methods for Analysis of Vegetation Samples}

The primary interest was to obtain information about the concentrations of as many constituent elements in as many samples as possible, within budgetary constraints. Some initial range finding efforts were undertaken with mass spectrometry, these were followed up by a larger analysis using neutron activation analysis. 


\subsubsection{Mass Spectrometry}

Based on soil sampling results, a small range finding effort was made to obtain leaf and fruit/nut concentrations for selected stable analogue and other specific chemical elements. This range finding was based on single replicates of those fruit and nut species for which both leaves and fruit/nuts were available. The elements selected for Induction-Coupled Argon Plasma Mass Spectrometry (ICAP) analysis were Cs, Co (+2, 3), Ga (+3 ion), I, Mg (+2 ion), Ni, P (+3, 5, -3), Se $(+4,6,-2), \mathrm{Ag}(+1)$ and Sr. Selected samples (10-g aliquots) were sent to Huffman Labs, Inc. (Golden, Colorado) for wet digestion and ICAP analysis. The results are given in Table 3.7. These results verify the neutron activation analysis results discussed in Section 3.2.1.2; they were not used in the derivation of the transfer factors.

Table 3.7 Elemental Results from ICAP-MS analysis.

\begin{tabular}{|c|c|c|c|c|c|c|c|}
\hline $\begin{array}{c}\text { Element } \\
(\mu \mathrm{g} / \mathrm{g})\end{array}$ & $\begin{array}{c}\text { Alfalfa } \\
\text { Leaf/Stem }\end{array}$ & $\begin{array}{c}\text { Almond } \\
\text { Leaf }\end{array}$ & $\begin{array}{c}\text { Almond } \\
\text { Fruit }\end{array}$ & $\begin{array}{l}\text { Apple } \\
\text { Leaf }\end{array}$ & Apple Fruit & $\begin{array}{c}\text { Apricot } \\
\text { Leaf }\end{array}$ & $\begin{array}{l}\text { Apricot } \\
\text { Fruit }\end{array}$ \\
\hline$\overline{C \text { Cs }}$ & 0.02 & 0.079 & 0.029 & 0.059 & 0.005 & $=0.058$ & 0.046 \\
\hline Co & 0.13 & 0.15 & 0.05 & 0.12 & 0.01 & 0.11 & 0.07 \\
\hline $\mathrm{Ga}$ & 0.03 & 0.12 & 0.05 & 0.11 & 0.02 & 0.1 & 0.09 \\
\hline 1 & 0.3 & 0.4 & 0.5 & 0.4 & $<0.5$ & 1 & 0.9 \\
\hline $\mathrm{Mg}$ & 2630 & 5940 & 1260 & 2850 & 481 & 3430 & 877 \\
\hline $\mathrm{Ni}$ & 1.5 & 1.5 & 5.7 & 2.4 & 3.2 & 0.6 & 2.3 \\
\hline$P$ & 212 & 903 & 1840 & 1350 & 945 & 2700 & 2640 \\
\hline $\mathrm{Se}$ & 0.12 & 0.13 & 0.11 & 0.09 & $<0.05$ & 0.07 & 0.06 \\
\hline $\mathrm{Ag}$ & 0.02 & 0.03 & $<0.01$ & 0.01 & 0.01 & 0.02 & $<0.01$ \\
\hline $\mathrm{Sr}$ & 107 & 117 & 14 & 81 & 1.9 & 91 & 6.8 \\
\hline $\begin{array}{c}\text { Element } \\
(\mu \mathrm{g} / \mathrm{g})\end{array}$ & $\begin{array}{c}\text { Carob } \\
\text { Leaf }\end{array}$ & $\begin{array}{c}\text { Carob } \\
\text { Fruit }\end{array}$ & Fig Leaf & Fig Fruit & $\begin{array}{l}\text { Grape } \\
\text { Leaf }\end{array}$ & $\begin{array}{c}\text { Grape } \\
\text { Fruit }\end{array}$ & $\begin{array}{c}\text { Oat } \\
\text { Leaf/Seed }\end{array}$ \\
\hline Cs & 0.066 & 0.014 & 0.095 & 0.009 & 0.059 & 0.014 & 0.012 \\
\hline Co & 0.14 & 0.04 & 0.19 & 0.36 & 0.16 & 0.03 & 0.13 \\
\hline $\mathrm{Ga}$ & 0.11 & 0.04 & 0.16 & 0.03 & 0.12 & 0.04 & 0.04 \\
\hline I & 1 & 1.3 & 0.7 & 0.3 & 1.3 & $<0.5$ & 0.3 \\
\hline $\mathrm{Mg}$ & 1840 & 1010 & 4380 & 1620 & 3760 & 1250 & 1610 \\
\hline $\mathrm{Ni}$ & 1.4 & 1.8 & 1.9 & 1.8 & 0.7 & 0.2 & 3 \\
\hline$P$ & 1520 & 1810 & 1260 & 1660 & 3640 & 2350 & 2230 \\
\hline $\mathrm{Se}$ & 0.14 & 0.06 & 0.19 & 0.06 & 0.12 & $<0.05$ & 0.08 \\
\hline $\mathrm{Ag}$ & 0.01 & $<0.01$ & 0.02 & $<0.01$ & $<0.01$ & $<0.01$ & $<0.01$ \\
\hline $\mathrm{Sr}$ & 126 & 24 & 153 & 42 & 160 & 21 & 14 \\
\hline
\end{tabular}




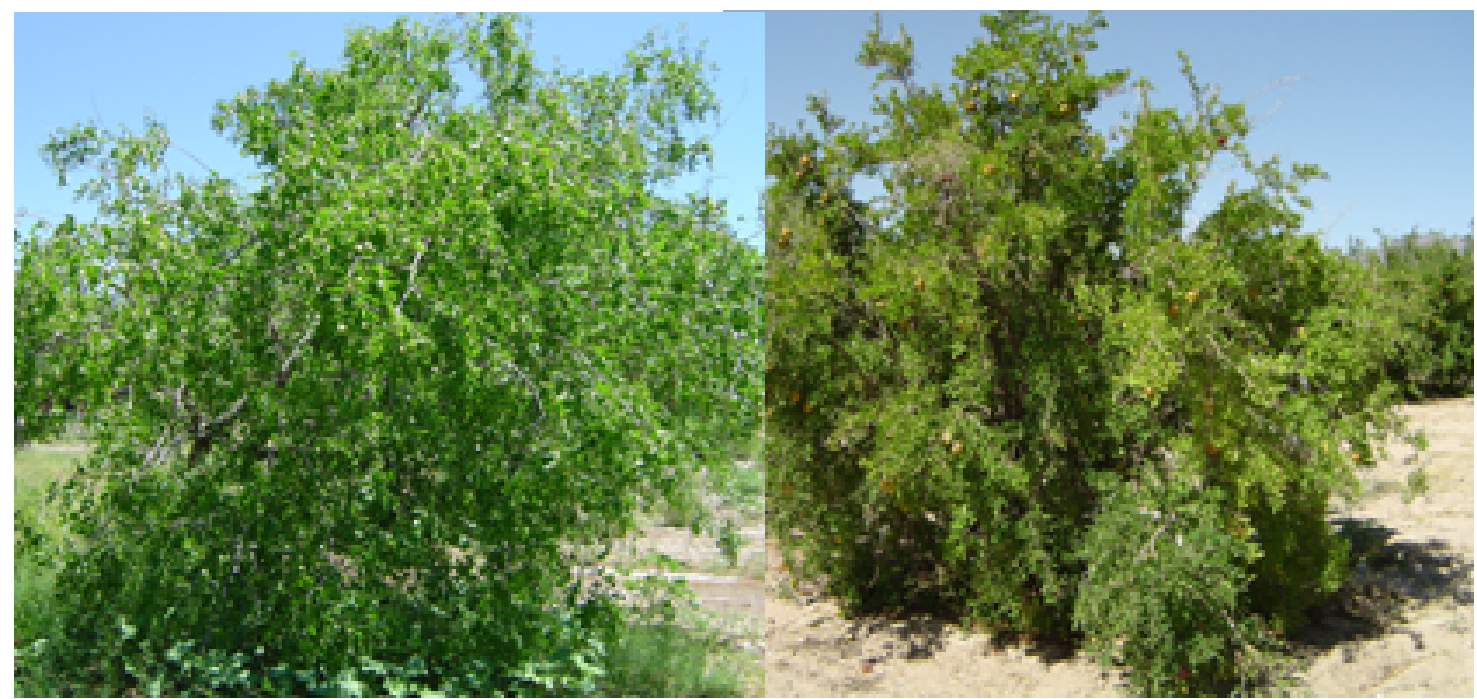

Grafted Pistachio

Natural Pistachio

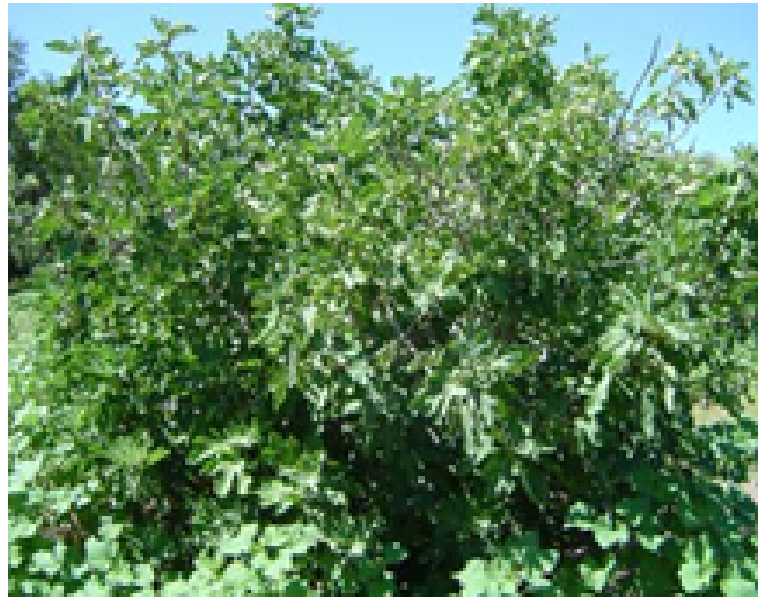

Fig

Figure 3.2. Plants Sampled - Grafted and Natural Pistachio, Fig. 


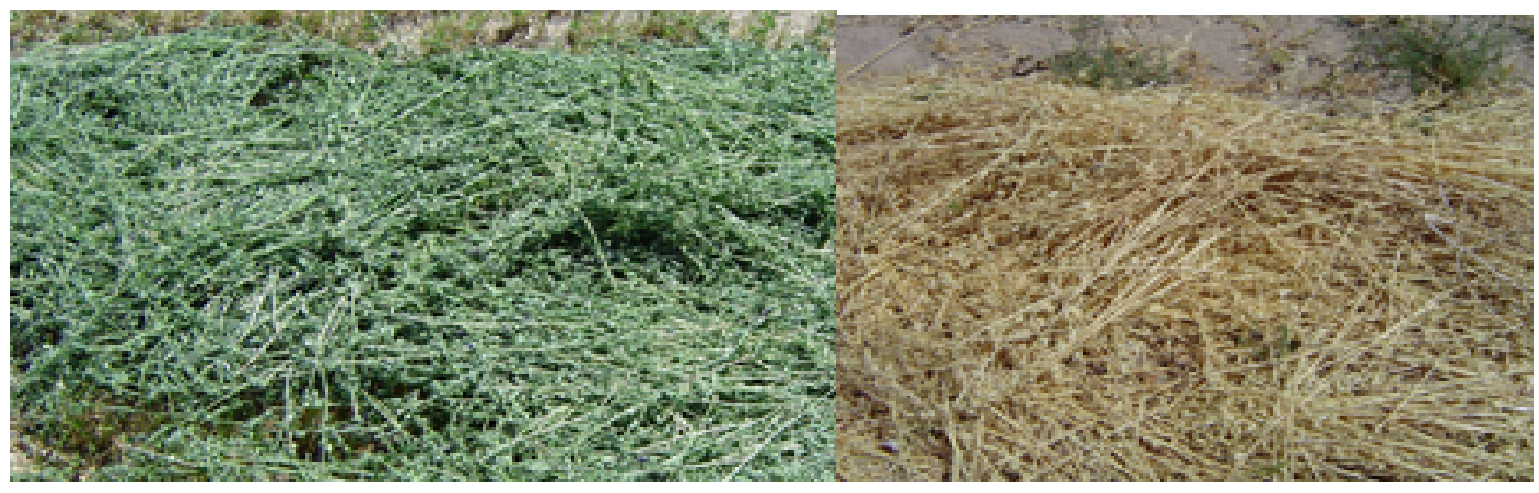

Alfalfa

Field Oat

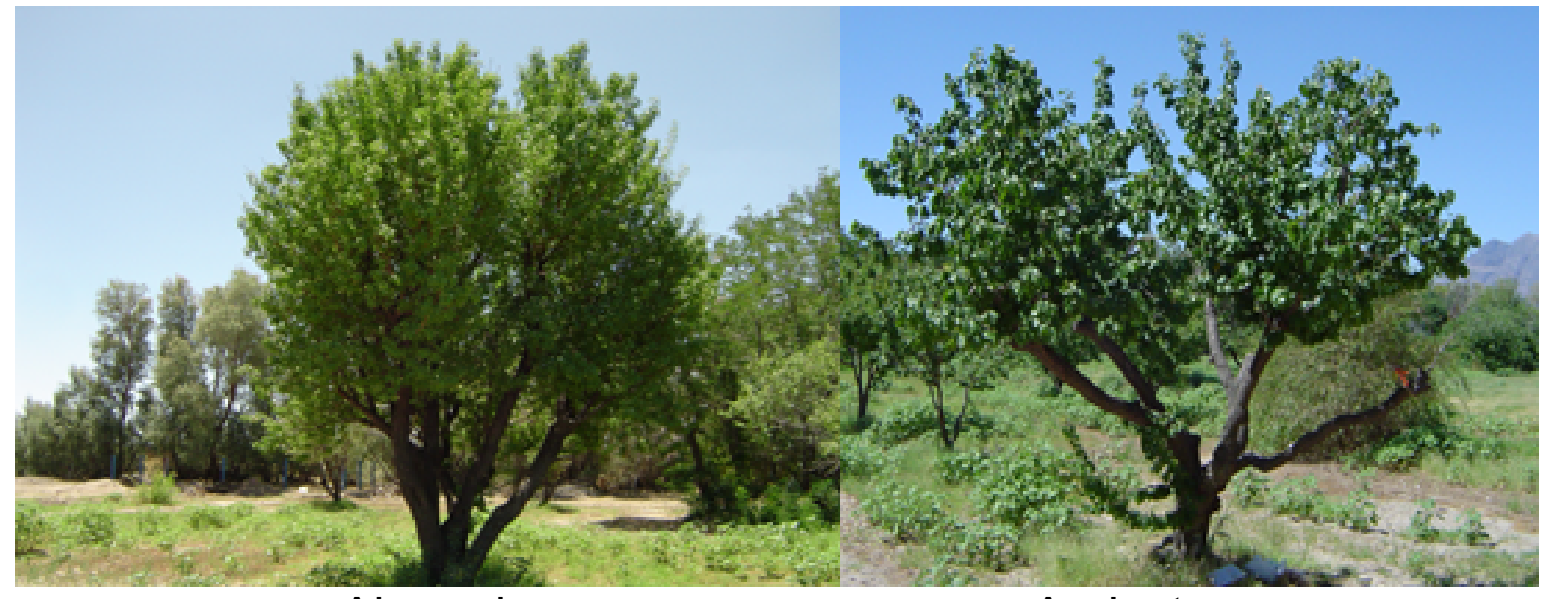

Almond

Apricot

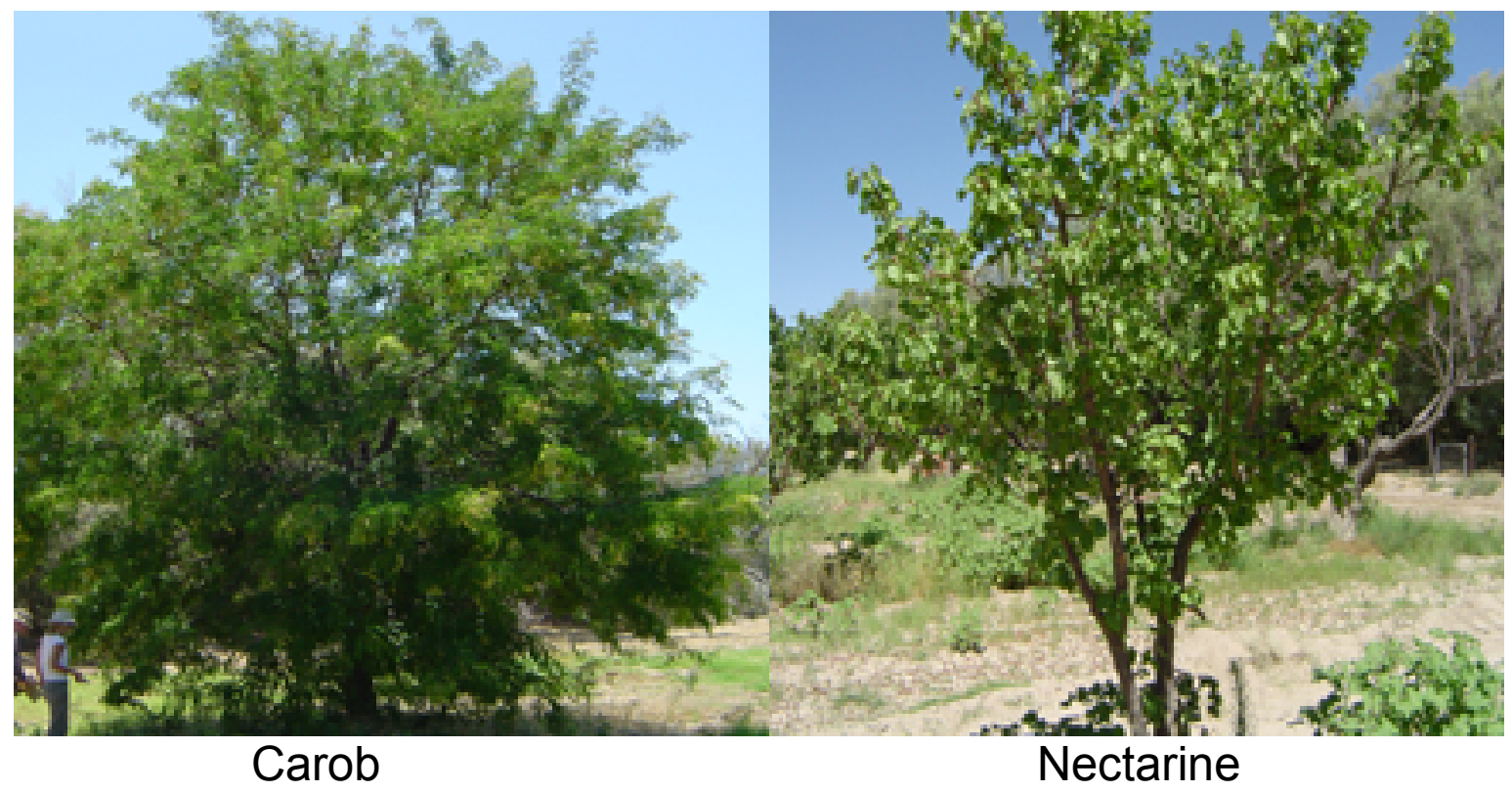

Figure 3.3. Plants Sampled - Field Crops Alfalfa and Oats, Fruits and Nuts Almond, Apricot, Carob, and Nectarine. 


\subsubsection{Instrumental Neutron Activation Analysis}

A total of 93 botanical samples (tree branches, tree leaves, and tree fruit/nuts for several types of trees, along with samples of alfalfa and oats) were evaluated by instrumental neutron activation analysis (INAA) at the Radiation Center at Oregon State University. Neutron activation analysis is a non-destructive, highly precise and accurate analytical technique capable of determining up to 48 elements in almost all types of sample matrices. The INAA procedure involves irradiating the samples and appropriate standard reference materials with neutrons to produce unstable radioactive nuclides. Many of these radionuclides emit gammarays with characteristic energies that can be measured utilizing high-resolution semiconductor detectors. The rate that the gamma-rays are emitted from an element in the sample is directly proportional to its concentration. Detection limits are in the parts per million to parts per billion range depending on the element and sample matrix. Three aliquots of soil were also included.

Standard multi-element trace-element analysis typically includes three suites of elements: those with very short half-lives (ranging from minutes to less than about 15 hours), those with intermediate half-lives (15 hours to several days), and those with long half-lives (on the order of several weeks to years). Effective characterization therefore requires a minimum of two irradiations, each followed by several counts of resultant gamma activity. These protocols are tailored to the type of material and the overall sample activity expected, and thus differ between botanical and soil samples.

Botanical Samples. Botanical samples have notoriously low concentrations of many elements, and thus are a challenge for multi-element analysis. One common solution is to dry ash the materials in order to reduce both the mass and volume of organic compounds and preconcentrate other elements, resulting in increased analytical sensitivity (Harju et al. 2004; Koh et al. 1999). However, a number of elements of interest - including $\mathrm{Br}$ and $\mathrm{Cl}$ - are highly volatile and can be lost in the ashing process. The solution advanced here was to analyze both unashed material and ashed materials, for different suites of elements as appropriate.

To dry ash the samples, approximately $5-25 \mathrm{~g}$ of plant material (depending on availability) was placed in a covered porcelain crucible, and heated to $550^{\circ} \mathrm{C}$ in a muffle furnace, using a slow ramp of about $200^{\circ} \mathrm{C}$ per hour and a soak time of 20 hours. As soon as samples were cool enough to handle, the ash was lightly ground and homogenized using a ceramic mortar and pestle, and transferred to tightly-capped liquid scintillation vials to prevent re-hydration. Concentration factors were determined from the ratio of pre-fire to post-fire mass, and used to determine the equivalent mass of unashed plant material that was irradiated. The standard reference material NIST1571 (orchard leaves) was similarly subjected to the ashing process, and both ashed and unashed aliquots of this standard reference material were included in the analysis to track the effects of ashing on element concentrations.

Analyses of elements analyzed via short half-life isotopes utilized unashed plant material. Approximately $700-850 \mathrm{mg}$ of sample plant material was packed into high-purity polyethylene $4 / 5 \mathrm{D}$ vials, weighed to the neared $0.1 \mathrm{mg}$, and then heat-sealed to ensure closure. Samples were irradiated for $60 \mathrm{~s}$ at $1 \mathrm{MW}_{\text {th }}$ using the OSU TRIGA reactor pneumatic tube system, which delivers samples to an in-core location with a thermal flux of $10^{13} \mathrm{n} \mathrm{cm}^{-2} \cdot \mathrm{s}^{-1}$. Following a decay of 14 minutes, each sample was then placed on a $25 \%$ relative efficiency HPGe detector at a distance of $14 \mathrm{~cm}$ from the detector face. Gamma activity was recorded for a period of $500 \mathrm{~s}$ (real time). 
Element concentrations were determined using the direct comparison method, with values calculated on a weight ratio basis relative to activities obtained in the standard reference material NIST1571 (orchard leaves). Three replicates of NIST1571 were included with every batch of 20-25 samples; a fourth replicate of NIST1571 was included in each batch as a checkstandard and treated as an unknown, in order to evaluate precision and accuracy of results. All data reductions were based on consensus values for the standard reference materials as reported in Glascock 2006 (Appendix B). These protocols resulted in data on concentrations of $\mathrm{Al}, \mathrm{Br}, \mathrm{Ca}, \mathrm{Cl}, \mathrm{Cu}, \mathrm{Dy}, \mathrm{K}, \mathrm{Mg}, \mathrm{Mn}, \mathrm{Na}, \mathrm{Ti}$, and V. However, $\mathrm{Cu}$ and Ti were consistently below detection limits in the NIST1571 standards, resulting in missing data for these elements in the botanical samples.

Dry-ashed material was utilized for analysis of elements determined through longer half-life isotopes. Ashed materials were encapsulated as above in high-purity polyethylene vials. In this case, encapsulated sample masses ranged from 0.5 to $1.0 \mathrm{~g}$ of ashed material, a range equivalent to $2-18 \mathrm{~g}$ of unashed material, depending on the concentration factor. The materials were organized in batches of ca. 25 samples, and subjected to a 21-hr irradiation in the rotating rack of the OSU TRIGA reactor, a location which experiences a nominal thermal neutron flux of $3 \times 10^{12} \mathrm{n} \mathrm{cm}^{-2} \mathrm{~s}^{-1}$. Two separate counts of gamma activity were made using a $32-38 \%$ relative efficiency detector, and a counting geometry of 3 inches. The first count of $5000 \mathrm{~s}$ (live-time) began 5 days after the end of irradiation, while the second count for 15,000 s followed a 4-week decay. These two counts provided data on As, Ba, La, Lu, K, Na, Sm, U, Yb, and Ce, Co, Cr, $\mathrm{Cs}, \mathrm{Eu}, \mathrm{Fe}, \mathrm{Hf}, \mathrm{Nd}, \mathrm{Rb}, \mathrm{Sb}, \mathrm{Sc}, \mathrm{Ta}, \mathrm{Tb}, \mathrm{Th}, \mathrm{Zn}$, and $\mathrm{Zr}$, respectively.

As above, element concentrations were determined via the direct comparison method. Three replicates of the standard reference material NIST1633a (coal fly ash) were included as standards. All data reductions were based on consensus values for the standard reference materials as reported in Glascock (2006). NIST1571 (orchard leaves) and NIST1570 (spinach) were included as check standards to verify accuracy and precision of results.

Soil Samples. Soils were irradiated and analyzed using standard protocols for the analysis of mineral samples. Approximately $250 \mathrm{mg}$ of material was placed in a $400 \mu \mathrm{L}$ polyvial, weighed to the nearest $0.1 \mathrm{mg}$, and then heat-sealed to ensure closure. The samples were then subjected to two irradiations, both followed by two separate counts of gamma activity. In this case, the data for short half-live isotopes ( $\mathrm{Al}, \mathrm{Ca}, \mathrm{Cu}, \mathrm{Ti}, \mathrm{V}, \mathrm{K}, \mathrm{Mn}, \mathrm{Na}$ ) result from a $7 \mathrm{~s}$ irradiation delivered via pneumatic tube to an in-core location with an average thermal flux of $10^{13}$ $\mathrm{n} \mathrm{cm}^{-2} \mathrm{~s}^{-1}$. Two separate counts were necessary, one after a 15-minute decay (for $\mathrm{Al}, \mathrm{Br}, \mathrm{Ca}$, $\mathrm{Cu}, \mathrm{Ti}$, and $\mathrm{V}$ ) using a $28 \%$ relative efficiency HPGe detector, and a second count after 2 -hr decay (for $\mathrm{K}, \mathrm{Mn}$, and $\mathrm{Na}$ ) on a $38 \%$ relative efficiency HPGe detector. Both counts were for 540 seconds (real time).

The concentrations of most elements were determined based on comparison with three replicates of the standard reference material NIST1633A (coal fly ash). In addition, the determination of Ca content was based on NIST688 (basalt rock), while Br content was evaluated relative to NIST1648 (urban particulate). All data reductions were based on consensus values for the standard reference materials as reported in Glascock (2006). 
In contrast, the data for elements with intermediate and long half-life isotopes (including As, Ba, $\mathrm{La}, \mathrm{Lu}, \mathrm{K}, \mathrm{Na}, \mathrm{Sm}, \mathrm{U}, \mathrm{Yb}, \mathrm{Ce}, \mathrm{Co}, \mathrm{Cr}, \mathrm{Cs}$, Eu, Fe, Hf, Nd, Rb, Sc, Sr, Ta, Tb, Th, Zn, Zr), result from an extended ( $7 \mathrm{hr}$ ) irradiation in the rotating rack, which experiences an average thermal neutron flux of $2 \times 10^{12} \mathrm{n} \mathrm{cm}^{-2} \mathrm{~s}^{-1}$. Following irradiation, two separate counts of gamma activity were recorded using a $32 \%$ relative efficiency HPGe detector. These include a 5000 -second count (live time) of each sample after a 1-week decay period, and a 10,000-second count (live time) after a period of 4 weeks decay. 


\subsection{SOIL-TO-PLANT TRANSFER FACTORS}

Soil-to-plant transfer factors for the nine crops, fruits, and nuts are estimated from the data prepared by this study. The transfer factors were evaluated from ratio of the arithmetic means of the concentrations of the available samples to the average concentrations of the three soil replicates. Uncertainties were propagated assuming that the measurements are uncorrelated (i.e., that there are no covariance terms).

In a few instances, the INAA analysis of the soil samples reported concentration values less than the reliable detection level. The INAA method was insufficiently sensitive for measuring $\mathrm{Br}$, $\mathrm{Cl}$, and $\mathrm{Ni}$ in soil samples. The $\mathrm{x}$-ray fluorescence measurements of soil provide a moresensitive measure for these elements, so these measurements were used for the estimation of transfer factors. A generic uncertainty of $10 \%$ was assumed for the $\mathrm{x}$-ray fluorescence measurements for this purpose as a conservative approximation (IAEA 2004).

For several elements, there were a large number of less-than or zero measurements in the vegetation samples. The elements for which this occurred include $\mathrm{Ti}, \mathrm{V}, \mathrm{Lu}, \mathrm{U}, \mathrm{Yb}, \mathrm{Nd}, \mathrm{Ta}, \mathrm{Tb}$, and $\mathrm{Zr}$. These are all trace elements with no known biological function. The less-than values were not used in the estimation of the transfer factors, and as a result there are several plant types for these elements for which no transfer factors are reported.

The transfer factors derived from the data discussed in Section 3 are presented in Tables 4.1 through 4.14. The transfer factors (soil-to-plant concentration ratios) are calculated by dividing the average measured concentration of the element in the plant portion by the average measured concentration in the soil. The uncertainties presented incorporate the variability in the plant and soil measurements and the measurement errors. The measurement uncertainties reflect counting uncertainty for net peak areas. The measurements of the plant concentration and the soil concentration are assumed to be uncorrelated (the covariance is assumed to be zero.) The reported uncertainty in the concentration ratio is then estimated as:

$$
\frac{\sigma_{C R}^{2}}{C R}=\frac{\sigma_{P}^{2}}{C_{P}}+\frac{\sigma_{S}^{2}}{C S}
$$

Where $\mathrm{CR}=$ concentration ratio

$\mathrm{C}_{\mathrm{P}}=$ concentration in plant

$\mathrm{C}_{\mathrm{S}}=$ concentration in soil

$\sigma_{C R}^{2}=$ variance of the concentration ratio

$\sigma_{P}^{2}=$ variance of the concentration in the plant

$\sigma_{S}^{2}=$ variance of the concentration in the soil.

Table 4.1 presents transfer factors for a forage (alfalfa) and a grain (oats) developed in this report. These are compared with similar transfer factors used in environmental modeling; the complete set of transfer factors used in the GENII Version 2.10 model (Napier et al. 2012) which are primarily based upon the International Atomic Energy Agency's (IAEA) Technical Report Series No. 364 (IAEA 1994). These are also compared with the newer values for temperate environments for all soil types compiled in IAEA Technical Reports Series No. 472 (IAEA 2009), 
supported with a larger compendium (IAEA 2010). It can be seen in Table 4.1 that the values found for this one location in Nevada are of the same general magnitude as the IAEA recommendations, although generally slightly lower as might be expected for a site-specific, rather than conservatively generic, analysis.

Tables 4.2 through 4.13 present the results for the specific fruit and nut trees evaluated herein almond, apple, apricot, carob, figs, grapes, nectarines, pecans, pistachios, and pomegranates. The results for pistachios are given for natural pistachios, grafted pistachios, and the two combined (there are minor differences - the uptake appears to be generally a little greater in the grafted variety). Table 4.14 presents a summary of the average of these fruits and nuts as generic transfer factors, which may be more appropriate for most general environmental analyses.

In the following tables, a double dash (--) indicates a combination for which there was insufficient data above detection limits to make an estimate. 
Table 4.1 Soil-to-Plant Transfer Values for Forage and Grain from this Study, Compared to Those in Current Use (unitless)

\begin{tabular}{|c|c|c|c|c|c|c|c|c|c|c|}
\hline \multirow[b]{2}{*}{ Element } & \multicolumn{4}{|c|}{ Current Study Values } & \multicolumn{3}{|c|}{ TRS-364 Values } & \multicolumn{3}{|c|}{ TRS-472 Values } \\
\hline & Forage & $\pm 1 \sigma$ & Grain & $\pm 1 \sigma$ & Forage & Grain & Fruit & Forage & Grain & Fruit \\
\hline Al & 0.002 & 0.001 & 0.004 & 0.002 & 0.00018 & 0.00018 & 0.00018 & & & \\
\hline $\mathrm{Br}$ & 0.002 & 0.001 & 0.004 & 0.002 & 1.5 & 1.5 & 1.5 & & & \\
\hline $\mathrm{Ca}$ & 0.495 & 0.152 & 0.108 & 0.031 & 3.5 & 0.35 & 0.35 & 8.7 & 20 & \\
\hline $\mathrm{Cl}$ & 0.514 & 0.206 & 0.302 & 0.107 & 70 & 70 & 70 & & 0.36 & \\
\hline Mg & 0.342 & 0.187 & 0.231 & 0.113 & 1 & 0.55 & 0.55 & & & \\
\hline Mn & 0.098 & 0.015 & 0.149 & 0.019 & 0.7 & 0.3 & 0.05 & 1.5 & 0.28 & 0.31 \\
\hline K & 1.073 & 0.298 & 0.278 & 0.071 & 1 & 0.55 & 0.55 & 0.74 & 0.74 & \\
\hline $\mathrm{Na}$ & 0.041 & 0.012 & 0.044 & 0.010 & 0.3 & 0.3 & 0.3 & 0.1 & 0.01 & 0.03 \\
\hline $\mathrm{Ti}$ & -- & -- & -- & -- & $5.40 \mathrm{E}-05$ & $5.40 \mathrm{E}-05$ & $5.40 \mathrm{E}-05$ & & & \\
\hline v & -- & -- & -- & -- & 0.0013 & 0.0013 & 0.0013 & & & \\
\hline As & 0.028 & 0.006 & -- & -- & 0.04 & 0.006 & 0.006 & & & \\
\hline La & 0.002 & 0.0001 & 0.002 & 0.0001 & 0.0052 & 0.004 & 0.004 & 0.02 & 0.00002 & 0.006 \\
\hline Lu & -- & -- & -- & -- & 0.02 & 0.02 & 0.02 & & & \\
\hline $\mathrm{Sm}$ & 0.002 & 0.001 & 0.002 & 0.0004 & 0.02 & 0.02 & 0.02 & & & \\
\hline $\mathrm{Na}$ & 0.042 & 0.004 & 0.047 & 0.004 & 0.3 & 0.3 & 0.3 & & & \\
\hline u & -- & -- & -- & -- & 0.0083 & 0.0013 & 0.004 & 0.015 & 0.0062 & 0.015 \\
\hline $\mathrm{Yb}$ & -- & -- & -- & -- & 0.02 & 0.02 & 0.02 & & & \\
\hline $\mathrm{Sb}$ & 0.074 & 0.028 & 0.043 & 0.014 & 0.00013 & 0.03 & 8.00E-05 & 0.007 & 0.0018 & 0.00013 \\
\hline $\mathrm{Ba}$ & 0.007 & 0.003 & 0.005 & 0.002 & 0.15 & 0.015 & 0.015 & 0.91 & 0.001 & 0.005 \\
\hline $\mathrm{Ce}$ & 0.002 & 0.0004 & 0.002 & 0.001 & 0.02 & 0.02 & 0.02 & 0.008 & 0.003 & \\
\hline Cs & 0.003 & 0.001 & 0.003 & 0.001 & 0.46 & 0.026 & 0.22 & 0.16 & 0.029 & 0.021 \\
\hline $\mathrm{Cr}$ & 0.010 & 0.004 & 0.025 & 0.006 & 0.0075 & 0.0045 & 0.0045 & 0.002 & 0.0002 & 0.001 \\
\hline Co & 0.027 & 0.003 & 0.022 & 0.002 & 0.23 & 0.0037 & 0.007 & 0.066 & 0.0085 & 0.14 \\
\hline Eu & 0.001 & -- & 0.002 & 0.001 & 0.02 & 0.02 & 0.02 & & & \\
\hline $\mathrm{Hf}$ & 0.001 & 0.0004 & 0.002 & 0.001 & 0.001 & 0.001 & 0.001 & & & \\
\hline $\mathrm{Fe}$ & 0.005 & 0.0003 & 0.004 & 0.0003 & 0.05 & 0.05 & 0.05 & 0.002 & 0.0002 & 0.001 \\
\hline $\mathrm{Nd}$ & -- & -- & -- & -- & 0.02 & 0.02 & 0.02 & & & \\
\hline $\mathrm{Ni}$ & 0.102 & 0.060 & 0.309 & 0.155 & 0.28 & 0.03 & 0.06 & 0.4 & 0.027 & \\
\hline $\mathbf{R b}$ & 0.124 & 0.023 & 0.052 & 0.009 & 0.9 & 0.9 & 0.9 & 0.61 & 0.9 & \\
\hline Sc & 0.002 & 0.0002 & 0.003 & 0.0002 & 0.006 & 0.001 & 0.001 & & & \\
\hline $\mathrm{Sr}$ & 0.277 & 0.131 & 0.049 & 0.022 & 3 & 0.21 & 0.2 & 3.7 & 0.11 & 0.36 \\
\hline $\mathrm{Ta}$ & 0.003 & 0.0004 & 0.002 & 0.001 & 0.025 & 0.025 & 0.025 & & & \\
\hline Tb & -- & -- & -- & -- & 0.02 & 0.02 & 0.02 & & & \\
\hline Th & 0.001 & 0.0002 & 0.002 & 0.0003 & 0.0018 & $3.40 \mathrm{E}-05$ & 0.00025 & 0.0026 & 0.0021 & 0.00078 \\
\hline $\mathrm{Zn}$ & 0.159 & 0.032 & 0.211 & 0.039 & 1.3 & 1.6 & 0.9 & 1 & 1.8 & 0.42 \\
\hline $\mathrm{Zr}$ & -- & -- & -- & -- & 0.001 & 0.001 & 0.001 & 0.01 & 0.001 & 0.004 \\
\hline
\end{tabular}


Table 4.2 Transfer Factors for Almonds (unitless)

\begin{tabular}{|c|c|c|c|c|c|c|}
\hline Element & Leaf & $\pm 1 \sigma$ & Stem & $\pm 1 \sigma$ & Nut & $\pm 1 \sigma$ \\
\hline Al & 0.007 & 0.003 & 0.001 & 0.0005 & 0.003 & 0.002 \\
\hline $\mathrm{Br}$ & -- & -- & -- & -- & -- & -- \\
\hline $\mathrm{Ca}$ & 1.588 & 0.309 & 0.734 & 0.156 & 0.105 & 0.033 \\
\hline $\mathrm{Cl}$ & 0.022 & 0.006 & 0.008 & 0.002 & 0.016 & 0.006 \\
\hline Mg & 0.680 & 0.238 & 0.084 & 0.029 & 0.142 & 0.079 \\
\hline Mn & 0.048 & 0.005 & 0.022 & 0.002 & 0.019 & 0.003 \\
\hline $\mathrm{K}$ & 0.712 & 0.125 & 0.146 & 0.026 & 0.793 & 0.218 \\
\hline $\mathrm{Na}$ & 0.118 & 0.023 & 0.022 & 0.005 & 0.027 & 0.007 \\
\hline $\mathrm{Ti}$ & 0.005 & 0.005 & -- & -- & 0.004 & 0.003 \\
\hline v & 0.013 & 0.006 & -- & -- & 0.011 & 0.008 \\
\hline As & 0.176 & 0.043 & 0.163 & 0.043 & 0.024 & 0.010 \\
\hline La & 0.008 & 0.0002 & 0.002 & 0.0001 & 0.004 & 0.0002 \\
\hline Lu & 0.008 & 0.002 & 0.002 & 0.001 & 0.003 & 0.002 \\
\hline Sm & 0.011 & 0.001 & 0.002 & 0.0002 & 0.005 & 0.001 \\
\hline $\mathrm{Na}$ & 0.128 & 0.009 & 0.022 & 0.002 & 0.024 & 0.003 \\
\hline U & 0.015 & 0.005 & -- & -- & 0.004 & -- \\
\hline $\mathrm{Yb}$ & 0.015 & 0.004 & -- & -- & 0.009 & 0.003 \\
\hline $\mathrm{Sb}$ & 0.035 & 0.008 & 0.176 & 0.038 & 0.098 & 0.033 \\
\hline $\mathrm{Ba}$ & 0.016 & 0.003 & 0.004 & 0.001 & 0.005 & 0.002 \\
\hline $\mathrm{Ce}$ & 0.009 & 0.0004 & 0.002 & 0.0001 & 0.004 & 0.0004 \\
\hline Cs & 0.013 & 0.001 & 0.003 & 0.0003 & 0.005 & 0.001 \\
\hline $\mathrm{Cr}$ & 0.055 & 0.008 & 0.012 & 0.002 & 0.028 & 0.007 \\
\hline Co & 0.023 & 0.002 & 0.006 & 0.0004 & 0.010 & 0.001 \\
\hline Eu & 0.009 & 0.001 & 0.002 & 0.0003 & 0.005 & 0.001 \\
\hline $\mathrm{Hf}$ & 0.009 & 0.001 & 0.002 & 0.0002 & 0.006 & 0.001 \\
\hline $\mathrm{Fe}$ & 0.018 & 0.001 & 0.004 & 0.0002 & 0.007 & 0.0005 \\
\hline $\mathrm{Nd}$ & 0.008 & 0.003 & -- & -- & -- & -- \\
\hline $\mathrm{Ni}$ & 0.288 & 0.070 & 0.271 & 0.111 & 0.295 & 0.165 \\
\hline $\mathbf{R b}$ & 0.077 & 0.009 & 0.016 & 0.002 & 0.122 & 0.022 \\
\hline Sc & 0.017 & 0.001 & 0.003 & 0.0001 & 0.006 & 0.001 \\
\hline $\mathrm{Sr}$ & 0.494 & 0.148 & 0.344 & 0.110 & 0.045 & 0.022 \\
\hline Ta & 0.010 & 0.002 & 0.002 & 0.0004 & 0.004 & 0.001 \\
\hline Tb & 0.008 & 0.003 & -- & -- & 0.004 & 0.002 \\
\hline Th & 0.010 & 0.0004 & 0.002 & 0.0001 & 0.005 & 0.0003 \\
\hline $\mathrm{Zn}$ & 0.099 & 0.013 & 0.051 & 0.007 & 0.118 & 0.024 \\
\hline $\mathrm{Zr}$ & 0.010 & 0.005 & -- & -- & 0.006 & 0.004 \\
\hline
\end{tabular}


Table 4.3 Transfer Factors for Apples (unitless)

\begin{tabular}{|c|c|c|c|c|c|c|}
\hline Element & Leaf & $\pm 1 \sigma$ & Stem & $\pm 1 \sigma$ & Fruit & $\pm 1 \sigma$ \\
\hline Al & 0.009 & 0.003 & 0.001 & 0.0004 & 0.001 & 0.0002 \\
\hline $\mathrm{Br}$ & 0.001 & 0.00002 & -- & -- & -- & -- \\
\hline $\mathrm{Ca}$ & 0.687 & 0.141 & 0.793 & 0.154 & 0.015 & 0.003 \\
\hline $\mathrm{Cl}$ & 0.039 & 0.011 & 0.005 & 0.002 & 0.003 & 0.001 \\
\hline Mg & 0.381 & 0.131 & 0.122 & 0.042 & 0.059 & 0.020 \\
\hline Mn & 0.101 & 0.009 & 0.032 & 0.003 & 0.006 & 0.001 \\
\hline $\mathbf{K}$ & 0.700 & 0.122 & 0.190 & 0.034 & 0.468 & 0.081 \\
\hline $\mathrm{Na}$ & 0.017 & 0.003 & 0.004 & 0.001 & 0.002 & 0.0004 \\
\hline $\mathrm{Ti}$ & -- & -- & -- & -- & -- & -- \\
\hline $\mathbf{v}$ & 0.023 & 0.012 & -- & -- & -- & -- \\
\hline As & 0.160 & 0.038 & 0.035 & 0.009 & 0.033 & 0.008 \\
\hline La & 0.009 & 0.0002 & 0.001 & 0.00004 & 0.001 & 0.00004 \\
\hline Lu & 0.007 & 0.002 & -- & -- & -- & -- \\
\hline Sm & 0.010 & 0.001 & 0.001 & 0.0001 & 0.001 & 0.0001 \\
\hline $\mathrm{Na}$ & 0.016 & 0.001 & 0.004 & 0.0003 & 0.002 & 0.0002 \\
\hline U & 0.012 & 0.006 & -- & -- & -- & -- \\
\hline $\mathrm{Yb}$ & 0.012 & 0.004 & -- & -- & -- & -- \\
\hline Sb & 0.047 & 0.010 & 0.045 & 0.010 & 0.090 & 0.021 \\
\hline $\mathrm{Ba}$ & 0.017 & 0.004 & 0.011 & 0.002 & -- & -- \\
\hline $\mathrm{Ce}$ & 0.010 & 0.0004 & 0.001 & 0.0002 & 0.001 & 0.0002 \\
\hline Cs & 0.013 & 0.001 & 0.002 & 0.0003 & 0.002 & 0.0003 \\
\hline $\mathrm{Cr}$ & 0.096 & 0.014 & 0.010 & 0.002 & 0.011 & 0.002 \\
\hline Co & 0.028 & 0.002 & 0.007 & 0.0004 & 0.003 & 0.0003 \\
\hline Eu & 0.011 & 0.001 & 0.001 & 0.0003 & 0.002 & 0.0003 \\
\hline $\mathrm{Hf}$ & 0.010 & 0.001 & 0.001 & 0.0002 & 0.001 & 0.0001 \\
\hline $\mathrm{Fe}$ & 0.019 & 0.001 & 0.003 & 0.0001 & 0.001 & 0.0001 \\
\hline Nd & 0.017 & 0.005 & -- & -- & -- & -- \\
\hline $\mathrm{Ni}$ & -- & -- & 0.083 & 0.033 & 0.126 & 0.054 \\
\hline $\mathbf{R b}$ & 0.136 & 0.016 & 0.046 & 0.005 & 0.139 & 0.017 \\
\hline Sc & 0.018 & 0.001 & 0.002 & 0.0001 & 0.001 & 0.0001 \\
\hline $\mathrm{Sr}$ & 0.232 & 0.075 & 0.286 & 0.089 & 0.004 & 0.002 \\
\hline Ta & 0.010 & 0.002 & 0.001 & 0.0003 & -- & -- \\
\hline Tb & 0.009 & 0.003 & -- & -- & -- & -- \\
\hline Th & 0.009 & 0.0003 & 0.001 & 0.0001 & 0.0008 & 0.0001 \\
\hline $\mathrm{Zn}$ & 0.171 & 0.022 & 0.225 & 0.033 & 0.022 & 0.003 \\
\hline $\mathrm{Zr}$ & 0.008 & 0.005 & -- & -- & -- & -- \\
\hline
\end{tabular}


Table 4.4 Transfer Factors for Apricots (unitless)

\begin{tabular}{|c|c|c|c|c|c|c|}
\hline Element & Leaf & $\pm 1 \sigma$ & Stem & $\pm 1 \sigma$ & Fruit & $\pm 1 \sigma$ \\
\hline Al & 0.001 & 0.0002 & 0.003 & 0.001 & 0.001 & 0.001 \\
\hline $\mathrm{Br}$ & -- & -- & -- & -- & -- & -- \\
\hline $\mathrm{Ca}$ & 0.617 & 0.084 & 0.662 & 0.135 & 0.323 & 0.009 \\
\hline $\mathrm{Cl}$ & 0.006 & 0.001 & 0.017 & 0.005 & 0.006 & 0.002 \\
\hline $\mathbf{M g}$ & 0.144 & 0.035 & 0.258 & 0.103 & 0.109 & 0.030 \\
\hline Mn & 0.040 & 0.003 & 0.079 & 0.009 & 0.024 & 0.001 \\
\hline $\mathrm{K}$ & 0.163 & 0.020 & 0.832 & 0.182 & 0.502 & 0.148 \\
\hline $\mathrm{Na}$ & 0.003 & 0.0003 & 0.005 & 0.001 & 0.003 & 0.001 \\
\hline $\mathrm{Ti}$ & -- & -- & -- & -- & -- & -- \\
\hline $\mathbf{v}$ & -- & -- & 0.019 & 0.008 & -- & -- \\
\hline As & 0.050 & 0.009 & 0.060 & 0.016 & 0.035 & 0.006 \\
\hline La & 0.001 & 0.00005 & 0.003 & 0.0001 & 0.001 & 0.0001 \\
\hline Lu & -- & -- & 0.004 & 0.001 & -- & -- \\
\hline Sm & 0.001 & 0.0001 & 0.004 & 0.0003 & 0.002 & 0.0004 \\
\hline $\mathrm{Na}$ & 0.003 & 0.0002 & 0.005 & 0.0004 & 0.003 & 0.0004 \\
\hline U & -- & -- & 0.005 & 0.000 & -- & -- \\
\hline $\mathrm{Yb}$ & -- & -- & 0.012 & 0.003 & -- & -- \\
\hline $\mathrm{Sb}$ & 0.026 & 0.004 & 0.075 & 0.017 & 0.032 & 0.009 \\
\hline $\mathrm{Ba}$ & 0.005 & 0.001 & 0.007 & 0.002 & 0.005 & 0.001 \\
\hline $\mathrm{Ce}$ & 0.001 & 0.0002 & 0.004 & 0.0003 & 0.001 & 0.0004 \\
\hline Cs & 0.002 & 0.0002 & 0.006 & 0.001 & 0.002 & 0.001 \\
\hline $\mathrm{Cr}$ & 0.009 & 0.001 & 0.026 & 0.005 & 0.009 & 0.003 \\
\hline Co & 0.005 & 0.0003 & 0.010 & 0.001 & 0.006 & 0.001 \\
\hline Eu & 0.002 & 0.0002 & 0.004 & 0.001 & 0.002 & 0.001 \\
\hline $\mathrm{Hf}$ & 0.001 & 0.0002 & 0.003 & 0.0004 & 0.001 & 0.001 \\
\hline $\mathrm{Fe}$ & 0.003 & 0.0001 & 0.008 & 0.0004 & 0.003 & 0.0003 \\
\hline $\mathrm{Nd}$ & -- & -- & -- & -- & -- & -- \\
\hline $\mathrm{Ni}$ & 0.063 & 0.019 & -- & -- & 0.112 & 0.061 \\
\hline $\mathbf{R b}$ & 0.044 & 0.004 & 0.140 & 0.019 & 0.144 & 0.036 \\
\hline Sc & 0.002 & 0.0001 & 0.007 & 0.0004 & 0.002 & 0.0003 \\
\hline $\mathrm{Sr}$ & 0.249 & 0.053 & 0.182 & 0.056 & 0.133 & 0.006 \\
\hline Ta & -- & -- & 0.007 & 0.001 & -- & -- \\
\hline Tb & -- & -- & -- & -- & -- & -- \\
\hline Th & 0.001 & 0.0001 & 0.003 & 0.0002 & 0.001 & 0.0002 \\
\hline$Z n$ & 0.189 & 0.017 & 0.128 & 0.017 & 0.133 & 0.015 \\
\hline $\mathrm{Zr}$ & -- & -- & -- & -- & -- & -- \\
\hline
\end{tabular}


Table 4.5 Transfer Factors for Carob (unitless)

\begin{tabular}{|c|c|c|c|c|c|c|}
\hline Element & Leaf & $\pm 1 \sigma$ & Stem & $\pm 1 \sigma$ & Fruit & $\pm 1 \sigma$ \\
\hline Al & 0.004 & 0.001 & 0.002 & 0.001 & 0.001 & 0.001 \\
\hline $\mathrm{Br}$ & 0.002 & 0.001 & -- & -- & -- & -- \\
\hline $\mathrm{Ca}$ & 0.668 & 0.132 & 0.409 & 0.082 & 0.225 & 0.063 \\
\hline $\mathrm{Cl}$ & 0.106 & 0.027 & 0.025 & 0.006 & 0.057 & 0.020 \\
\hline Mg & 0.254 & 0.088 & 0.075 & 0.027 & 0.139 & 0.068 \\
\hline Mn & 0.092 & 0.009 & 0.014 & 0.001 & 0.031 & 0.004 \\
\hline K & 0.409 & 0.071 & 0.134 & 0.025 & 0.559 & 0.137 \\
\hline $\mathrm{Na}$ & 0.007 & 0.001 & 0.004 & 0.001 & 0.001 & 0.0002 \\
\hline $\mathrm{Ti}$ & -- & -- & -- & -- & -- & -- \\
\hline $\mathbf{v}$ & -- & -- & -- & -- & -- & -- \\
\hline As & 0.036 & 0.011 & 0.016 & 0.004 & -- & -- \\
\hline La & 0.003 & 0.0001 & 0.002 & 0.0001 & 0.001 & 0.0001 \\
\hline Lu & 0.003 & 0.001 & 0.002 & 0.001 & 0.001 & 0.001 \\
\hline Sm & 0.005 & 0.0003 & 0.003 & 0.0002 & 0.001 & 0.0002 \\
\hline $\mathrm{Na}$ & 0.007 & 0.001 & 0.004 & 0.0003 & 0.001 & 0.0002 \\
\hline U & 0.002 & -- & -- & -- & -- & -- \\
\hline $\mathrm{Yb}$ & 0.005 & 0.002 & -- & -- & -- & -- \\
\hline $\mathrm{Sb}$ & 0.029 & 0.007 & 0.150 & 0.032 & 0.022 & 0.007 \\
\hline $\mathrm{Ba}$ & 0.009 & 0.002 & 0.005 & 0.001 & 0.003 & 0.001 \\
\hline $\mathrm{Ce}$ & 0.004 & 0.0003 & 0.002 & 0.0002 & 0.001 & 0.0003 \\
\hline Cs & 0.007 & 0.001 & 0.003 & 0.0004 & 0.002 & 0.001 \\
\hline $\mathrm{Cr}$ & 0.044 & 0.006 & 0.014 & 0.002 & 0.020 & 0.005 \\
\hline Co & 0.014 & 0.001 & 0.007 & 0.001 & 0.007 & 0.001 \\
\hline Eu & 0.005 & 0.0005 & 0.004 & 0.0004 & 0.002 & 0.001 \\
\hline $\mathrm{Hf}$ & 0.004 & 0.0004 & 0.002 & 0.0003 & 0.001 & 0.0003 \\
\hline $\mathrm{Fe}$ & 0.010 & 0.0004 & 0.004 & 0.0002 & 0.003 & 0.0002 \\
\hline $\mathbf{N d}$ & -- & -- & -- & -- & -- & -- \\
\hline $\mathrm{Ni}$ & 0.141 & 0.038 & 0.253 & 0.113 & 0.242 & 0.129 \\
\hline $\mathbf{R b}$ & 0.093 & 0.011 & 0.026 & 0.003 & 0.135 & 0.023 \\
\hline Sc & 0.008 & 0.0004 & 0.004 & 0.0002 & 0.002 & 0.0002 \\
\hline $\mathrm{Sr}$ & 0.173 & 0.055 & 0.173 & 0.057 & 0.073 & 0.032 \\
\hline $\mathrm{Ta}$ & 0.004 & 0.001 & 0.003 & 0.0005 & 0.001 & 0.0004 \\
\hline Tb & 0.004 & 0.002 & -- & -- & -- & -- \\
\hline Th & 0.004 & 0.0002 & 0.002 & 0.0001 & 0.001 & 0.0002 \\
\hline $\mathrm{Zn}$ & 0.168 & 0.022 & 0.104 & 0.014 & 0.222 & 0.041 \\
\hline $\mathrm{Zr}$ & -- & -- & -- & -- & -- & -- \\
\hline
\end{tabular}


Table 4.6 Transfer Factors for Figs (unitless)

\begin{tabular}{|c|c|c|c|c|c|c|}
\hline Element & Leaf & $\pm 1 \sigma$ & Stem & $\pm 1 \sigma$ & Fruit & $\pm 1 \sigma$ \\
\hline Al & 0.017 & 0.005 & 0.002 & 0.001 & 0.001 & 0.001 \\
\hline $\mathrm{Br}$ & 0.001 & 0.0004 & 0.001 & 0.0003 & 0.001 & 0.0005 \\
\hline $\mathrm{Ca}$ & 0.908 & 0.174 & 0.631 & 0.121 & 0.317 & 0.101 \\
\hline $\mathrm{Cl}$ & 0.174 & 0.044 & 0.150 & 0.042 & 0.171 & 0.068 \\
\hline Mg & 0.534 & 0.183 & 0.255 & 0.092 & 0.248 & 0.140 \\
\hline Mn & 0.098 & 0.009 & 0.044 & 0.004 & 0.026 & 0.004 \\
\hline $\mathrm{K}$ & 0.691 & 0.120 & 0.405 & 0.073 & 0.520 & 0.144 \\
\hline $\mathrm{Na}$ & 0.045 & 0.007 & 0.013 & 0.002 & 0.013 & 0.003 \\
\hline $\mathrm{Ti}$ & -- & -- & -- & -- & -- & -- \\
\hline $\mathbf{v}$ & 0.030 & 0.015 & -- & -- & -- & -- \\
\hline As & 0.050 & 0.010 & 0.010 & 0.003 & -- & -- \\
\hline La & 0.021 & 0.0005 & 0.002 & 0.00005 & 0.001 & 0.0001 \\
\hline Lu & 0.025 & 0.004 & -- & -- & -- & -- \\
\hline Sm & 0.024 & 0.001 & 0.002 & 0.0001 & 0.001 & 0.0002 \\
\hline $\mathrm{Na}$ & 0.060 & 0.004 & 0.013 & 0.001 & 0.014 & 0.001 \\
\hline U & 0.031 & 0.013 & 0.001 & -- & -- & -- \\
\hline $\mathrm{Yb}$ & 0.034 & 0.010 & 0.002 & 0.001 & -- & -- \\
\hline $\mathrm{Sb}$ & 0.066 & 0.015 & 0.043 & 0.010 & 0.119 & 0.042 \\
\hline $\mathrm{Ba}$ & 0.027 & 0.006 & 0.006 & 0.001 & 0.003 & 0.002 \\
\hline $\mathrm{Ce}$ & 0.022 & 0.001 & 0.002 & 0.0002 & 0.001 & 0.0002 \\
\hline Cs & 0.023 & 0.002 & 0.002 & 0.0002 & 0.002 & 0.001 \\
\hline $\mathrm{Cr}$ & 0.079 & 0.011 & 0.010 & 0.002 & 0.010 & 0.003 \\
\hline Co & 0.044 & 0.003 & 0.008 & 0.001 & 0.007 & 0.001 \\
\hline Eu & 0.024 & 0.002 & 0.001 & 0.0002 & 0.001 & 0.0004 \\
\hline $\mathrm{Hf}$ & 0.025 & 0.002 & 0.002 & 0.0002 & 0.001 & 0.0003 \\
\hline $\mathrm{Fe}$ & 0.035 & 0.001 & 0.003 & 0.0001 & 0.003 & 0.0002 \\
\hline Nd & 0.021 & 0.008 & -- & -- & -- & -- \\
\hline $\mathrm{Ni}$ & 1.049 & 0.259 & 0.110 & 0.041 & 0.266 & 0.164 \\
\hline $\mathbf{R b}$ & 0.106 & 0.013 & 0.051 & 0.006 & 0.080 & 0.015 \\
\hline Sc & 0.032 & 0.002 & 0.002 & 0.0001 & 0.001 & 0.0001 \\
\hline $\mathrm{Sr}$ & 0.346 & 0.104 & 0.261 & 0.078 & 0.109 & 0.053 \\
\hline Ta & 0.022 & 0.003 & 0.001 & 0.0003 & 0.004 & 0.001 \\
\hline $\mathrm{Tb}$ & 0.024 & 0.006 & 0.001 & 0.001 & -- & -- \\
\hline Th & 0.021 & 0.001 & 0.001 & 0.0001 & 0.001 & 0.0002 \\
\hline $\mathrm{Zn}$ & 0.200 & 0.026 & 0.101 & 0.013 & 0.165 & 0.034 \\
\hline $\mathrm{Zr}$ & 0.020 & 0.014 & -- & -- & -- & -- \\
\hline
\end{tabular}


Table 4.7 Transfer Factors for Grapes (unitless)

\begin{tabular}{|c|c|c|c|c|c|c|}
\hline Element & Leaf & $\pm 1 \sigma$ & Stem & $\pm 1 \sigma$ & Fruit & $\pm 1 \sigma$ \\
\hline Al & 0.007 & 0.002 & 0.001 & 0.0004 & 0.001 & 0.0003 \\
\hline $\mathrm{Br}$ & 0.001 & 0.001 & 0.003 & 0.001 & 0.001 & 0.001 \\
\hline $\mathrm{Ca}$ & 1.045 & 0.200 & 0.352 & 0.083 & 0.241 & 0.061 \\
\hline $\mathrm{Cl}$ & 0.103 & 0.026 & 0.321 & 0.104 & 0.160 & 0.072 \\
\hline Mg & 0.398 & 0.138 & 0.206 & 0.092 & 0.175 & 0.076 \\
\hline Mn & 0.179 & 0.016 & 0.067 & 0.007 & 0.044 & 0.005 \\
\hline K & 0.265 & 0.047 & 0.541 & 0.122 & 0.679 & 0.144 \\
\hline $\mathrm{Na}$ & 0.026 & 0.004 & 0.217 & 0.045 & 0.093 & 0.028 \\
\hline $\mathrm{Ti}$ & -- & -- & -- & -- & -- & -- \\
\hline $\mathbf{v}$ & -- & -- & -- & -- & -- & -- \\
\hline As & 0.164 & 0.040 & 0.088 & 0.029 & 0.064 & 0.023 \\
\hline La & 0.006 & 0.0001 & 0.001 & 0.00005 & 0.001 & 0.0001 \\
\hline Lu & -- & -- & -- & -- & -- & -- \\
\hline Sm & 0.007 & 0.0004 & 0.001 & 0.0001 & 0.001 & 0.0002 \\
\hline $\mathrm{Na}$ & 0.028 & 0.002 & 0.242 & 0.018 & 0.101 & 0.011 \\
\hline U & -- & -- & -- & -- & -- & -- \\
\hline $\mathrm{Yb}$ & -- & -- & -- & -- & -- & -- \\
\hline $\mathrm{Sb}$ & 0.072 & 0.015 & 0.260 & 0.101 & 0.110 & 0.037 \\
\hline $\mathrm{Ba}$ & 0.012 & 0.003 & 0.004 & 0.001 & 0.004 & 0.002 \\
\hline $\mathrm{Ce}$ & 0.006 & 0.0004 & 0.001 & 0.0002 & 0.001 & 0.0002 \\
\hline Cs & 0.009 & 0.001 & 0.002 & 0.001 & 0.002 & 0.0004 \\
\hline $\mathrm{Cr}$ & 0.025 & 0.004 & 0.017 & 0.004 & 0.012 & 0.003 \\
\hline Co & 0.023 & 0.001 & 0.016 & 0.001 & 0.007 & 0.001 \\
\hline Eu & 0.006 & 0.001 & 0.002 & 0.0002 & - & -- \\
\hline $\mathrm{Hf}$ & 0.005 & 0.001 & 0.001 & 0.0002 & 0.001 & 0.0003 \\
\hline $\mathrm{Fe}$ & 0.014 & 0.001 & 0.002 & 0.0002 & 0.003 & 0.0002 \\
\hline Nd & -- & -- & -- & -- & -- & -- \\
\hline $\mathrm{Ni}$ & -- & -- & 0.222 & 0.089 & 0.174 & 0.068 \\
\hline $\mathbf{R b}$ & 0.047 & 0.006 & 0.151 & 0.024 & 0.154 & 0.022 \\
\hline Sc & 0.012 & 0.001 & 0.001 & 0.0001 & 0.001 & 0.0001 \\
\hline $\mathrm{Sr}$ & 0.373 & 0.111 & 0.178 & 0.065 & 0.111 & 0.047 \\
\hline $\mathrm{Ta}$ & 0.006 & 0.001 & 0.002 & 0.0003 & -- & -- \\
\hline Tb & 0.005 & 0.001 & -- & -- & -- & -- \\
\hline Th & 0.006 & 0.0003 & 0.001 & 0.0001 & 0.001 & 0.0002 \\
\hline $\mathrm{Zn}$ & 0.198 & 0.025 & 0.314 & 0.050 & 0.144 & 0.026 \\
\hline $\mathrm{Zr}$ & -- & -- & -- & -- & -- & -- \\
\hline
\end{tabular}


Table 4.8 Transfer Factors for Nectarines (unitless)

\begin{tabular}{|c|c|c|c|c|c|c|}
\hline Element & Leaf & $\pm 1 \sigma$ & Stem & $\pm 1 \sigma$ & Fruit & $\pm 1 \sigma$ \\
\hline Al & 0.006 & 0.002 & 0.001 & 0.0003 & 0.001 & 0.0002 \\
\hline $\mathrm{Br}$ & 0.001 & 0.0002 & -- & -- & -- & -- \\
\hline $\mathrm{Ca}$ & 0.554 & 0.107 & 0.754 & 0.155 & 0.049 & 0.007 \\
\hline $\mathrm{Cl}$ & 0.057 & 0.015 & 0.007 & 0.002 & 0.006 & 0.001 \\
\hline Mg & 0.378 & 0.131 & 0.124 & 0.043 & 0.110 & 0.027 \\
\hline Mn & 0.132 & 0.012 & 0.058 & 0.006 & 0.020 & 0.001 \\
\hline K & 1.239 & 0.214 & 0.148 & 0.028 & 0.653 & 0.080 \\
\hline $\mathrm{Na}$ & 0.006 & 0.001 & 0.002 & 0.0004 & 0.001 & 0.0002 \\
\hline $\mathrm{Ti}$ & -- & -- & -- & -- & -- & -- \\
\hline v & -- & -- & -- & -- & -- & -- \\
\hline As & 0.062 & 0.015 & 0.034 & 0.009 & 0.005 & 0.001 \\
\hline La & 0.006 & 0.0001 & 0.001 & 0.00004 & 0.002 & 0.00003 \\
\hline Lu & 0.005 & 0.002 & 0.002 & 0.0004 & -- & -- \\
\hline Sm & 0.007 & 0.0005 & 0.002 & 0.0001 & 0.001 & 0.0001 \\
\hline $\mathrm{Na}$ & 0.006 & 0.0003 & 0.002 & 0.0001 & 0.001 & 0.00005 \\
\hline U & 0.011 & 0.005 & -- & -- & -- & -- \\
\hline $\mathrm{Yb}$ & 0.012 & 0.004 & -- & -- & -- & -- \\
\hline Sb & 0.051 & 0.011 & 0.138 & 0.029 & 0.167 & 0.025 \\
\hline $\mathrm{Ba}$ & 0.011 & 0.003 & 0.004 & 0.001 & -- & -- \\
\hline $\mathrm{Ce}$ & 0.007 & 0.0003 & 0.001 & 0.0001 & 0.002 & 0.0002 \\
\hline Cs & 0.012 & 0.001 & 0.002 & 0.0002 & 0.002 & 0.0003 \\
\hline $\mathrm{Cr}$ & 0.063 & 0.009 & 0.011 & 0.002 & 0.008 & 0.001 \\
\hline Co & 0.020 & 0.001 & 0.005 & 0.0004 & 0.005 & 0.0003 \\
\hline $\mathrm{Eu}$ & 0.007 & 0.001 & 0.001 & 0.0003 & 0.001 & 0.0002 \\
\hline $\mathrm{Hf}$ & 0.005 & 0.001 & 0.001 & 0.0002 & 0.001 & 0.0002 \\
\hline $\mathrm{Fe}$ & 0.015 & 0.001 & 0.003 & 0.0001 & 0.003 & 0.0001 \\
\hline Nd & -- & -- & -- & -- & -- & -- \\
\hline $\mathrm{Ni}$ & 0.141 & 0.042 & 0.260 & 0.112 & 0.375 & 0.095 \\
\hline $\mathbf{R b}$ & 0.293 & 0.034 & 0.054 & 0.007 & 0.302 & 0.025 \\
\hline Sc & 0.014 & 0.001 & 0.002 & 0.0001 & 0.002 & 0.0001 \\
\hline $\mathrm{Sr}$ & 0.136 & 0.041 & 0.251 & 0.080 & 0.013 & 0.003 \\
\hline $\mathrm{Ta}$ & 0.007 & 0.001 & 0.003 & 0.0004 & -- & -- \\
\hline Tb & 0.007 & 0.002 & -- & -- & -- & -- \\
\hline Th & 0.007 & 0.0003 & 0.001 & 0.0001 & 0.001 & 0.0001 \\
\hline $\mathrm{Zn}$ & 0.134 & 0.017 & 0.155 & 0.023 & 0.123 & 0.011 \\
\hline $\mathrm{Zr}$ & -- & -- & -- & -- & -- & -- \\
\hline
\end{tabular}


Table 4.9 Transfer Factors for Pecans (unitless)

\begin{tabular}{|c|c|c|c|c|c|c|}
\hline Element & Leaf & $\pm 1 \sigma$ & Stem & $\pm 1 \sigma$ & Fruit & $\pm 1 \sigma$ \\
\hline $\mathrm{Al}$ & 0.003 & 0.001 & 0.001 & 0.0002 & -- & -- \\
\hline $\mathrm{Br}$ & 0.003 & 0.001 & -- & -- & -- & -- \\
\hline $\mathrm{Ca}$ & 0.734 & 0.099 & 0.504 & 0.068 & 0.042 & 0.006 \\
\hline $\mathrm{Cl}$ & 0.553 & 0.098 & 0.083 & 0.015 & 0.066 & 0.012 \\
\hline Mg & 0.358 & 0.087 & 0.087 & 0.021 & 0.060 & 0.015 \\
\hline Mn & 0.088 & 0.006 & 0.024 & 0.002 & 0.009 & 0.001 \\
\hline $\mathrm{K}$ & 0.724 & 0.089 & 0.193 & 0.024 & 0.397 & 0.049 \\
\hline $\mathrm{Na}$ & 0.004 & 0.001 & 0.003 & 0.0004 & 0.0005 & 0.0001 \\
\hline $\mathrm{Ti}$ & -- & -- & -- & -- & -- & -- \\
\hline $\mathbf{V}$ & -- & -- & -- & -- & -- & - \\
\hline As & 0.020 & 0.004 & 0.077 & 0.013 & -- & --0 \\
\hline La & 0.003 & 0.0001 & 0.001 & 0.00000 & 0.0002 & 0.00001 \\
\hline Lu & -- & -- & -- & -- & -- & -- \\
\hline $\mathrm{Sm}$ & 0.004 & 0.0002 & 0.002 & 0.0001 & -- & -- \\
\hline $\mathrm{Na}$ & 0.005 & 0.0002 & 0.004 & 0.00010 & 0.001 & 0.00005 \\
\hline U & -- & -- & -- & -- & -- & -- \\
\hline $\mathrm{Yb}$ & -- & -- & -- & -- & -- & -- \\
\hline Sb & 0.023 & 0.004 & 0.935 & 0.137 & 0.060 & 0.009 \\
\hline $\mathrm{Ba}$ & 0.005 & 0.001 & 0.003 & 0.001 & -- & -- \\
\hline $\mathrm{Ce}$ & 0.004 & 0.0002 & 0.002 & 0.0001 & -- & -- \\
\hline Cs & 0.006 & 0.0004 & 0.002 & 0.0002 & -- & -- \\
\hline $\mathrm{Cr}$ & 0.026 & 0.003 & 0.016 & 0.002 & 0.003 & 0.001 \\
\hline Co & 0.011 & 0.0005 & 0.005 & 0.0003 & 0.002 & 0.0002 \\
\hline Eu & 0.004 & 0.0003 & -- & -- & -- & -- \\
\hline $\mathrm{Hf}$ & 0.003 & 0.0002 & 0.001 & 0.0001 & -- & -- \\
\hline $\mathrm{Fe}$ & 0.009 & 0.0003 & 0.003 & 0.0001 & 0.001 & 0.0001 \\
\hline Nd & -- & -- & -- & -- & -- & -- \\
\hline $\mathrm{Ni}$ & -- & -- & 0.191 & 0.049 & 0.275 & 0.069 \\
\hline $\mathbf{R b}$ & 0.088 & 0.007 & 0.031 & 0.003 & 0.085 & 0.007 \\
\hline Sc & 0.008 & 0.0003 & 0.003 & 0.0001 & 0.0002 & 0.0000 \\
\hline $\mathrm{Sr}$ & 0.208 & 0.044 & 0.208 & 0.044 & 0.015 & 0.003 \\
\hline $\mathrm{Ta}$ & 0.004 & 0.0004 & -- & -- & -- & -- \\
\hline Tb & 0.004 & 0.001 & -- & -- & -- & -- \\
\hline Th & 0.004 & 0.0001 & 0.001 & 0.0001 & -- & -- \\
\hline $\mathrm{Zn}$ & 0.193 & 0.017 & 0.121 & 0.011 & 0.211 & 0.019 \\
\hline $\mathrm{Zr}$ & 0.003 & 0.001 & 0.002 & 0.001 & 0.002 & 0.001 \\
\hline
\end{tabular}


Table 4.10 Transfer Factors for Grafted Pistachios (unitless)

\begin{tabular}{|c|c|c|c|c|c|c|}
\hline Element & Leaf & $\pm 1 \sigma$ & Stem & $\pm 1 \sigma$ & Nut & $\pm 1 \sigma$ \\
\hline $\mathrm{Al}$ & 0.005 & 0.002 & 0.005 & 0.002 & 0.0004 & 0.0002 \\
\hline $\mathrm{Br}$ & 0.003 & 0.001 & -- & -- & -- & -- \\
\hline $\mathrm{Ca}$ & 0.893 & 0.244 & 0.586 & 0.164 & 0.034 & 0.010 \\
\hline $\mathrm{Cl}$ & 0.364 & 0.133 & 0.015 & 0.006 & 0.035 & 0.013 \\
\hline Mg & 0.640 & 0.314 & 0.116 & 0.057 & 0.070 & 0.034 \\
\hline$M n$ & 0.117 & 0.015 & 0.067 & 0.009 & 0.009 & 0.001 \\
\hline $\mathbf{K}$ & 0.608 & 0.150 & 0.207 & 0.053 & 0.481 & 0.118 \\
\hline $\mathrm{Na}$ & 0.008 & 0.002 & 0.007 & 0.002 & 0.001 & 0.0003 \\
\hline $\mathrm{Ti}$ & -- & -- & -- & -- & -- & -- \\
\hline V & -- & -- & 0.013 & 0.008 & -- & -- \\
\hline As & 0.142 & 0.050 & 0.021 & 0.008 & 0.020 & 0.008 \\
\hline La & 0.006 & 0.0002 & 0.006 & 0.0003 & 0.0004 & 0.0003 \\
\hline Lu & 0.005 & 0.002 & 0.008 & 0.002 & -- & -- \\
\hline Sm & 0.007 & 0.001 & 0.007 & 0.001 & 0.0005 & 0.0002 \\
\hline $\mathrm{Na}$ & 0.008 & 0.001 & 0.007 & 0.001 & 0.001 & 0.0001 \\
\hline $\mathbf{U}$ & 0.010 & 0.004 & 0.007 & 0.005 & -- & -- \\
\hline $\mathrm{Yb}$ & 0.013 & 0.003 & 0.012 & 0.004 & -- & -- \\
\hline Sb & 0.061 & 0.021 & 0.179 & 0.066 & 0.209 & 0.064 \\
\hline $\mathrm{Ba}$ & 0.016 & 0.005 & 0.011 & 0.004 & -- & -- \\
\hline $\mathrm{Ce}$ & 0.006 & 0.001 & 0.007 & 0.0005 & 0.001 & 0.0002 \\
\hline Cs & 0.010 & 0.001 & 0.008 & 0.001 & 0.002 & 0.0004 \\
\hline $\mathrm{Cr}$ & 0.056 & 0.011 & 0.034 & 0.008 & 0.009 & 0.003 \\
\hline Co & 0.015 & 0.001 & 0.014 & 0.002 & 0.003 & 0.001 \\
\hline $\mathrm{Eu}$ & 0.006 & 0.001 & 0.006 & 0.001 & 0.002 & 0.001 \\
\hline $\mathrm{Hf}$ & 0.005 & 0.001 & 0.006 & 0.001 & 0.0008 & 0.0002 \\
\hline $\mathrm{Fe}$ & 0.012 & 0.001 & 0.011 & 0.001 & 0.002 & 0.0002 \\
\hline $\mathrm{Nd}$ & -- & -- & 0.009 & 0.004 & -- & -- \\
\hline $\mathrm{Ni}$ & 0.052 & 0.025 & 0.040 & 0.021 & 0.489 & 0.258 \\
\hline $\mathbf{R b}$ & 0.075 & 0.013 & 0.030 & 0.005 & 0.094 & 0.016 \\
\hline Sc & 0.011 & 0.001 & 0.010 & 0.001 & 0.001 & 0.0001 \\
\hline $\mathrm{Sr}$ & 0.347 & 0.154 & 0.300 & 0.133 & 0.018 & 0.009 \\
\hline $\mathrm{Ta}$ & 0.006 & 0.002 & 0.005 & 0.002 & -- & -- \\
\hline Tb & 0.007 & 0.003 & 0.008 & 0.004 & -- & -- \\
\hline Th & 0.007 & 0.0004 & 0.006 & 0.0004 & 0.0004 & 0.0001 \\
\hline $\mathrm{Zn}$ & 0.148 & 0.028 & 0.115 & 0.022 & 0.140 & 0.027 \\
\hline $\mathrm{Zr}$ & -- & -- & 0.019 & 0.011 & -- & -- \\
\hline
\end{tabular}


Table 4.11 Transfer Factors for Natural Pistachios (unitless)

\begin{tabular}{|c|c|c|c|c|c|c|}
\hline Element & Leaf & $\pm 1 \sigma$ & Stem & $\pm 1 \sigma$ & Nut & $\pm 1 \sigma$ \\
\hline Al & 0.005 & 0.002 & 0.006 & 0.002 & 0.001 & 0.0004 \\
\hline $\mathrm{Br}$ & 0.002 & 0.001 & -- & -- & 0.001 & 0.0002 \\
\hline $\mathrm{Ca}$ & 0.573 & 0.139 & 0.788 & 0.186 & 0.086 & 0.021 \\
\hline $\mathrm{Cl}$ & 0.138 & 0.044 & 0.022 & 0.007 & 0.077 & 0.024 \\
\hline $\mathrm{Mg}$ & 0.476 & 0.206 & 0.175 & 0.074 & 0.121 & 0.052 \\
\hline $\mathrm{Mn}$ & 0.093 & 0.010 & 0.057 & 0.006 & 0.018 & 0.002 \\
\hline $\mathrm{K}$ & 0.344 & 0.074 & 0.252 & 0.055 & 0.559 & 0.119 \\
\hline $\mathrm{Na}$ & 0.007 & 0.001 & 0.005 & 0.001 & 0.002 & 0.0004 \\
\hline $\mathrm{Ti}$ & -- & -- & -- & -- & -- & -- \\
\hline $\mathbf{v}$ & 0.014 & 0.005 & 0.016 & 0.007 & -- & -- \\
\hline As & 0.087 & 0.029 & 0.026 & 0.009 & 0.028 & 0.010 \\
\hline La & 0.004 & 0.0001 & 0.007 & 0.0002 & 0.001 & 0.00005 \\
\hline Lu & 0.006 & 0.001 & 0.008 & 0.002 & -- & -- \\
\hline Sm & 0.006 & 0.0005 & 0.009 & 0.001 & 0.001 & 0.0002 \\
\hline $\mathrm{Na}$ & 0.005 & 0.0004 & 0.004 & 0.0004 & 0.001 & 0.0001 \\
\hline U & 0.006 & 0.004 & 0.006 & 0.004 & -- & -- \\
\hline $\mathrm{Yb}$ & 0.007 & 0.003 & 0.007 & 0.003 & -- & -- \\
\hline $\mathrm{Sb}$ & 0.047 & 0.013 & 0.062 & 0.018 & 0.054 & 0.016 \\
\hline $\mathrm{Ba}$ & 0.019 & 0.004 & 0.019 & 0.005 & -- & -- \\
\hline $\mathrm{Ce}$ & 0.005 & 0.0004 & 0.008 & 0.0004 & 0.001 & 0.0003 \\
\hline Cs & 0.008 & 0.001 & 0.009 & 0.001 & 0.002 & 0.0004 \\
\hline $\mathrm{Cr}$ & 0.023 & 0.005 & 0.023 & 0.005 & 0.006 & 0.002 \\
\hline Co & 0.015 & 0.001 & 0.017 & 0.001 & 0.004 & 0.0005 \\
\hline $\mathrm{Eu}$ & 0.008 & 0.001 & 0.008 & 0.001 & 0.002 & 0.0003 \\
\hline $\mathrm{Hf}$ & 0.004 & 0.001 & 0.005 & 0.001 & 0.001 & 0.0003 \\
\hline $\mathrm{Fe}$ & 0.010 & 0.001 & 0.011 & 0.001 & 0.003 & 0.0002 \\
\hline $\mathrm{Nd}$ & 0.011 & 0.004 & 0.005 & 0.003 & -- & -- \\
\hline $\mathrm{Ni}$ & 0.275 & 0.138 & 0.070 & 0.027 & 0.156 & 0.075 \\
\hline $\mathbf{R b}$ & 0.099 & 0.017 & 0.045 & 0.007 & 0.101 & 0.016 \\
\hline Sc & 0.010 & 0.001 & 0.010 & 0.001 & 0.002 & 0.0001 \\
\hline $\mathrm{Sr}$ & 0.156 & 0.071 & 0.362 & 0.136 & 0.027 & 0.012 \\
\hline $\mathrm{Ta}$ & 0.007 & 0.001 & 0.006 & 0.002 & -- & -- \\
\hline Tb & 0.006 & 0.002 & 0.008 & 0.003 & -- & -- \\
\hline Th & 0.005 & 0.0003 & 0.007 & 0.0003 & 0.001 & 0.0002 \\
\hline $\mathrm{Zn}$ & 0.114 & 0.018 & 0.049 & 0.009 & 0.089 & 0.016 \\
\hline $\mathrm{Zr}$ & 0.004 & 0.002 & -- & -- & -- & -- \\
\hline
\end{tabular}


Table 4.12 Transfer Factors for Pistachios (Natural + Grafted) (unitless)

\begin{tabular}{|c|c|c|c|c|c|c|}
\hline Element & Leaf & $\pm 1 \sigma$ & Stem & $\pm 1 \sigma$ & Nut & $\pm 1 \sigma$ \\
\hline Al & 0.005 & 0.003 & 0.005 & 0.003 & 0.001 & 0.0004 \\
\hline $\mathrm{Br}$ & 0.003 & 0.002 & -- & -- & -- & -- \\
\hline $\mathrm{Ca}$ & 0.733 & 0.281 & 0.687 & 0.248 & 0.060 & 0.023 \\
\hline $\mathrm{Cl}$ & 0.251 & 0.140 & 0.018 & 0.009 & 0.056 & 0.027 \\
\hline $\mathrm{Mg}$ & 0.558 & 0.376 & 0.145 & 0.093 & 0.095 & 0.062 \\
\hline Mn & 0.105 & 0.018 & 0.062 & 0.011 & 0.014 & 0.002 \\
\hline K & 0.476 & 0.168 & 0.229 & 0.076 & 0.520 & 0.167 \\
\hline $\mathrm{Na}$ & 0.007 & 0.002 & 0.006 & 0.002 & 0.001 & 0.0005 \\
\hline $\mathrm{Ti}$ & -- & -- & -- & -- & -- & -- \\
\hline v & 0.014 & 0.005 & 0.015 & 0.010 & -- & -- \\
\hline As & 0.115 & 0.058 & 0.023 & 0.012 & 0.024 & 0.013 \\
\hline La & 0.005 & 0.0003 & 0.007 & 0.0003 & 0.001 & 0.0001 \\
\hline Lu & 0.005 & 0.003 & 0.008 & 0.003 & -- & -- \\
\hline Sm & 0.006 & 0.001 & 0.008 & 0.001 & 0.001 & 0.0002 \\
\hline $\mathrm{Na}$ & 0.006 & 0.001 & 0.005 & 0.001 & 0.001 & 0.0001 \\
\hline U & 0.008 & 0.006 & 0.007 & 0.007 & -- & -- \\
\hline $\mathrm{Yb}$ & 0.010 & 0.004 & 0.009 & 0.005 & -- & -- \\
\hline $\mathrm{Sb}$ & 0.054 & 0.025 & 0.121 & 0.068 & 0.132 & 0.066 \\
\hline $\mathrm{Ba}$ & 0.018 & 0.007 & 0.015 & 0.006 & -- & -- \\
\hline $\mathrm{Ce}$ & 0.006 & 0.001 & 0.007 & 0.001 & 0.001 & 0.0003 \\
\hline Cs & 0.009 & 0.002 & 0.008 & 0.002 & 0.002 & 0.001 \\
\hline $\mathrm{Cr}$ & 0.039 & 0.012 & 0.028 & 0.009 & 0.007 & 0.004 \\
\hline Co & 0.015 & 0.002 & 0.016 & 0.002 & 0.004 & 0.001 \\
\hline Eu & 0.007 & 0.001 & 0.007 & 0.002 & 0.002 & 0.001 \\
\hline $\mathrm{Hf}$ & 0.005 & 0.001 & 0.006 & 0.001 & 0.001 & 0.0003 \\
\hline $\mathrm{Fe}$ & 0.011 & 0.001 & 0.011 & 0.001 & 0.003 & 0.0003 \\
\hline $\mathrm{Nd}$ & 0.011 & 0.004 & 0.007 & 0.005 & -- & -- \\
\hline $\mathrm{Ni}$ & 0.164 & 0.140 & 0.055 & 0.034 & 0.322 & 0.269 \\
\hline $\mathbf{R b}$ & 0.087 & 0.022 & 0.038 & 0.009 & 0.097 & 0.022 \\
\hline Sc & 0.010 & 0.001 & 0.010 & 0.001 & 0.001 & 0.0002 \\
\hline $\mathrm{Sr}$ & 0.251 & 0.169 & 0.331 & 0.191 & 0.023 & 0.015 \\
\hline $\mathrm{Ta}$ & 0.006 & 0.002 & 0.006 & 0.003 & -- & -- \\
\hline Tb & 0.007 & 0.004 & 0.008 & 0.005 & -- & -- \\
\hline Th & 0.006 & 0.001 & 0.007 & 0.001 & 0.001 & 0.0002 \\
\hline $\mathrm{Zn}$ & 0.131 & 0.033 & 0.082 & 0.024 & 0.114 & 0.031 \\
\hline $\mathrm{Zr}$ & 0.004 & 0.002 & 0.019 & 0.011 & -- & -- \\
\hline
\end{tabular}


Table 4.13 Transfer Factors for Pomegranates (unitless)

\begin{tabular}{|c|c|c|c|c|c|c|}
\hline Element & Leaf & $\pm 1 \sigma$ & Stem & $\pm 1 \sigma$ & Fruit & $\pm 1 \sigma$ \\
\hline Al & 0.003 & 0.001 & 0.002 & 0.0005 & -- & -- \\
\hline $\mathrm{Br}$ & 0.005 & 0.002 & 0.001 & 0.001 & 0.002 & 0.001 \\
\hline $\mathrm{Ca}$ & 0.830 & 0.197 & 0.566 & 0.132 & 0.090 & 0.022 \\
\hline $\mathrm{Cl}$ & 0.531 & 0.165 & 0.192 & 0.060 & 0.318 & 0.097 \\
\hline Mg & 0.253 & 0.107 & 0.088 & 0.038 & 0.093 & 0.040 \\
\hline $\mathrm{Mn}$ & 0.078 & 0.009 & 0.023 & 0.003 & 0.013 & 0.001 \\
\hline $\mathbf{K}$ & 0.367 & 0.080 & 0.236 & 0.051 & 0.521 & 0.110 \\
\hline $\mathrm{Na}$ & 0.004 & 0.001 & 0.006 & 0.001 & 0.004 & 0.001 \\
\hline $\mathrm{Ti}$ & -- & -- & -- & -- & -- & -- \\
\hline $\mathbf{v}$ & -- & -- & -- & -- & -- & -- \\
\hline As & 0.061 & 0.019 & 0.011 & 0.004 & -- & -- \\
\hline La & 0.004 & 0.0001 & 0.002 & 0.0001 & -- & -- \\
\hline Lu & 0.003 & -- & 0.001 & 0.001 & -- & -- \\
\hline Sm & 0.005 & 0.0004 & 0.003 & 0.0002 & -- & -- \\
\hline $\mathrm{Na}$ & 0.004 & 0.0003 & 0.006 & 0.0004 & 0.004 & 0.0004 \\
\hline U & -- & -- & 0.001 & -- & -- & -- \\
\hline $\mathrm{Yb}$ & -- & -- & 0.002 & 0.001 & -- & -- \\
\hline Sb & 0.039 & 0.011 & 0.173 & 0.049 & 0.133 & 0.036 \\
\hline $\mathrm{Ba}$ & 0.010 & 0.003 & 0.007 & 0.002 & -- & -- \\
\hline $\mathrm{Ce}$ & 0.004 & 0.0004 & 0.002 & 0.0003 & -- & -- \\
\hline Cs & 0.008 & 0.001 & 0.003 & 0.0005 & 0.001 & 0.0003 \\
\hline $\mathrm{Cr}$ & 0.031 & 0.006 & 0.021 & 0.004 & 0.009 & 0.003 \\
\hline Co & 0.014 & 0.001 & 0.010 & 0.001 & 0.004 & 0.001 \\
\hline $\mathrm{Eu}$ & 0.004 & 0.001 & 0.002 & 0.001 & -- & -- \\
\hline $\mathrm{Hf}$ & 0.003 & 0.0005 & 0.002 & 0.0003 & -- & -- \\
\hline $\mathrm{Fe}$ & 0.009 & 0.0005 & 0.004 & 0.0002 & 0.001 & 0.0001 \\
\hline $\mathrm{Nd}$ & -- & -- & -- & -- & -- & -- \\
\hline $\mathrm{Ni}$ & 0.067 & 0.020 & 0.062 & 0.032 & 0.587 & 0.272 \\
\hline $\mathbf{R b}$ & 0.037 & 0.006 & 0.024 & 0.004 & 0.059 & 0.009 \\
\hline Sc & 0.008 & 0.0005 & 0.004 & 0.0002 & 0.00009 & 0.00002 \\
\hline $\mathrm{Sr}$ & 0.340 & 0.129 & 0.291 & 0.110 & 0.034 & 0.013 \\
\hline $\mathrm{Ta}$ & 0.004 & 0.001 & 0.003 & 0.0004 & -- & -- \\
\hline Tb & 0.006 & 0.002 & 0.003 & 0.001 & -- & -- \\
\hline Th & 0.004 & 0.0002 & 0.002 & 0.0002 & -- & -- \\
\hline $\mathrm{Zn}$ & 0.123 & 0.020 & 0.142 & 0.023 & 0.151 & 0.024 \\
\hline $\mathrm{Zr}$ & -- & -- & -- & -- & -- & -- \\
\hline
\end{tabular}




\begin{tabular}{|c|c|c|c|c|c|c|c|c|c|c|c|c|c|c|c|c|c|c|c|c|c|c|c|c|c|c|c|}
\hline & $\frac{b}{+1}$ & $\begin{array}{l}\hat{\sigma} \\
\overline{8} \\
0\end{array}$ & $\mid \begin{array}{l}0 \\
0 \\
0 \\
0 \\
0\end{array}$ & $\begin{array}{l}\infty \\
0 \\
0 \\
0 \\
0\end{array}$ & $\begin{array}{l}\bar{\delta} \\
\text { ర్ } \\
0\end{array}$ & $\begin{array}{l}\frac{N}{0} \\
\stackrel{0}{\circ}\end{array}$ & 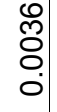 & 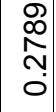 & $\begin{array}{l}8 \\
0 \\
8 \\
0 \\
0\end{array}$ & $\begin{array}{l}\dddot{0} \\
\text { o̊ } \\
0\end{array}$ & 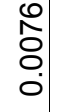 & $\begin{array}{l}2 \\
0 \\
0 \\
0 \\
0\end{array}$ & 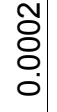 & $\begin{array}{l}0 \\
\stackrel{0}{8} \\
0 \\
0\end{array}$ & $\begin{array}{l}8 \\
\varnothing \\
8 \\
0 \\
0\end{array}$ & 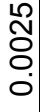 & 1 & 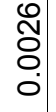 & 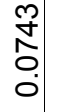 & $\begin{array}{l}\text { N̦} \\
\vdots \\
0\end{array}$ & $\begin{array}{l}20 \\
8 \\
8 \\
0\end{array}$ & $\begin{array}{l}\overline{8} \\
\dot{0}\end{array}$ & $\begin{array}{l}\hat{\hat{O}} \\
8 \\
0\end{array}$ & $\begin{array}{l}\frac{m}{8} \\
\stackrel{0}{0}\end{array}$ & $\begin{array}{l}5 \\
\overline{0} \\
0\end{array}$ & $\begin{array}{l}8 \\
8 \\
\vdots \\
\vdots\end{array}$ & $\begin{array}{l}\text { 오 } \\
8 \\
\circ \\
\circ\end{array}$ \\
\hline & $\frac{\mathbf{z}}{\mathbf{z}}$ & 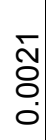 & $\begin{array}{l}1 \\
0 \\
0 \\
0 \\
0\end{array}$ & $\begin{array}{l}0 \\
0 \\
0 \\
0 \\
0 \\
0\end{array}$ & $\begin{array}{l}10 \\
0 \\
0 \\
0\end{array}$ & $\begin{array}{l}\text { D } \\
0 \\
0 \\
0 \\
0\end{array}$ & 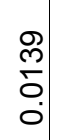 & $\left|\begin{array}{c}5 \\
0 \\
10 \\
0\end{array}\right|$ & $\begin{array}{l}2 \\
\stackrel{2}{ } \\
\delta \\
0 \\
0\end{array}$ & $\begin{array}{l}\tilde{ల} \\
\text { రి } \\
0 \\
0\end{array}$ & $\begin{array}{l}\check{\sigma} \\
\bar{\sigma} \\
\dot{0}\end{array}$ & 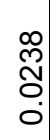 & $\begin{array}{l}0 \\
\stackrel{0}{0} \\
0 \\
0\end{array}$ & $\begin{array}{l}\text { ల్ } \\
\check{O} \\
0 \\
0\end{array}$ & 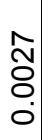 & $\begin{array}{l}\infty \\
0 \\
0 \\
0 \\
0 \\
0\end{array}$ & $\begin{array}{l}\mathfrak{Y} \\
\text { ठे } \\
0\end{array}$ & $\begin{array}{l}8 \\
8 \\
0 \\
0\end{array}$ & 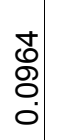 & \begin{tabular}{l}
$\stackrel{\circ}{\circ}$ \\
\hdashline \\
0
\end{tabular} & 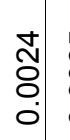 & $\begin{array}{l}\text { లొ } \\
\text { రి } \\
0 \\
0\end{array}$ & 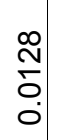 & $\begin{array}{l}\text { Tิ } \\
0 \\
0 \\
0\end{array}$ & $\begin{array}{l}\dddot{m} \\
\grave{O} \\
\vdots \\
0\end{array}$ & $\begin{array}{l}\dddot{m} \\
\stackrel{0}{0} \\
0 \\
\vdots\end{array}$ & 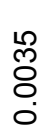 \\
\hline $\begin{array}{l}3 \\
\mathbf{z} \\
.0\end{array}$ & $\frac{b}{+1}$ & $\begin{array}{l}\bar{\varnothing} \\
\text { ठ̊ } \\
0\end{array}$ & $\begin{array}{l}\mathcal{N} \\
\text { రิ } \\
0 \\
0 \\
0\end{array}$ & $\begin{array}{l}\hat{0} \\
\text { م. } \\
0 \\
0\end{array}$ & 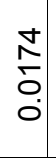 & $\frac{\overline{8}}{\dot{0}}$ & $\begin{array}{l}\frac{N}{\sigma} \\
0 \\
0\end{array}$ & 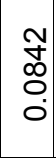 & 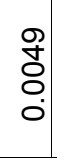 & 1 & $\begin{array}{l}m \\
0 \\
0 \\
0 \\
0\end{array}$ & $\begin{array}{l}\mathbf{U} \\
\vdots \\
0 \\
\vdots \\
0\end{array}$ & $\begin{array}{l}m \\
\text { రి } \\
0 \\
0\end{array}$ & 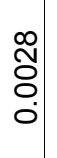 & $\begin{array}{l}\text { : } \\
8 \\
8 \\
\circ \\
\circ\end{array}$ & $\begin{array}{l}\infty \\
\check{\delta} \\
0 \\
0\end{array}$ & $\begin{array}{l}10 \\
8 \\
8 \\
0 \\
0\end{array}$ & $\begin{array}{l}\qquad 0 \\
8 \\
0 \\
0\end{array}$ & $\begin{array}{l}\frac{n}{n} \\
\frac{n}{n} \\
0\end{array}$ & $\begin{array}{l}\tilde{\emptyset} \\
\varnothing \\
0 \\
0\end{array}$ & 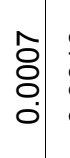 & 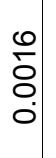 & 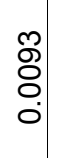 & $\begin{array}{l}\text { N̦} \\
\text { ○ } \\
0\end{array}$ & $\begin{array}{l}\infty \\
\check{\delta} \\
0 \\
0\end{array}$ & $\begin{array}{l}m \\
\bar{\sigma} \\
0 \\
0\end{array}$ & $\begin{array}{l}\text { : } \\
\text { ठ } \\
\text { : }\end{array}$ \\
\hline $\begin{array}{l}\mid \\
\mathbb{U} \\
0\end{array}$ & $\begin{array}{l}\mathbf{E} \\
\mathbf{\Phi} \\
\dot{\omega}\end{array}$ & 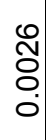 & $\begin{array}{l}9 \\
0 \\
0 \\
0 \\
0\end{array}$ & $\begin{array}{l}\frac{\infty}{f} \\
0 \\
0 \\
0\end{array}$ & $\begin{array}{l}\text { ¿े } \\
\text { ర్ } \\
0 \\
0\end{array}$ & $\begin{array}{l}\text { No } \\
\stackrel{0}{0} \\
0\end{array}$ & $\begin{array}{l}0 \\
\stackrel{0}{0} \\
0 \\
0 \\
0 \\
0\end{array}$ & 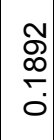 & $\begin{array}{l}0 \\
0 \\
0 \\
0 \\
0\end{array}$ & 1 & $\begin{array}{l}\frac{n}{+} \\
\stackrel{0}{0} \\
\dot{0}\end{array}$ & $\begin{array}{l}\stackrel{10}{ } \\
0 \\
0 \\
0 \\
0\end{array}$ & 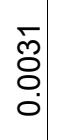 & \begin{tabular}{l}
0 \\
\multirow{2}{*}{} \\
0 \\
0 \\
0
\end{tabular} & $\begin{array}{l}\text { ப் } \\
\text { ¿ } \\
0\end{array}$ & $\begin{array}{l}\text { ô } \\
\text { - } \\
0 \\
0\end{array}$ & $\begin{array}{l}0 \\
0 \\
\varnothing \\
0 \\
0\end{array}$ & 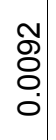 & $\begin{array}{l}\frac{8}{0} \\
\frac{1}{ \pm} \\
\dot{0}\end{array}$ & 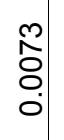 & $\begin{array}{l}\text { లి } \\
\text { ర్ర } \\
0\end{array}$ & 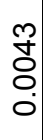 & $\begin{array}{l}0 \\
\vdots \\
0 \\
0\end{array}$ & $\begin{array}{l}\infty \\
0 \\
0 \\
0 \\
0\end{array}$ & 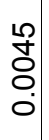 & 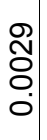 & $\begin{array}{l}\stackrel{0}{\circ} \\
\text { ठ } \\
\circ \\
0\end{array}$ \\
\hline & $\begin{array}{c}\frac{b}{+1} \\
+1\end{array}$ & 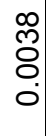 & $\begin{array}{l}0 \\
\vdots \\
0 \\
0 \\
0\end{array}$ & $\begin{array}{l}\stackrel{+}{S} \\
\stackrel{+}{+} \\
0\end{array}$ & $\begin{array}{l}0 \\
\stackrel{0}{2} \\
\stackrel{0}{0}\end{array}$ & 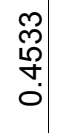 & $\begin{array}{l}\mathscr{\Omega} \\
\stackrel{\sigma}{0} \\
0\end{array}$ & 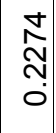 & $\begin{array}{l}\text { } \\
\stackrel{7}{0} \\
0 \\
0\end{array}$ & $\begin{array}{l}\hat{8} \\
\text { Oे } \\
0\end{array}$ & $\begin{array}{l}\text { 号 } \\
\text { ○े } \\
0\end{array}$ & $\begin{array}{l}0 \\
\stackrel{\Lambda}{0} \\
0 \\
0\end{array}$ & $\begin{array}{l}\stackrel{+}{0} \\
\stackrel{0}{0} \\
\dot{0}\end{array}$ & $\begin{array}{l}\overleftarrow{m} \\
\stackrel{0}{0} \\
0 \\
0\end{array}$ & $\begin{array}{l}\bar{\sigma} \\
\overline{8} \\
0 \\
0\end{array}$ & $\begin{array}{l}\mathscr{0} \\
\mathscr{2} \\
0 \\
0 \\
0\end{array}$ & $\begin{array}{l}0 \\
\vdots \\
8 \\
0\end{array}$ & $\begin{array}{l}\hat{L} \\
8 \\
0 \\
0\end{array}$ & 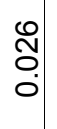 & 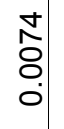 & $\begin{array}{l}\hat{8} \\
8 \\
0 \\
0\end{array}$ & \begin{tabular}{l}
$\widetilde{N}$ \\
ઠे \\
\hdashline
\end{tabular} & 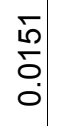 & 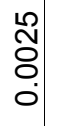 & 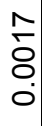 & $\begin{array}{l}\vec{v} \\
\grave{8} \\
\dot{0}\end{array}$ & 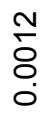 \\
\hline & 岕 & \begin{tabular}{l}
2 \\
\hdashline \\
0 \\
0
\end{tabular} & $\begin{array}{l}\infty \\
\delta \\
0 \\
0\end{array}$ & 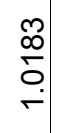 & 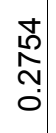 & $\begin{array}{l}\widetilde{N} \\
\text { ?ొ } \\
0\end{array}$ & $\begin{array}{l}\mathcal{N} \\
0 \\
0 \\
0 \\
0\end{array}$ & $\begin{array}{c}\mathcal{N} \\
\tilde{O} \\
0 \\
0\end{array}$ & 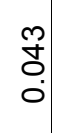 & 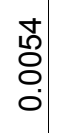 & 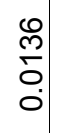 & $\begin{array}{l}\stackrel{10}{0} \\
\stackrel{0}{0} \\
0\end{array}$ & $\begin{array}{l}L \\
\llcorner \\
8 \\
0 \\
0\end{array}$ & $\begin{array}{l}0 \\
0 \\
\varnothing \\
0 \\
0\end{array}$ & $\begin{array}{l}\mathfrak{N} \\
\hat{8} \\
0 \\
0\end{array}$ & $\begin{array}{l}\tilde{y} \\
0 \\
0 \\
0 \\
0\end{array}$ & $\begin{array}{l}\frac{\nabla}{\sigma} \\
\vdots \\
0\end{array}$ & $\begin{array}{l}\bar{N} \\
\bar{\sigma} \\
\vdots\end{array}$ & $\begin{array}{l}\bar{N} \\
\text { Oे } \\
0 \\
0\end{array}$ & $\begin{array}{l}\stackrel{0}{N} \\
\vdots \\
0\end{array}$ & $\begin{array}{l}\overline{8} \\
8 \\
0 \\
0\end{array}$ & $\begin{array}{l}2 \\
\stackrel{2}{ } \\
8 \\
0 \\
0\end{array}$ & 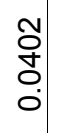 & $\begin{array}{l}\mathbf{J} \\
\vdots \\
0 \\
0\end{array}$ & $\begin{array}{l}\hat{\varphi} \\
\varnothing \\
0 \\
0\end{array}$ & 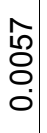 & $\begin{array}{l}\text { N } \\
\text { o } \\
\text { ○. }\end{array}$ \\
\hline \multirow{7}{*}{ 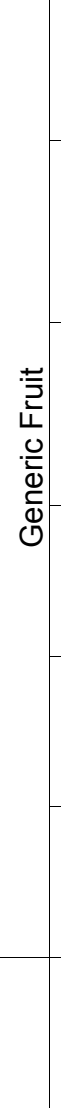 } & $\frac{b}{+1}$ & $\begin{array}{l}\tilde{\delta} \\
\text { ọ } \\
0\end{array}$ & $\begin{array}{l}- \\
8 \\
0 \\
0\end{array}$ & 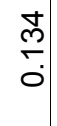 & $\frac{\overline{0}}{0}$ & $\begin{array}{l}\hat{N} \\
\dot{0}\end{array}$ & $\begin{array}{l}\infty \\
\varnothing \\
0 \\
0\end{array}$ & 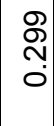 & 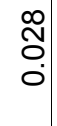 & 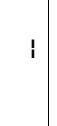 & $\mathbf{i}$ & $\begin{array}{l}\stackrel{1}{0} \\
0 \\
0\end{array}$ & 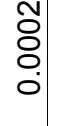 & $\begin{array}{l}\overline{8} \\
0 \\
0\end{array}$ & $\begin{array}{l}\bar{\delta} \\
\dot{0}\end{array}$ & $\begin{array}{l}\check{\sigma} \\
\overline{0} \\
0\end{array}$ & $\mathbf{i}$ & $\mathbf{i}$ & $\begin{array}{l}\bar{\phi} \\
\dot{0}\end{array}$ & 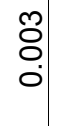 & $\begin{array}{l}5 \\
8 \\
0\end{array}$ & $\begin{array}{l}\overline{8} \\
0\end{array}$ & $\begin{array}{l}\infty \\
\varnothing \\
0 \\
0\end{array}$ & 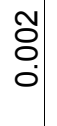 & $\begin{array}{l}5 \\
8 \\
0\end{array}$ & $\begin{array}{l}5 \\
8 \\
0\end{array}$ & 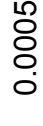 \\
\hline & 蒙 & $\begin{array}{l}\bar{\delta} \\
\dot{0} \\
\dot{0}\end{array}$ & $\begin{array}{l}5 \\
8 \\
0\end{array}$ & $\begin{array}{l}8 \\
\stackrel{\infty}{0} \\
\circ\end{array}$ & 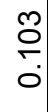 & $\stackrel{\mathscr{m}}{\stackrel{0}{\circ}}$ & 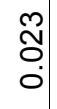 & 会 & $\begin{array}{l}\widehat{\sigma} \\
\delta \\
0\end{array}$ & 1 & $i$ & $\begin{array}{c}\text { ల్ } \\
0 \\
0\end{array}$ & $\begin{array}{l}\bar{\partial} \\
\dot{0}\end{array}$ & $\begin{array}{l}\bar{\delta} \\
\text { ¿ }\end{array}$ & $\begin{array}{l}\overline{8} \\
0 \\
0\end{array}$ & $\begin{array}{l}\infty \\
0 \\
0\end{array}$ & 1 & 1 & $\begin{array}{l}\mathscr{8} \\
\text { О } \\
0\end{array}$ & 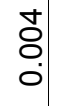 & $\begin{array}{l}5 \\
8 \\
0\end{array}$ & 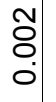 & $\begin{array}{l}\sigma \\
\check{0} \\
0\end{array}$ & $\begin{array}{l}8 \\
8 \\
0 \\
0\end{array}$ & 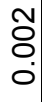 & $\begin{array}{l}5 \\
8 \\
0\end{array}$ & 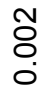 \\
\hline & $\frac{0}{+1}$ & $\begin{array}{l}\mathbb{N} \\
\delta \\
0 \\
0\end{array}$ & $\begin{array}{l}5 \\
8 \\
0\end{array}$ & \begin{tabular}{l}
0 \\
\multirow{N}{*}{} \\
0
\end{tabular} & 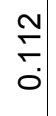 & $\frac{\stackrel{n}{\sim}}{\grave{0}}$ & $\begin{array}{l}N \\
\check{0} \\
0\end{array}$ & $\begin{array}{c}n \\
\stackrel{1}{N} \\
0\end{array}$ & $\begin{array}{l}0 \\
\vdots \\
\vdots \\
0\end{array}$ & 1 & 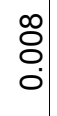 & $\begin{array}{l}\stackrel{1}{0} \\
0 \\
0 \\
0\end{array}$ & $\begin{array}{l}\overline{8} \\
8 \\
0 \\
0\end{array}$ & $\begin{array}{l}\overline{8} \\
0 \\
\end{array}$ & $\begin{array}{l}\overline{8} \\
0 \\
0\end{array}$ & $\begin{array}{l}\infty \\
\check{0} \\
0\end{array}$ & $\mathrm{i}$ & $\begin{array}{l}m \\
\varnothing \\
0 \\
0\end{array}$ & $\begin{array}{l}\text { O) } \\
\stackrel{0}{\circ}\end{array}$ & $\begin{array}{l}\text { ¿े } \\
\text { ठ }\end{array}$ & $\begin{array}{l}\overline{8} \\
0 \\
0\end{array}$ & $\begin{array}{l}\overline{8} \\
\\
\end{array}$ & $\begin{array}{l}\hat{o} \\
0 \\
0\end{array}$ & 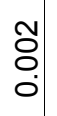 & $\begin{array}{l}\overline{8} \\
0 \\
0\end{array}$ & $\begin{array}{l}\overline{8} \\
\\
0\end{array}$ & $\begin{array}{l}\overline{8} \\
\circ \\
\end{array}$ \\
\hline & $\begin{array}{l}\frac{E}{\Phi} \\
\dot{\omega}\end{array}$ & 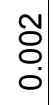 & $\begin{array}{l}5 \\
8 \\
0\end{array}$ & $\begin{array}{l}1 \\
\stackrel{0}{0} \\
0 \\
0\end{array}$ & $\frac{N}{\circ}$ & $\frac{\overline{6}}{\grave{0}}$ & $\begin{array}{l}0 \\
\vdots \\
0 \\
0\end{array}$ & $\mid \begin{array}{c}1 \\
\text { م } \\
\tilde{m} \\
0\end{array}$ & $\begin{array}{l}0 \\
\tilde{0} \\
0 \\
0\end{array}$ & 1 & $\begin{array}{l}0 \\
\\
0 \\
0\end{array}$ & $\begin{array}{l}0 \\
\stackrel{0}{0} \\
0 \\
0\end{array}$ & 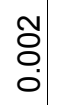 & 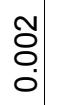 & \begin{tabular}{l}
$\widetilde{\jmath}$ \\
రิ \\
\hdashline
\end{tabular} & $\begin{array}{l}\text { ల్రి } \\
0 \\
0\end{array}$ & $\begin{array}{l}m \\
8 \\
0\end{array}$ & $\begin{array}{l}0 \\
8 \\
0 \\
0\end{array}$ & 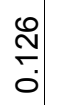 & \begin{tabular}{l}
0 \\
\hdashline \\
0 \\
0
\end{tabular} & $\begin{array}{l}\text { ָे } \\
\varnothing \\
0\end{array}$ & \begin{tabular}{l}
$m$ \\
$\varnothing$ \\
\hdashline
\end{tabular} & $\begin{array}{l}0 \\
0 \\
0 \\
0\end{array}$ & 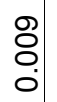 & $\begin{array}{l}\mathcal{N} \\
\delta \\
\\
0\end{array}$ & 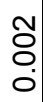 & $\begin{array}{l}\text { ठ } \\
\text { ठ } \\
\end{array}$ \\
\hline & $\frac{b}{+1}$ & $\begin{array}{l}8 \\
8 \\
0 \\
0\end{array}$ & $\bar{\delta}$ & \begin{tabular}{l}
\multirow{f}{*}{} \\
$\stackrel{0}{0}$
\end{tabular} & $\begin{array}{l}\mathbb{0} \\
\varnothing \\
0 \\
0\end{array}$ & $\begin{array}{c}\mathscr{m} \\
\stackrel{2}{0} \\
0 \\
0\end{array}$ & $\begin{array}{l}\text { సิ } \\
0 \\
0\end{array}$ & $\frac{\mathscr{Q}}{\circ}$ & $\begin{array}{l}8 \\
\dot{0} \\
\dot{0}\end{array}$ & 1 & $\begin{array}{l}0 \\
0 \\
0 \\
0\end{array}$ & $\begin{array}{l}\infty \\
0 \\
0 \\
0 \\
0\end{array}$ & $\begin{array}{l}\overline{8} \\
\vdots \\
0\end{array}$ & $\begin{array}{l}2 \\
0 \\
0 \\
0\end{array}$ & $\begin{array}{l}\text { 尺े } \\
0 \\
0\end{array}$ & $\begin{array}{l}\text { பे } \\
0 \\
0\end{array}$ & $\begin{array}{l}+ \\
\\
0\end{array}$ & $\begin{array}{l}\sigma \\
\\
0\end{array}$ & $\begin{array}{l}\stackrel{L}{0} \\
0 \\
0\end{array}$ & $\begin{array}{l}0 \\
\stackrel{0}{0} \\
0\end{array}$ & $\begin{array}{l}\overline{8} \\
0 \\
0\end{array}$ & 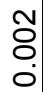 & $\begin{array}{l}\text { స్ } \\
0 \\
0\end{array}$ & $\begin{array}{l}\text { ठ } \\
0 \\
0\end{array}$ & $\begin{array}{l}\widetilde{N} \\
\text { రి } \\
0\end{array}$ & 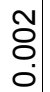 & $\begin{array}{l}\text { §̊ } \\
\text { ठ. }\end{array}$ \\
\hline & 离 & $\begin{array}{l}\hat{8} \\
0 \\
0\end{array}$ & $\mid \begin{array}{l}\widetilde{N} \\
0 \\
0 \\
0\end{array}$ & $\begin{array}{l}\stackrel{0}{R} \\
\stackrel{R}{0} \\
0\end{array}$ & $\underset{⿱ ⺊ 口}{+}$ & $\begin{array}{c}\text { ले } \\
\text { o. }\end{array}$ & $\begin{array}{l}\dddot{0} \\
\stackrel{0}{0} \\
.\end{array}$ & $\mid$\begin{tabular}{c}
$\infty$ \\
\multirow{L}{0}{} \\
0 \\
0
\end{tabular} & $\begin{array}{l}10 \\
\vdots \\
0 \\
0\end{array}$ & 1 & 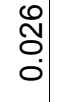 & $\begin{array}{l}\mathscr{m} \\
0 \\
0 \\
0 \\
0\end{array}$ & $\begin{array}{l}\hat{0} \\
0 \\
0\end{array}$ & $\begin{array}{l}\hat{\circ} \\
0 \\
\circ\end{array}$ & $\begin{array}{l}\stackrel{8}{0} \\
\stackrel{0}{0} \\
\dot{0}\end{array}$ & \begin{tabular}{l}
$\infty$ \\
\hdashline \\
0
\end{tabular} & 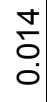 & $\begin{array}{l}0 \\
\vdots \\
0 \\
0\end{array}$ & $\begin{array}{l}\hat{f} \\
\text { Oे. }\end{array}$ & $\stackrel{m}{\circ}$ & $\begin{array}{l}\infty \\
8 \\
\\
0\end{array}$ & $\begin{array}{l}0 \\
0 \\
0 \\
0\end{array}$ & $\begin{array}{l}0 \\
\stackrel{0}{0} \\
0 \\
0\end{array}$ & $\begin{array}{l}\overline{0} \\
\text { Oे } \\
\end{array}$ & $\begin{array}{l}\infty \\
\stackrel{0}{ } \\
\text { ○े }\end{array}$ & $\begin{array}{l}\infty \\
8 \\
0 \\
0\end{array}$ & $\begin{array}{l}10 \\
0 \\
0\end{array}$ \\
\hline & 这 & $\bar{\alpha}$ & $\overline{\mathbf{m}}$ & తే & $\bar{u}$ & $\sum^{\infty}$ & $\Sigma^{\Sigma}$ & 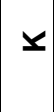 & $\frac{\pi}{2}$ & $i=$ & $>$ & $\frac{0}{4}$ & $\widetilde{J}$ & $\Xi$ & ఱ్ & $\frac{\pi}{z}$ & $\boldsymbol{D}$ & $\stackrel{0}{\nu}$ & के & $\tilde{\boldsymbol{\Phi}}$ & نे & $\mathcal{u}$ & $\bar{u}$ & ن & జّ & $\frac{\mathbb{1}}{\mathbf{1}}$ & 亡ّ \\
\hline
\end{tabular}




\begin{tabular}{|c|c|c|c|c|c|c|c|c|c|c|c|}
\hline \multirow{6}{*}{ 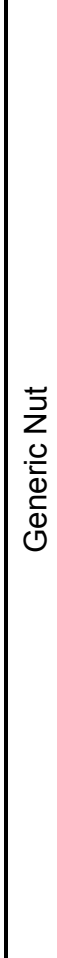 } & $\frac{b}{+1}$ & 1 & $\begin{array}{l}\bar{m} \\
\stackrel{m}{\tilde{c}} \\
0\end{array}$ & $\begin{array}{l}\underset{\tilde{N}}{\Delta} \\
0 \\
0\end{array}$ & $\begin{array}{l}12 \\
8 \\
0 \\
0 \\
0\end{array}$ & 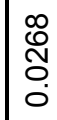 & $\begin{array}{c}N \\
\check{\delta} \\
\check{O} \\
\dot{0}\end{array}$ & $\begin{array}{l}0 \\
\\
\\
0\end{array}$ & $\begin{array}{l}8 \\
8 \\
0 \\
0\end{array}$ & $\begin{array}{l}\hat{m} \\
\tilde{O} \\
0\end{array}$ & 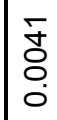 \\
\hline & $\frac{ \pm}{\mathbf{z}}$ & i & $\begin{array}{l}\mathbb{N} \\
\stackrel{2}{2} \\
\stackrel{0}{0}\end{array}$ & $\frac{\mathfrak{N}}{\check{\sigma}}$ & 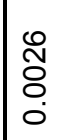 & సิ & 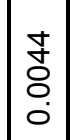 & 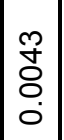 & 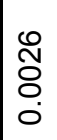 & $\begin{array}{l}0 \\
\stackrel{\rho}{+} \\
\leftarrow \\
0\end{array}$ & $\begin{array}{l}0 \\
8 \\
0 \\
0\end{array}$ \\
\hline & $\frac{b}{+1}$ & $\begin{array}{l}9 \\
\stackrel{9}{0} \\
8 \\
0\end{array}$ & $\begin{array}{l}\bar{o} \\
\stackrel{0}{\leftarrow} \\
0\end{array}$ & $\begin{array}{l}\text { Pी } \\
\text { Oे } \\
0 \\
0\end{array}$ & $\begin{array}{l}5 \\
\dot{0} \\
0\end{array}$ & 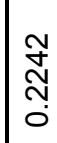 & 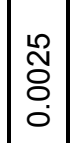 & \begin{tabular}{|l|}
0 \\
0 \\
0 \\
0 \\
0
\end{tabular} & 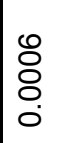 & $\begin{array}{l}\hat{O} \\
\mathcal{N} \\
0 \\
0\end{array}$ & $\begin{array}{l}\infty \\
0 \\
0 \\
0 \\
0\end{array}$ \\
\hline & $\begin{array}{l}\varepsilon \\
\Phi \\
\dot{\Phi}\end{array}$ & $\begin{array}{l}\hat{8} \\
0 \\
0\end{array}$ & $\begin{array}{l}\stackrel{\grave{N}}{N} \\
\vdots \\
0\end{array}$ & 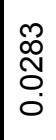 & $\begin{array}{l}\overline{5} \\
8 \\
0 \\
0\end{array}$ & 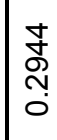 & $\left|\begin{array}{c}\hat{m} \\
\delta \\
0 \\
0\end{array}\right|$ & $\begin{array}{l}\infty \\
0 \\
0 \\
0\end{array}$ & 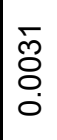 & \begin{tabular}{|l} 
lo \\
0 \\
0 \\
0 \\
0 \\
0
\end{tabular} & 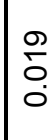 \\
\hline & $\frac{b}{+1}$ & $\begin{array}{l}\overline{8} \\
0 \\
0 \\
0\end{array}$ & \begin{tabular}{|c|c}
$\hat{0}$ \\
0 \\
0 \\
0 \\
0
\end{tabular} & 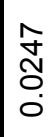 & $\frac{m}{8}$ & 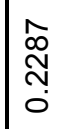 & $\left|\begin{array}{l}\stackrel{2}{N} \\
0 \\
0 \\
0\end{array}\right|$ & \begin{tabular}{|l|}
$\hat{y}$ \\
0 \\
0 \\
$\dot{0}$
\end{tabular} & $\begin{array}{l}\mathscr{8} \\
\varnothing \\
0\end{array}$ & 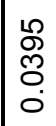 & 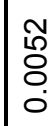 \\
\hline & 离 & $\begin{array}{l}\text { ட̊ } \\
8 \\
8 \\
0 \\
0\end{array}$ & $\begin{array}{l}\overline{0} \\
\stackrel{N}{N} \\
0\end{array}$ & 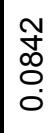 & $\mid \begin{array}{l}\frac{\pi}{0} \\
\frac{\pi}{0}\end{array}$ & 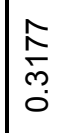 & $\left|\begin{array}{l}0 \\
\hat{\circ} \\
0 \\
0\end{array}\right|$ & $\begin{array}{l}\mathscr{0} \\
\ddot{0} \\
0 \\
0\end{array}$ & \begin{tabular}{l}
1 \\
\hdashline \\
$\varnothing$ \\
0 \\
0 \\
0
\end{tabular} & $\frac{\tilde{\sigma}}{\tilde{\sigma}}$ & $\begin{array}{l}\mathscr{0} \\
0 \\
0 \\
0\end{array}$ \\
\hline \multirow{7}{*}{ 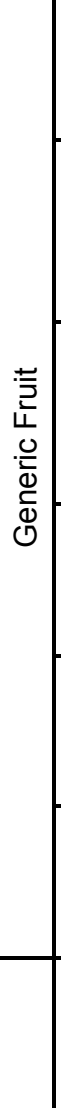 } & $\frac{b}{+1}$ & 1 & 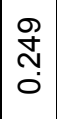 & 贷 & 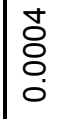 & \begin{tabular}{l}
$\infty$ \\
\multirow{2}{0}{} \\
0 \\
0
\end{tabular} & $\begin{array}{l}\bar{\delta} \\
\circ \\
0\end{array} \mid$ & 1 & 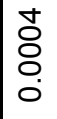 & 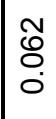 & I \\
\hline & 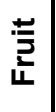 & 1 & $\begin{array}{l}\stackrel{8}{0} \\
\stackrel{0}{0} \\
0\end{array}$ & $\frac{1}{5}$ & 훙 & $\begin{array}{l}\infty \\
0 \\
0 \\
0 \\
0\end{array}$ & 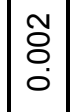 & $i$ & $\begin{array}{l}8 \\
8 \\
\\
0 \\
0\end{array}$ & $\frac{\hat{m}}{\leftarrow}$ & I \\
\hline & $\frac{b}{+1}$ & I & 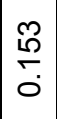 & 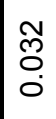 & $\begin{array}{l}1 \\
0 \\
8 \\
0 \\
0\end{array}$ & $\frac{0}{0}$ & $\left|\begin{array}{l}\overline{8} \\
\circ \\
0\end{array}\right|$ & $\overline{8}$ & 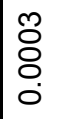 & $\begin{array}{l}0 \\
0 \\
0 \\
0\end{array}$ & i \\
\hline & $\begin{array}{l}\varepsilon \\
\Phi \\
\dot{\omega}\end{array}$ & $\mathrm{I}$ & $\begin{array}{l}0 \\
0 \\
0 \\
0\end{array}$ & ô. & \% & ָ̃ & $\begin{array}{l}\dddot{0} \\
\delta \\
0 \\
0\end{array}$ & $\begin{array}{l}0 \\
\delta \\
0 \\
0\end{array}$ & 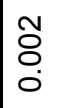 & $\frac{\hat{\theta}}{0}$ & 1 \\
\hline & $\frac{b}{+1}$ & $\begin{array}{l}\tilde{0} \\
0\end{array}$ & 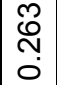 & 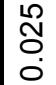 & 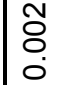 & $\begin{array}{l}\infty \\
\infty \\
\leftarrow \\
\vdots\end{array}$ & $\begin{array}{l}\mathbf{Z} \\
0 \\
0 \\
0\end{array}$ & \begin{tabular}{|l|}
0 \\
0 \\
0
\end{tabular} & $\begin{array}{l}\bar{\delta} \\
\circ \\
0\end{array}$ & $\begin{array}{l}\overline{5} \\
0 \\
0 \\
0\end{array}$ & 占 \\
\hline & 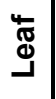 & $\begin{array}{l}0 \\
0 \\
0 \\
0\end{array}$ & 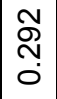 & $\mid \begin{array}{l}\infty \\
0 \\
0\end{array}$ & 吕 & \begin{tabular}{l} 
¿ \\
\multirow{2}{*}{} \\
0
\end{tabular} & $\mid \begin{array}{l}8 \\
\circ \\
0 \\
0\end{array}$ & $\begin{array}{l}8 \\
0 \\
0 \\
0\end{array}$ & $\begin{array}{l}\infty \\
0 \\
0 \\
0\end{array}$ & $\mid \begin{array}{l}8 \\
0 \\
0\end{array}$ & 范 \\
\hline & $\begin{array}{l}\frac{\bar{\Phi}}{\Phi} \\
\frac{\varepsilon}{\Phi} \\
\frac{\Phi}{\Psi}\end{array}$ & $\mathbf{z}$ & $\overline{\mathbf{z}}$ & $\frac{0}{\underline{x}}$ & 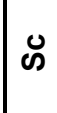 & ఉ & $\stackrel{\pi}{\bullet}$ & $\stackrel{\rho}{F}$ & $\stackrel{F}{F}$ & $\frac{\tilde{N}}{2}$ & $\bar{N}$ \\
\hline
\end{tabular}





\subsection{SUMMARY AND CONCLUSIONS}

Several of the elements reported in the tables in Section $4(\mathrm{Ca}, \mathrm{Cl}, \mathrm{Mg}, \mathrm{K}, \mathrm{Na})$ are well known macronutrients. These have relatively high transfer factors (with the exception of $\mathrm{Na}$ ); however, these may all be homeostatically regulated as discussed in Section 2.2. It is apparent that these macronutrients are preferentially taken up from soils. Several other elements $(\mathrm{Mn}, \mathrm{Cr}$, $\mathrm{Co}, \mathrm{Fe}, \mathrm{Ni}, \mathrm{Zn}$ ) are micronutrients. The average uptake of the micronutrients is about one-fifth that of the average macronutrient. Both sets of nutrient classes have higher uptakes than those of the remaining trace elements, as would be expected. In addition, for the macronutrients and micronutrients, the average uptakes in leaves are greater than in stems, which in turn are greater than in fruits/nuts. In the other non-essential elements, the uptake in leaves and stems are about equal, but both are still greater than in fruits/nuts. Thus, it appears that the plants are using the nutrients in photosynthesis and respiration, but not storing them in the fruits.

Some observations may be made about the use of 'surrogate' elements for others with few or no measurements. It is often asserted that strontium can be expected to mimic calcium and that cesium can be expected to mimic potassium. In this series of measurements, the transfer factors for cesium are quite unlike those for potassium. Potassium uptake factors are high and very similar across the plant compartments, but the cesium uptake factors are much lower (nearly a factor of 50) and show non-essential-element discrimination between leaves, stems, and fruits. (The transfer factors for sodium, also a member of period I-A of the periodic table, are not comparable to potassium and cesium.) The transfer of calcium is also high and shows slight decrease from leaf to stem to fruit; strontium has the same pattern but the transfer is lower than that for calcium by about a factor of 4 . (The transfer factors for magnesium, also a member of periodic table II-A, are more similar to strontium than to calcium.) The limited information about chemical periods $\mathrm{V}$-B (As and $\mathrm{Sb}$ ) and $\mathrm{VIII}-\mathrm{A}$ (Fe, Co, and $\mathrm{Ni}$ ) also does not indicate a strong influence of chemical similarity, although this may be because of the mixed influences of the micronutrients in these categories.

The members of the lanthanide series are also assumed to behave similarly because of chemical similarity. For instance, in the GENII computer code data library (Napier et al. 2012), many lanthanide transfer factors are assumed to parallel that of cerium, and in these experiments that assumption appears to be more defensible. The measurements for $\mathrm{Nd}, \mathrm{Sm}$, $\mathrm{Eu}, \mathrm{Tb}, \mathrm{Yb}$, and $\mathrm{Lu}$ are all relatively similar. The only actinide elements in this experimental series are Th and $U$, and the lack of significance of the $U$ measurements makes any comparison difficult. Overall, chemical similarity may be appropriate for larger-atomic-radius, non-essential elements, but potentially misleading for analogues for homeostatically-controlled nutrients.

The generic transfer factors developed in this report may be implemented in radioecological and biosphere models, such as GENII (Napier et al. 2012). The transfer factors for various specific fruit and nut varieties developed in this report may be useful in the development of models for tree fruits. The results indicate that, overall, transfer is highest to leaves, medium to the woody stems, and lowest to fruits and nuts. 



\subsection{REFERENCES}

Antonopoulos-Domis M, Clouvas A, Gagianas A. 1990. Compartment model for long-term contamination prediction in deciduous fruit trees after a nuclear accident. Health Physics 58(6):737-741.

ASA (American Society of Agronomy). 1982. Methods of Soil Analysis. Part 2, Chemical and Microbiological Properties. SSSA Book Series 9 (Part 2), AL Page (ed.), Soil Science Society of America, Madison, Wisconsin.

ASTM (American Society for Testing and Materials). 1998. Method D2216-98. Standard Test Method for Laboratory Determination of Water (Moisture) Content of Soil and Rock by Mass. American Society for Testing and Materials, West Conshohocken, Pennsylvania.

ASTM (American Society for Testing and Materials). 2000. Method D1140-00. Standard Test Methods for Amount of Material in Soils Finer Than the No. 200 (75 $\mu \mathrm{m})$ Sieve. American Society for Testing and Materials, West Conshohocken, Pennsylvania.

ASTM (American Society for Testing and Materials). 2001. Method E1915-01. Test Methods for Analysis of Metal Bearing Ores and Related Materials by Combustion Infrared Absorption Spectrometry. American Society for Testing and Materials, West Conshohocken, Pennsylvania.

ASTM (American Society for Testing and Materials). 2003. Method D422-63. Standard Test Method for Particle-Size Analysis of Soils (Revised 1998). American Society for Testing and Materials, West Conshohocken, Pennsylvania.

Burton CA, Pratt MW. 1968. Prediction of the maximum dosage to man from the fallout of nuclear devices III.Biological Guidelines for Device Design. UCRL-50163 Pt. III. Lawrence Radiation Laboratory, Livermore, California.

Carini F, Bengtsson G. 2001. "Post-deposition transport of radionuclides in fruit," J. Environ. Radioact. 52:215-236.

Cataldo DA, Wildung RE, Garland TR. 1983. "Root Absorption and Transport Behavior of Technetium in Soybean", Plant Physiol. 73(3): 849-852.

Centofani T, Penfield R, Albrecht A, Pellerin S, Fluhler H, Frossard E. 2005. "Is the Transfer Factor a Relevant Tool to Assess the Soil-to-Plant Transfer of Radionuclides under Field Conditions?" J. Env. Quality 34(6): 1972-1979.

Coughtrey PC, Thorne MC. 1983. Radionuclide Distribution and Transport in Terrestrial and Aquatic Ecosystems, a Critical Review of Data. Vols. 1-6. AA Balkema, Rotterdam.

Coughtrey PJ, Carini F, Venter A. 2001. "Conclusions and recommendations", Journal of Environmental Radioactivity 52:309-314. 
Dahlman RC, van Voris P. 1976. "Cycling of ${ }^{137}$ Cs in Soil and Vegetation of a Flood Plain 30 Years after Initial Contamination," in Cushing CE (Ed.). Radioecology and Energy Resources, Dowden, Hutchinson, and Ross, Inc. Stroudsburg, Pennsylvania.

Department of Energy (DOE). 1997. Columbia River Comprehensive Impact Assessment. U.S. Department of Energy, Richland Operations, Richland, Washington.

Eisenbud M. 1987. Environmental Radioactivity from Natural, Industrial and Military Sources. 3rd Edition, Academic Press, New York.

Faw RE, Shultis JK. 1999. Radiological Assessment: Sources and Doses. American Nuclear Society, La Grange Park, Illinois.

Fletcher JF, Dotson WL. 1971. HERMES - A Digital Computer Code for Estimating Regional Radiological Effects from the Nuclear Power Industry, HEDL-TME-71-168, Hanford Engineering Development Laboratory, Richland, Washington.

Förstner U, Wittmann GTW. 1981. Metal pollution in the aquatic environment. SpringerVerlag, Berlin, Germany.

Frissel MJ. 1994. "A homeostatic partly dynamic model for ${ }^{137}$ Cs in trees." In Soil-plant relationships. Proceedings of the XXIVth Annual ESNA/IUR Meeting. September 12-16, 1994, Varna, Bulgaria. OEFZS-4728, Austria: Forschungszentrum Seibersdorf.

Glascock, M. D. (2006) Tables for Neutron Activation Analysis (6 $6^{\text {th }}$ Edition). University of Missouri Research Reactor Center (MURR), Columbia.

Grummitt WE. 1976. "Transfer fo Cobalt-60 to Plants from Soils Treated with Sewage Sludge," in Cushing CE (Ed.). Radioecology and Energy Resources, Dowden, Hutchinson, and Ross, Inc. Stroudsburg, Pennsylvania.

Harju, L., J. Rajander, K-E. Saarela, J-O. Lill, S-J. Heselius, and A. Lindroos (2004) Losses of elements during dry ashing of biological materials. $10^{\text {th }}$ International Conference of Particle Induced X-ray Emission and its Analytical Applications, PIXE 2004, Portoroz, Slovenia, June 48, 2004. Http://pixe2004.ijs.si/.

International Atomic Energy Agency (IAEA). 1982. Generic Models and Parameters for Assessing the Environmental Transfer of Radionuclides from Routine Releases, Safety Series No. 57, International Atomic Energy Agency, Vienna.

International Atomic Energy Agency (IAEA). 1994. Handbook of Parameter Values for the Prediction of Radionuclide Transfer in Temperate Environments, Technical Report Series No. 364, International Atomic Energy Agency, Vienna.

International Atomic Energy Agency (IAEA). 1995. Validation of models using Chernobyl fallout data from the Central Bohemia region of the Czech Republic-Scenario CB. First Report of the VAMP Multiple Pathways Assessment Working Group. IAEA-TECDOC-795, International Atomic Energy Agency, Vienna. 
International Atomic Energy Agency (IAEA). 1996. Validation of models using Chernobyl fallout data from southern Finland-Scenario S. Second Report of the VAMP Multiple Pathways Assessment Working Group. IAEA-TECDOC-904. International Atomic Energy Agency, Vienna.

International Atomic Energy Agency (IAEA). 2004. Quantifying uncertainty in nuclear analytical measurements, IAEA-TECDOC-1401. International Atomic Energy Agency, Vienna.

International Atomic Energy Agency (IAEA). 2009. Quantification of Radionuclide Transfer in terrestrial and Freshwater Environments for Radiological Assessments, IAEA TECDOC Series No. 1616, International Atomic Energy Agency, Vienna.

International Atomic Energy Agency (IAEA). 2010. Handbook of Parameter Values for the Prediction of Radionuclide Transfer in Terrestrial and Freshwater Environments, IAEA Technical Reports Series No. 472, International Atomic Energy Agency, Vienna.

International Union of Radioecologists (IUR). 1989. VI ${ }^{\text {th }}$ Report of the Working Group Soil-toPlant Transfers, IUR, Bilthoven, The Netherlands.

Johnson, DM, PR Hooper, and RM Conrey. 1999. "XRF Analysis of Rocks and Minerals for Major and Trace Elements on a Single Low Dilution Li-tetraborate Fused Bead. Advances in X-ray Analysis, Vol. 41, JV Gilfrich TC Huang, CR Hubbard, IC Noyan, PK Predecki, DK Smith, and RL Snyder (eds.), p. 843-867. International Centre for Diffraction Data (ICDD), Newtown Square, Pennsylvania.

Kennedy WE Jr, Strenge DL. 1992. Residual Radioactive Contamination from Decommissioning: Technical Basis for Translating Contamination Levels to Annual Total Effective Dose Equivalent, Vol. 1. NUREG/CR-5512, U.S. Nuclear Regulatory Commission, Washington, D.C.

Koh, S., T. Aoki, Y. Katayama, J. Takada (1999) Losses of elements in plant samples under the dry ashing process. Journal of Radioanalytical and Nuclear Chemistry, Vol. 239, No. 3, 591594.

Miller CW, Baes C F III, Dunning DE Jr, Etnier EL, Kanak KK, Kocher DC, Little CA, McDowell-Boyer LM, Meyer HR, Rupp EM, Shor RW. 1980. Recommendations Concerning Models and Parameters Best Suited to Breeder Reactor Environmental Radiological Assessments. ORNL-5529. Oak Ridge National Laboratory, Oak Ridge, Tennessee.

Ministry of Agriculture, Fisheries, and Food (MAFF). 1999. Guidance for Assessing the Potential Impact of Radionuclide Discharges to the Environment, Joint Food Safety and Standards Group, Department of Health, London, England.

Mitchell NG. 2001. Models for radionuclide transfer to fruits and data requirements. Journal of Environmental Radioactivity, Vol. 52, No. 2-3, 291-307.

Napier BA, KM Krupka, MM Valenta, and TJ Gilmore. 2005. Soil and Groundwater Sample Characterization and Agricultural Practices for Assessing Food Chain Pathways in Biosphere Models . NUREG/CR-6881, PNNL-15244, Pacific Northwest National Laboratory, Richland, WA. 
Napier BA. 2006. Alternative Conceptual Models for Assessing Food Chain Pathways in Biosphere Models, NUREG/CR-6910, PNNL-15872, US Nuclear Regulatory Commission, Washington, DC.

Napier BA, DL Strenge, JV Ramsdell, Jr, PW Eslinger, and CJ Fosmire. 2012. GENII Version 2 Software Design Document. PNNL-14584 Rev.4, Pacific Northwest National Laboratory, Richland, WA.

National Council on lonizing Radiation and Protection (NCRP). 1984. Radiological Assessment: Predicting the Transport, Bioaccumulation, and Uptake by Man of Radionuclides Released to the Environment. NCRP Report No. 76, Bethesda, MD.

National Council on lonizing Radiation and Protection (NCRP). 1996. Screening Models for Releases of Radionuclides to Atmosphere, Surface Water and Ground. NCRP Report No. 123, Vol. I., Bethesda, MD.

$\mathrm{Ng}$ YC, Thompson SE. 1966. Prediction of the Maximum Dosage to Man from the Fallout of Nuclear Devices II. Estimation of the Maximum Dose from Internal Emitters, UCRL-50163 Part II, University of California Radiation Laboratory, Livermore, California.

Ng YC, Burton CA, Thompson SE, Tandy RK, Kretner HK, Pratt MW. 1968. Prediction of the maximum dosage to man from the fallout of nuclear devices IV. Handbook for Estimating the Maximum Internal Dose from Radionuclides Released to the Biosphere. UCRL-50163 Pt. IV. Lawrence Radiation Laboratory, Livermore, California.

$\mathrm{Ng}$ YC, Colsher CS, Thompson SE. 1982. Soil-to-Plant Concentration Factors for Radiological Assessments: Final Report. NUREG/CR-2975, US Nuclear Regulatory Commission, Washington, DC.

Peterson HT Jr. 1983. "Terrestrial and Aquatic Food Chain Pathways," in Till JE, Meyer HR. Radiological Assessment, A Textbook on Environmental Dose Analysis, NUREG/CR-3332, US Nuclear Regulatory Commission, Washington, DC.

Sheppard MI, Sheppard SC. 1985. "The Plant Concentration Ratio Concept as Applied to Natural U." Health Physics 48:494-500.

Stannard JN. 1988. Radioactivity and Health, A History. DOE/RL/01830-T59, Pacific Northwest Laboratory, Richland, Washington.

Staven LH, Napier BA, Rhoads K, Strenge DL. 2003. A Compendium of Transfer Factors for Agricultural and Animal Products. PNNL-13421.Pacific Northwest National Laboratory, Richland, Washington.

Tamplin AR. 1967. Prediction of the maximum dosage to man from the fallout of nuclear devices. I. Estimation of the maximum contamination of agricultural land. UCRL-50163 Pt. I. Lawrence Radiation Laboratory, Livermore, California.

Thorne MC, Coughtrey PJ. 1983. "Dynamic models for radionuclide transport in soils, plants and domestic animals." In: Coughtrey PJ, Bell JNB, Roberts TM, Ecological aspects of radionuclide release (pp. 127-139). Oxford: Blackwell Scientific Publications. 
United Nations Scientific Committee on the Effects of Atomic Radiation (UNSCEAR). 2000. Sources and Effects of lonizing Radation, Vol. 1: Sources, UNSCEAR 2000 Report to the General Assembly, with Scientific Annexes, United Nations, New York.

U.S. Nuclear Regulatory Commission (NRC). 1977. Calculation of Annual Doses to Man from Routine Releases of Reactor Effluents for the Purpose of Evaluating Compliance with 10 CFR 50 Appendix I, Regulatory Guide 1.109, Nuclear Regulatory Commission Office of Standards Development, Washington, DC.

Ventner A, Coughtrey PJ, Carini F, Inoue Y. 2001. "Foreword," Journal of Environmental Radioactivity, 52:309-314.

Whicker FW, Schultz V. 1982. Radioecology: Nuclear Energy and the Environment. CRC Press, Boca Raton, Florida. Vol. I: 212 pp; Vol. II: 228 pp.

Wolterbeek HT, van der Meer AJ, Dielemans U. 2000. "On the variability of plant bioconcentration factors (BCF) of environmental radionuclides: a case study on the effects of surface film and free space on the interpretation of ${ }^{99 \mathrm{~m}} \mathrm{TcO}_{4}{ }^{-}$sorption in duckweed." Sci Total Environ. 257(2-3):177-90.

Wang Y-Y, Biwer BM, Yu C. 1993. A Compilation of Radionuclide Transfer Factors for the Plant, Meat, Milk, and Aquatic Food Pathways and the Suggested Default Values for the RESRAD Code. ANL/EAIS/TM-103, Argonne National Laboratory, Argonne, Illinois.

Yu C, AJ Zielen, J-J Cheng, DJ Lepoire, E Gnanapragasam, S Kambof, J Arnish, A Wallo III, WA Williams and H Peterson. 2001. User's Manual for RESRAD Version 6, ANL/EAD-4. Argonne National Laboratory, Argonne, Illinois. 



\section{APPENDIX A. RESULTS OF ANALYSES AND CHARACTERIZATION OF SOIL, CROP, AND FRUIT SAMPLES}

Instrumental Neutron Activation Analysis (INAA) was used to determine the concentrations of trace elements in the samples. Concentrations for 35 elements (Al, As, Ba, Br, Ca, Ce, Cl, Co, Cr, Cs, Eu, Fe, Hf, K, La, Lu, Mg, Mn, Na, Nd, Ni, Rb, Sb, Sc, $\mathrm{Sm}, \mathrm{Sr}, \mathrm{Ta}, \mathrm{Tb}, \mathrm{Th}, \mathrm{Ti}, \mathrm{U}, \mathrm{V}, \mathrm{Yb}, \mathrm{Zn}$, and $\mathrm{Zr}$ ) are presented in Table A.1. All values are reported in parts per million (ppm); associated error values reflect counting uncertainty ( \pm 1 sigma) for net peak areas. Note that less-than $(<)$ values indicate concentrations below detection limits; the value given represents the minimum detectable concentration (MDC) and varies according to the continuum or background in the region of the peak in question, which in turn is a function of sample matrix composition.

Detection limits vary strongly by isotope, and are a function of activation yield and gamma branching ratios. In spite of the preconcentration via dry ashing, many elements were below detection limits for a significant number of cases. Only 17 elements were detected in at least $90 \%$ of the cases, while two others were detected in $87 \%$ of cases; this suite includes $\mathrm{Al}, \mathrm{Ca}, \mathrm{Cl}, \mathrm{Co}, \mathrm{Cr}, \mathrm{Cs}, \mathrm{Fe}, \mathrm{K}, \mathrm{La}, \mathrm{Mg}, \mathrm{Mn}, \mathrm{Na}, \mathrm{Rb}, \mathrm{Sb}, \mathrm{Sc}, \mathrm{Sm}, \mathrm{Sr}$, Th, and $\mathrm{Zn}$.

The soils were also characterized earlier with use of X-ray Fluorescence (Section 3.1.1.2). The results of the XRF determination are shown in the last line of Table A.1 for comparison. Three of the XRF values were also used in the determination of transfer factors because the INAA methods were insufficiently sensitive for $\mathrm{Br}, \mathrm{Cl}$, and $\mathrm{Ni}$. For that analysis, the uncertainty on each XRF measurement was assumed to be 10 percent.

Because of the number of elements reported, Table A.1 is divided into 8 parts. The following elements are reported alphabetically in each part:

Part 1: Al, As, Sb, Ba, Br

Part 2: $\mathrm{Ca}, \mathrm{Ce}, \mathrm{Cs}, \mathrm{Cl}, \mathrm{Cr}$

Part 3: Co, Eu, Hf, Fe, La

Part 4: Lu, Mg, Mn, Ni, Nd

Part 5: K, Ru, Sm, Sc, Na (from unashed samples)

Part 6: $\mathrm{Na}$ (from ashed samples), $\mathrm{Sr}, \mathrm{Ta}, \mathrm{Tb}, \mathrm{Th}$

Part 7: Ti, U (from 228 keV emission), U (from $277 \mathrm{keV}$ emission), $V$

Part 8: $\mathrm{Yb}, \mathrm{Zn}, \mathrm{Zr}$ 
Table A.1, Part 1. Concentrations of Elements in Botanical and Soil Samples (ppm)

\begin{tabular}{|c|c|c|c|c|c|c|c|c|c|c|c|}
\hline Sample Code & Crop/Fruit & Aluminum & $\pm 1 \sigma$ & Arsenic & $\pm 1 \sigma$ & Antimony & $\pm 1 \sigma$ & Barium & $\pm 1 \sigma$ & Bromine & $\pm 1 \sigma$ \\
\hline AF1 & Alfalfa & 42 & 15 & $<0.09$ & 0 & 0.042 & 0.002 & 6.83 & 0.66 & 15.16 & 1.91 \\
\hline AF2 & Alfalfa & 205 & 54 & 0.13 & 0.02 & 0.057 & 0.002 & 4.79 & 0.68 & 11.7 & 1.45 \\
\hline AF3 & Alfalfa & $<39$ & 10 & $<0.06$ & 0 & 0.09 & 0.003 & 4.91 & 0.63 & 8.85 & 1.2 \\
\hline AF4 & Alfalfa & $<38$ & 9 & $<0.08$ & 0 & 0.042 & 0.002 & 5.54 & 0.71 & 12.42 & 1.57 \\
\hline AF5 & Alfalfa & $<42$ & 10 & $<0.08$ & 0 & 0.006 & 0.001 & 4.92 & 0.66 & 17.83 & 2.06 \\
\hline ALL1 & Almond Tree 1 & 316 & 78 & 0.94 & 0.03 & 0.016 & 0.001 & 10.41 & 0.87 & 0.65 & 0.5 \\
\hline ALS1 & Almond Tree 1 & 110 & 28 & 1.16 & 0.02 & 0.141 & 0.004 & 3.51 & 0.49 & $<1.00$ & 0.1 \\
\hline ALF1 & Almond Tree 1 & 152 & 38 & 0.09 & 0.01 & 0.073 & 0.003 & 3.13 & 0.62 & 0.21 & 0.28 \\
\hline ALL2 & Almond Tree 2 & 603 & 150 & 0.75 & 0.04 & 0.029 & 0.002 & 13.04 & 1.15 & $<1.66$ & 0.17 \\
\hline ALS2 & Almond Tree 2 & 72 & 15 & 0.41 & 0.01 & 0.086 & 0.002 & 2.29 & 0.27 & $<0.70$ & 0.06 \\
\hline ALF2 & Almond Tree 2 & 332 & 67 & 0.12 & 0.01 & 0.074 & 0.002 & 4.96 & 0.67 & $<0.92$ & 0.08 \\
\hline ALF4 & Almond Tree 4 & 265 & 54 & 0.11 & 0.01 & 0.051 & 0.002 & 4.1 & 0.66 & $<0.89$ & 0.08 \\
\hline ALF5 & Almond Tree 5 & 232 & 47 & 0.11 & 0.01 & 0.04 & 0.002 & 3.53 & 0.53 & $<0.87$ & 0.08 \\
\hline ALF6 & Almond Tree 6 & 155 & 32 & 0.13 & 0.01 & 0.077 & 0.002 & 2.5 & 0.49 & $<0.86$ & 0.08 \\
\hline APL1 & Apple Tree 1 & 424 & 86 & 0.83 & 0.02 & 0.028 & 0.001 & 13.17 & 0.87 & $<1.64$ & 0.14 \\
\hline APS1 & Apple Tree 1 & 58 & 12 & 0.21 & 0.01 & 0.027 & 0.001 & 7.13 & 0.61 & $<0.90$ & 0.08 \\
\hline APF1 & Apple Tree 1 & 9 & 2 & 0.17 & 0.01 & 0.029 & 0.002 & $<0.8$ & 0.03 & $<0.49$ & 0.04 \\
\hline APL2 & Apple Tree 2 & 786 & 159 & 0.71 & 0.03 & 0.032 & 0.002 & 11.63 & 1.22 & 3.08 & 0.81 \\
\hline APS2 & Apple Tree 2 & 99 & 21 & 0.13 & 0.01 & 0.031 & 0.002 & 8.63 & 0.63 & $<0.87$ & 0.08 \\
\hline APF2 & Apple Tree 2 & 59 & 12 & 0.15 & 0.01 & 0.087 & 0.003 & $<0.92$ & 0.05 & $<0.53$ & 0.05 \\
\hline ARS4 & Apricot Tree 4 & 50 & 11 & 0.17 & 0.01 & 0.029 & 0.001 & 2.06 & 0.38 & $<0.81$ & 0.07 \\
\hline ARF4 & Apricot Tree 4 & 415 & 84 & 0.12 & 0.01 & 0.023 & 0.002 & 4.86 & 0.78 & $<0.76$ & 0.07 \\
\hline ARL5 & Apricot Tree 5 & 60 & 13 & 0.24 & 0.01 & 0.017 & 0.001 & 3.4 & 0.49 & $<0.92$ & 0.08 \\
\hline ARS5 & Apricot Tree 5 & 395 & 80 & 0.41 & 0.02 & 0.068 & 0.003 & 8.31 & 1.21 & $<1.72$ & 0.15 \\
\hline ARF5 & Apricot Composite & 81 & 17 & 0.09 & 0.01 & 0.024 & 0.002 & $<1.36$ & 0.06 & $<0.61$ & 0.05 \\
\hline CRL1 & Carob Tree 1 & 266 & 54 & 0.19 & 0.02 & 0.023 & 0.001 & 8.66 & 0.81 & 10.83 & 1.26 \\
\hline CRS1 & Carob Tree 1 & 132 & 27 & 0.09 & 0.01 & 0.072 & 0.003 & 4.4 & 0.62 & 0.94 & 0.25 \\
\hline CRF1a & Carob Tree 1 & 136 & 28 & $<0.03$ & 0 & 0.015 & 0.001 & 3.67 & 0.62 & $<0.98$ & 0.09 \\
\hline CRF1b & Carob Tree 1 & 95 & 20 & $<0.03$ & 0 & 0.014 & 0.001 & 2.5 & 0.55 & $<1.00$ & 0.09 \\
\hline CRL2 & Carob Tree 2 & 232 & 47 & 0.16 & 0.02 & 0.014 & 0.001 & 4.56 & 0.68 & 8.99 & 1 \\
\hline CRS2 & Carob Tree 2 & 100 & 21 & 0.07 & 0.01 & 0.12 & 0.004 & 2.19 & 0.43 & $<0.69$ & 0.06 \\
\hline CRF2a & Carob Tree 2 & 27 & 7 & $<0.02$ & 0 & 0.014 & 0.001 & $<1.57$ & 0.08 & 0.96 & 0.32 \\
\hline CRF2b & Carob Tree 2 & 31 & 7 & $<0.01$ & 0 & 0.012 & 0.001 & 1.33 & 0.39 & 0.78 & 0.31 \\
\hline FIL & Fig Tree 1 & 1095 & 220 & $<0.09$ & 0 & 0.035 & 0.003 & 18.65 & 1.85 & 7.55 & 1 \\
\hline FIS & Fig Tree 1 & 75 & 17 & 0.06 & 0.01 & 0.039 & 0.001 & 4.72 & 0.47 & 8.4 & 0.93 \\
\hline FIF & Fig Tree 1 & 84 & 18 & $<0.03$ & 0 & 0.09 & 0.003 & 2.16 & 0.5 & 7.38 & 0.86 \\
\hline FIL & Fig Tree 3 & 1250 & 252 & 0.24 & 0.03 & 0.05 & 0.003 & 20.38 & 1.84 & 3.86 & 0.86 \\
\hline FIS & Fig Tree 3 & 164 & 34 & 0.04 & 0.01 & 0.015 & 0.001 & 4.55 & 0.4 & 2.28 & 0.44 \\
\hline FIF & Fig Tree 3 & 54 & 12 & $<0.02$ & 0 & 0.038 & 0.002 & 1.18 & 0.4 & 4.02 & 0.55 \\
\hline FIF & Fig Tree 2 & 76 & 17 & $<0.03$ & 0 & 0.044 & 0.002 & 3.52 & 0.55 & 4.83 & 0.69 \\
\hline FIF & Fig Tree 4 & 31 & 8 & $<0.03$ & 0 & 0.109 & 0.004 & 2.29 & 0.7 & 6.74 & 0.74 \\
\hline FIF & Fig Tree 5 & 124 & 26 & $<0.03$ & 0 & 0.102 & 0.003 & 2.52 & 0.55 & 4.19 & 0.58 \\
\hline
\end{tabular}


Table A.1, Part 1. Concentrations of Elements in Botanical and Soil Samples (ppm)

\begin{tabular}{|c|c|c|c|c|c|c|c|c|c|c|c|}
\hline Sample Code & Crop/Fruit & Aluminum & $\pm 1 \sigma$ & Arsenic & $\pm 1 \sigma$ & Antimony & $\pm 1 \sigma$ & Barium & $\pm 1 \sigma$ & Bromine & $\pm 1 \sigma$ \\
\hline GRL1 & Grape Vine 1 & 465 & 94 & 0.63 & 0.02 & 0.038 & 0.002 & 9.69 & 1.15 & 6.45 & 1.08 \\
\hline GRS1 & Grape Vine 1 & 74 & 17 & 0.28 & 0.01 & 0.014 & 0.001 & 4 & 0.56 & 4.86 & 0.81 \\
\hline GRF1 & Grape Vine 1 & 73 & 19 & 0.57 & 0.03 & 0.153 & 0.005 & 3.55 & 0.84 & 18.96 & 1.95 \\
\hline GRL2 & Grape Vine 2 & 422 & 86 & 0.94 & 0.02 & 0.054 & 0.002 & 8.29 & 0.96 & 3.87 & 0.89 \\
\hline GRS2.3 & Grape Vine 2 & 69 & 21 & 0.52 & 0.04 & 0.046 & 0.002 & 2.29 & 0.61 & 19.97 & 2.07 \\
\hline GRS2.4 & Grape Vine 2 & 25 & 11 & 0.47 & 0.04 & 0.441 & 0.012 & $<2.46$ & 0.11 & 16.33 & 1.74 \\
\hline GRF2.2 & Grape Vine 2 & 31 & 7 & 0.13 & 0.01 & 0.035 & 0.002 & 1.78 & 0.48 & 1.93 & 0.44 \\
\hline GRF2.3 & Grape Vine 2 & 50 & 11 & 0.22 & 0.01 & 0.024 & 0.002 & $<1.39$ & 0.06 & 1.9 & 0.45 \\
\hline NCL1 & Nectarine Tree 1 & 430 & 87 & 0.34 & 0.01 & 0.026 & 0.001 & 8.5 & 1.08 & 3.41 & 0.71 \\
\hline NCS1 & Nectarine Tree 1 & 75 & 16 & 0.22 & 0.01 & 0.108 & 0.003 & 3.59 & 0.45 & $<1.23$ & 0.11 \\
\hline NCF1 & Nectarine Tree 1 & 64 & 13 & 0.02 & 0.003 & 0.107 & 0.003 & $<1.19$ & 0.05 & $<0.73$ & 0.06 \\
\hline NCL3 & Nectarine Tree 3 & 421 & 85 & 0.26 & 0.01 & 0.04 & 0.002 & 7.69 & 0.73 & $<1.80$ & 0.16 \\
\hline NCS3 & Nectarine Tree 3 & 48 & 10 & 0.11 & 0.004 & 0.069 & 0.002 & 2.03 & 0.31 & $<0.93$ & 0.08 \\
\hline FO1 & Feed Oats & 266 & 54 & $<0.08$ & 0 & 0.045 & 0.002 & 3.93 & 0.64 & 19.71 & 1.95 \\
\hline FO4 & Feed Oats & 267 & 55 & $<0.10$ & 0 & 0.025 & 0.002 & 3.98 & 0.78 & 24.01 & 2.29 \\
\hline FO6 & Feed Oats & 258 & 53 & $<0.09$ & 0 & 0.038 & 0.002 & 3.47 & 0.74 & 17.69 & 1.85 \\
\hline FO8 & Feed Oats & 241 & 50 & $<0.10$ & 0 & 0.022 & 0.002 & 3.71 & 0.84 & 26.27 & 2.49 \\
\hline PCL & Pecan & 211 & 44 & 0.1 & 0.01 & 0.015 & 0.001 & 3.75 & 0.59 & 14.61 & 1.58 \\
\hline PCS & Pecan & 66 & 15 & 0.37 & 0.01 & 0.602 & 0.014 & 1.92 & 0.38 & 1.53 & 0.36 \\
\hline PCF & Pecan & $<7$ & 1 & $<0.01$ & 0 & 0.039 & 0.002 & $<0.86$ & 0.04 & 0.83 & 0.31 \\
\hline GPL1 & Graft Pist. Tree 1 & 290 & 59 & 0.82 & 0.03 & 0.016 & 0.001 & 7.94 & 0.87 & 20.55 & 2 \\
\hline GPS1 & Graft Pist. Tree 1 & 59 & 12 & 0.07 & 0 & 0.255 & 0.007 & 4.31 & 0.54 & 0.52 & 0.36 \\
\hline GPF1 & Graft Pist. Tree 1 & 28 & 7 & 0.12 & 0.01 & 0.173 & 0.005 & $<1.24$ & 0.06 & 1.5 & 0.31 \\
\hline GPL2 & Graft Pist. Tree 2 & 250 & 51 & 0.66 & 0.03 & 0.062 & 0.003 & 8.01 & 0.91 & 23.03 & 2.23 \\
\hline GPS2 & Graft Pist. Tree 2 & 498 & 100 & 0.16 & 0.01 & 0.11 & 0.005 & 11.73 & 1.25 & 0.87 & 0.45 \\
\hline GPF2 & Graft Pist. Tree 2 & 28 & 6 & 0.11 & 0.01 & 0.097 & 0.004 & $<1.15$ & 0.06 & 1.71 & 0.3 \\
\hline GPL3 & Graft Pist. Tree 3 & 294 & 60 & 0.54 & 0.03 & 0.026 & 0.002 & 11.96 & 1.11 & 17.79 & 1.8 \\
\hline GPS3 & Graft Pist. Tree 3 & 219 & 44 & 0.07 & 0.004 & 0.025 & 0.002 & 4.79 & 0.54 & $<1.07$ & 0.09 \\
\hline GPF3 & Graft Pist. Tree 3 & 21 & 5 & 0.06 & 0.01 & 0.101 & 0.004 & $<1.25$ & 0.06 & 1.01 & 0.27 \\
\hline GPL4 & Graft Pist. Tree 4 & 517 & 104 & 0.73 & 0.03 & 0.052 & 0.003 & 20.41 & 1.51 & 7.8 & 1.08 \\
\hline GPS4 & Graft Pist. Tree 4 & 564 & 113 & 0.11 & 0.01 & 0.071 & 0.003 & 12.16 & 1.06 & $<1.45$ & 0.13 \\
\hline GPF4 & Graft Pist. Tree 4 & 38 & 8 & 0.1 & 0.01 & 0.166 & 0.005 & $<1.16$ & 0.06 & $<0.69$ & 0.06 \\
\hline NPL1 & Natural Pist. Tree 1 & 362 & 73 & 0.11 & 0.01 & 0.046 & 0.002 & $<1.23$ & 0.06 & 14.27 & 1.45 \\
\hline NPS1 & Natural Pist. Tree 1 & 420 & 85 & 0.12 & 0.01 & 0.021 & 0.002 & 11.59 & 1.12 & 1.36 & 0.43 \\
\hline NPF1 & Natural Pist. Tree 1 & 52 & 11 & 0.04 & 0 & 0.012 & 0.001 & $<0.39$ & 0.02 & 2.71 & 0.44 \\
\hline NPL2 & Natural Pist. Tree 2 & 387 & 78 & 0.62 & 0.02 & 0.024 & 0.002 & 10.18 & 1.11 & 8.74 & 1 \\
\hline NPS2 & Natural Pist. Tree 2 & 466 & 94 & 0.12 & 0.01 & 0.046 & 0.002 & 14.39 & 1.03 & 2.14 & 0.49 \\
\hline NPF2 & Natural Pist. Tree 2 & 99 & 18 & 0.23 & 0.01 & 0.05 & 0.002 & $<1.33$ & 0.07 & 3.97 & 0.5 \\
\hline NPL3 & Natural Pist. Tree 3 & 347 & 61 & 0.52 & 0.02 & 0.02 & 0.001 & 17.89 & 1.23 & 5.62 & 0.86 \\
\hline NPS3 & Natural Pist. Tree 3 & 321 & 56 & 0.13 & 0.01 & 0.052 & 0.003 & 16.58 & 1.35 & $<1.28$ & 0.1 \\
\hline NPF3 & Natural Pist. Tree 3 & 94 & 17 & 0.13 & 0.01 & 0.043 & 0.002 & $<1.54$ & 0.08 & 1.45 & 0.31 \\
\hline POL1 & Pomegranate Tree 1 & 265 & 47 & 0.3 & 0.03 & 0.04 & 0.002 & 8.38 & 0.91 & 48.74 & 3.76 \\
\hline
\end{tabular}


Table A.1, Part 1. Concentrations of Elements in Botanical and Soil Samples (ppm)

\begin{tabular}{|c|c|c|c|c|c|c|c|c|c|c|c|}
\hline Sample Code & Crop/Fruit & Aluminum & $\pm 1 \sigma$ & Arsenic & $\pm 1 \sigma$ & Antimony & $\pm 1 \sigma$ & Barium & $\pm 1 \sigma$ & Bromine & $\pm 1 \sigma$ \\
\hline POS1 & Pomegranate Tree 1 & 128 & 23 & 0.05 & 0.01 & 0.181 & 0.005 & 5.38 & 0.59 & 11.21 & 0.98 \\
\hline POF1 & Pomegranate Tree 1 & $<13$ & 2 & $<0.07$ & 0 & 0.06 & 0.004 & $<1.75$ & 0.09 & 18.67 & 1.49 \\
\hline POL4 & Pomegranate Tree 4 & 210 & 39 & 0.27 & 0.02 & 0.02 & 0.001 & 6.54 & 0.82 & 20.69 & 1.79 \\
\hline POS4 & Pomegranate Tree 4 & 103 & 20 & 0.05 & 0.01 & 0.066 & 0.003 & 5.71 & 0.59 & 3.94 & 0.54 \\
\hline POF4 & Pomegranate Tree 4 & $<15$ & 3 & $<0.05$ & 0 & 0.113 & 0.005 & $<1.79$ & 0.09 & 5.54 & 0.68 \\
\hline POL5 & Pomegranate Tree 5 & 176 & 33 & 0.31 & 0.02 & 0.015 & 0.001 & 6.49 & 0.76 & 17 & 1.52 \\
\hline POS5 & Pomegranate Tree 5 & 66 & 13 & 0.05 & 0.01 & 0.086 & 0.003 & 4.72 & 0.62 & 5.72 & 0.7 \\
\hline POF5 & Pomegranate Tree 5 & $<15$ & 3 & $<0.03$ & 0 & 0.085 & 0.003 & $<1.4$ & 0.07 & 6.44 & 0.68 \\
\hline NYE & County Soil 1 & 69024 & 491 & 4.57 & 0.46 & 0.605 & 0.048 & 760.82 & 49.33 & $<21.05$ & 1.23 \\
\hline NYE & County Soil 2 & 68071 & 480 & 4.94 & 0.48 & 0.725 & 0.056 & 727.76 & 50.49 & $<21.03$ & 1.23 \\
\hline NYE & County Soil 3 & 66689 & 483 & 4.95 & 0.46 & 0.6 & 0.057 & 714.95 & 48.77 & $<20.07$ & 1.17 \\
\hline Soil XRF & & 71000 & & & & & & 694 & & 54000 & \\
\hline
\end{tabular}


Table A.1, Part 2. Concentrations of Elements in Botanical and Soil Samples (ppm)

\begin{tabular}{|c|c|c|c|c|c|c|c|c|c|c|c|}
\hline Sample Code & Crop/Fruit & Calcium & $\pm 1 \sigma$ & Cerium & $\pm 1 \sigma$ & Cesium & $\pm 1 \sigma$ & Chlorine & $\pm 1 \sigma$ & Chromium & $\pm 1 \sigma$ \\
\hline AF1 & Alfalfa & 15070 & 688 & 0.13 & 0.01 & 0.013 & 0.001 & 5812 & 235 & 0.08 & 0.02 \\
\hline AF2 & Alfalfa & 14355 & 635 & 0.37 & 0.02 & 0.03 & 0.002 & 3978 & 159 & 0.23 & 0.02 \\
\hline AF3 & Alfalfa & 15426 & 681 & 0.09 & 0.01 & 0.011 & 0.001 & 4777 & 191 & 0.17 & 0.02 \\
\hline AF4 & Alfalfa & 15756 & 694 & 0.13 & 0.02 & 0.016 & 0.001 & 4149 & 166 & 0.1 & 0.02 \\
\hline AF5 & Alfalfa & 15508 & 685 & 0.13 & 0.01 & 0.015 & 0.001 & 5172 & 207 & 0.2 & 0.02 \\
\hline ALL1 & Almond Tree 1 & 53327 & 2303 & 0.42 & 0.02 & 0.044 & 0.002 & 97 & 7 & 0.48 & 0.02 \\
\hline ALS1 & Almond Tree 1 & 32702 & 1424 & 0.2 & 0.01 & 0.018 & 0.001 & 37 & 4 & 0.17 & 0.01 \\
\hline ALF1 & Almond Tree 1 & 2347 & 142 & 0.26 & 0.02 & 0.022 & 0.002 & 137 & 7 & 0.23 & 0.02 \\
\hline ALL2 & Almond Tree 2 & 44392 & 1898 & 1.23 & 0.02 & 0.104 & 0.003 & 308 & 14 & 1.25 & 0.03 \\
\hline ALS2 & Almond Tree 2 & 12470 & 472 & 0.11 & 0.01 & 0.012 & 0.001 & 109 & 5 & 0.22 & 0.01 \\
\hline ALF2 & Almond Tree 2 & 3673 & 168 & 0.57 & 0.02 & 0.039 & 0.002 & 144 & 7 & 0.63 & 0.02 \\
\hline ALF4 & Almond Tree 4 & 2950 & 133 & 0.42 & 0.02 & 0.033 & 0.002 & 169 & 7 & 0.35 & 0.02 \\
\hline ALF5 & Almond Tree 5 & 3932 & 173 & 0.35 & 0.01 & 0.032 & 0.001 & 141 & 6 & 0.47 & 0.02 \\
\hline ALF6 & Almond Tree 6 & 3215 & 151 & 0.25 & 0.01 & 0.024 & 0.001 & 142 & 7 & 0.55 & 0.02 \\
\hline APL1 & Apple Tree 1 & 29577 & 1067 & 0.66 & 0.02 & 0.061 & 0.002 & 197 & 10 & 0.85 & 0.03 \\
\hline APS1 & Apple Tree 1 & 28344 & 1025 & 0.12 & 0.01 & 0.011 & 0.001 & 57 & 5 & 0.14 & 0.01 \\
\hline APF1 & Apple Tree 1 & 425 & 34 & 0.13 & 0.01 & 0.007 & 0.001 & 10 & 1 & 0.12 & 0.01 \\
\hline APL2 & Apple Tree 2 & 12669 & 488 & 1.17 & 0.03 & 0.089 & 0.004 & 526 & 19 & 2.2 & 0.05 \\
\hline APS2 & Apple Tree 2 & 20462 & 750 & 0.09 & 0.01 & 0.011 & 0.001 & 42 & 4 & 0.18 & 0.01 \\
\hline APF2 & Apple Tree 2 & 488 & 40 & 0.08 & 0.01 & 0.012 & 0.001 & 47 & 3 & 0.23 & 0.02 \\
\hline ARS4 & Apricot Tree 4 & 12905 & 488 & 0.1 & 0.01 & 0.01 & 0.001 & 92 & 5 & 0.11 & 0.01 \\
\hline ARF4 & Apricot Tree 4 & 1623 & 87 & 0.65 & 0.03 & 0.038 & 0.003 & 54 & 4 & 0.32 & 0.03 \\
\hline ARL5 & Apricot Tree 5 & 18980 & 700 & 0.12 & 0.02 & 0.011 & 0.001 & 58 & 4 & 0.14 & 0.02 \\
\hline ARS5 & Apricot Tree 5 & 27817 & 1004 & 0.6 & 0.03 & 0.061 & 0.003 & 226 & 10 & 0.7 & 0.03 \\
\hline ARF5 & Apricot Composite & 864 & 61 & 0.13 & 0.02 & 0.014 & 0.002 & 54 & 3 & 0.14 & 0.02 \\
\hline CRL1 & Carob Tree 1 & 26178 & 945 & 0.38 & 0.02 & 0.041 & 0.002 & 847 & 30 & 0.73 & 0.03 \\
\hline CRS1 & Carob Tree 1 & 16455 & 613 & 0.25 & 0.01 & 0.019 & 0.001 & 287 & 11 & 0.22 & 0.02 \\
\hline CRF1a & Carob Tree 1 & 9185 & 362 & 0.19 & 0.02 & 0.017 & 0.001 & 551 & 19 & 0.46 & 0.02 \\
\hline CRF1b & Carob Tree 1 & 7797 & 307 & 0.09 & 0.02 & 0.013 & 0.001 & 413 & 15 & 0.43 & 0.03 \\
\hline CRL2 & Carob Tree 2 & 14899 & 553 & 0.34 & 0.02 & 0.033 & 0.002 & 1123 & 38 & 0.67 & 0.02 \\
\hline CRS2 & Carob Tree 2 & 8726 & 344 & 0.16 & 0.01 & 0.014 & 0.001 & 176 & 7 & 0.22 & 0.02 \\
\hline CRF2a & Carob Tree 2 & 5900 & 243 & $<0.06$ & 0 & 0.007 & 0.002 & 575 & 20 & 0.24 & 0.02 \\
\hline CRF2b & Carob Tree 2 & 4804 & 202 & 0.04 & 0.01 & 0.006 & 0.001 & 577 & 20 & 0.14 & 0.01 \\
\hline FIL & Fig Tree 1 & 29387 & 1051 & 1.66 & 0.03 & 0.104 & 0.004 & 1793 & 60 & 1.04 & 0.04 \\
\hline FIS & Fig Tree 1 & 17400 & 637 & 0.12 & 0.01 & 0.01 & 0.001 & 2096 & 70 & 0.13 & 0.01 \\
\hline FIF & Fig Tree 1 & 13704 & 510 & 0.08 & 0.01 & 0.011 & 0.001 & 1770 & 59 & 0.16 & 0.02 \\
\hline FIL & Fig Tree 3 & 26505 & 952 & 2.34 & 0.04 & 0.153 & 0.005 & 1442 & 49 & 1.46 & 0.05 \\
\hline FIS & Fig Tree 3 & 21400 & 777 & 0.18 & 0.01 & 0.012 & 0.001 & 689 & 24 & 0.2 & 0.01 \\
\hline FIF & Fig Tree 3 & 5891 & 235 & 0.03 & 0.01 & 0.007 & 0.001 & 1267 & 43 & 0.19 & 0.02 \\
\hline FIF & Fig Tree 2 & 12683 & 473 & $<0.03$ & 0 & 0.014 & 0.001 & 1932 & 64 & 0.11 & 0.01 \\
\hline FIF & Fig Tree 4 & 8010 & 314 & $<0.05$ & 0 & 0.007 & 0.002 & 1597 & 54 & 0.16 & 0.02 \\
\hline FIF & Fig Tree 5 & 8503 & 330 & 0.1 & 0.02 & 0.012 & 0.002 & 1388 & 47 & 0.19 & 0.02 \\
\hline
\end{tabular}


Table A.1, Part 2. Concentrations of Elements in Botanical and Soil Samples (ppm)

\begin{tabular}{|c|c|c|c|c|c|c|c|c|c|c|c|}
\hline Sample Code & Crop/Fruit & Calcium & $\pm 1 \sigma$ & Cerium & $\pm 1 \sigma$ & Cesium & $\pm 1 \sigma$ & Chlorine & $\pm 1 \sigma$ & Chromium & $\pm 1 \sigma$ \\
\hline GRL1 & Grape Vine 1 & 32953 & 1174 & 0.55 & 0.03 & 0.057 & 0.002 & 998 & 34 & 0.27 & 0.03 \\
\hline GRS1 & Grape Vine 1 & 12527 & 480 & 0.13 & 0.01 & 0.016 & 0.001 & 1533 & 52 & 0.41 & 0.02 \\
\hline GRF1 & Grape Vine 1 & 11358 & 443 & 0.08 & 0.02 & 0.016 & 0.001 & 3738 & 124 & 0.23 & 0.02 \\
\hline GRL2 & Grape Vine 2 & 31368 & 1126 & 0.48 & 0.02 & 0.043 & 0.002 & 914 & 32 & 0.52 & 0.03 \\
\hline GRS2.3 & Grape Vine 2 & 10102 & 410 & 0.07 & 0.01 & 0.009 & 0.001 & 3698 & 123 & 0.16 & 0.02 \\
\hline GRS2.4 & Grape Vine 2 & 9856 & 393 & $<0.06$ & 0 & 0.01 & 0.002 & 3711 & 123 & 0.23 & 0.03 \\
\hline GRF2.2 & Grape Vine 2 & 5473 & 225 & $<0.04$ & 0 & 0.01 & 0.001 & 350 & 13 & 0.11 & 0.02 \\
\hline GRF2.3 & Grape Vine 2 & 5379 & 221 & $<0.05$ & 0 & 0.013 & 0.001 & 372 & 14 & 0.24 & 0.02 \\
\hline NCL1 & Nectarine Tree 1 & 19284 & 703 & 0.63 & 0.02 & 0.068 & 0.003 & 719 & 25 & 0.9 & 0.03 \\
\hline NCS1 & Nectarine Tree 1 & 32240 & 1152 & 0.18 & 0.01 & 0.009 & 0.001 & 83 & 6 & 0.21 & 0.01 \\
\hline NCF1 & Nectarine Tree 1 & 1505 & 83 & 0.13 & 0.01 & 0.013 & 0.002 & 53 & 3 & 0.12 & 0.02 \\
\hline NCL3 & Nectarine Tree 3 & 14822 & 551 & 0.6 & 0.02 & 0.064 & 0.002 & 334 & 13 & 1.1 & 0.03 \\
\hline NCS3 & Nectarine Tree 3 & 14159 & 536 & 0.09 & 0.01 & 0.009 & 0.001 & 41 & 4 & 0.13 & 0.01 \\
\hline FO1 & Feed Oats & 4349 & 192 & 0.12 & 0.02 & 0.011 & 0.001 & 2609 & 87 & 0.34 & 0.02 \\
\hline FO4 & Feed Oats & 2601 & 139 & 0.25 & 0.02 & 0.02 & 0.002 & 3025 & 101 & 0.42 & 0.03 \\
\hline FO6 & Feed Oats & 2949 & 156 & 0.13 & 0.02 & 0.013 & 0.002 & 2475 & 83 & 0.47 & 0.03 \\
\hline FO8 & Feed Oats & 3441 & 160 & 0.11 & 0.02 & 0.017 & 0.002 & 3137 & 105 & 0.33 & 0.03 \\
\hline PCL & Pecan & 22568 & 827 & 0.35 & 0.01 & 0.036 & 0.002 & 5144 & 171 & 0.42 & 0.02 \\
\hline PCS & Pecan & 15503 & 589 & 0.14 & 0.01 & 0.013 & 0.001 & 772 & 27 & 0.26 & 0.01 \\
\hline PCF & Pecan & 1297 & 81 & $<0.03$ & 0 & $<0.002$ & 0 & 610 & 21 & 0.05 & 0.01 \\
\hline GPL1 & Graft Pist. Tree 1 & 24734 & 902 & 0.46 & 0.02 & 0.054 & 0.002 & 3553 & 118 & 0.63 & 0.03 \\
\hline GPS1 & Graft Pist. Tree 1 & 10796 & 422 & 0.12 & 0.01 & 0.011 & 0.001 & 197 & 8 & 0.65 & 0.02 \\
\hline GPF1 & Graft Pist. Tree 1 & 816 & 64 & $<0.04$ & 0 & 0.009 & 0.001 & 331 & 12 & 0.17 & 0.02 \\
\hline GPL2 & Graft Pist. Tree 2 & 27226 & 988 & 0.42 & 0.02 & 0.038 & 0.002 & 4012 & 133 & 0.76 & 0.03 \\
\hline GPS2 & Graft Pist. Tree 2 & 22377 & 824 & 1.37 & 0.02 & 0.089 & 0.004 & 97 & 7 & 0.8 & 0.04 \\
\hline GPF2 & Graft Pist. Tree 2 & 1062 & 71 & 0.06 & 0.02 & 0.008 & 0.001 & 340 & 12 & 0.16 & 0.02 \\
\hline GPL3 & Graft Pist. Tree 3 & 34174 & 1228 & 0.5 & 0.02 & 0.049 & 0.002 & 4082 & 136 & 1.22 & 0.04 \\
\hline GPS3 & Graft Pist. Tree 3 & 16663 & 629 & 0.3 & 0.01 & 0.026 & 0.001 & 172 & 8 & 0.23 & 0.02 \\
\hline GPF3 & Graft Pist. Tree 3 & 1216 & 76 & $<0.05$ & 0 & 0.007 & 0.001 & 402 & 14 & 0.08 & 0.02 \\
\hline GPL4 & Graft Pist. Tree 4 & 23789 & 871 & 0.9 & 0.02 & 0.08 & 0.003 & 1909 & 64 & 0.93 & 0.03 \\
\hline GPS4 & Graft Pist. Tree 4 & 22268 & 822 & 0.67 & 0.02 & 0.05 & 0.002 & 93 & 6 & 0.46 & 0.02 \\
\hline GPF4 & Graft Pist. Tree 4 & 1026 & 74 & 0.08 & 0.01 & 0.01 & 0.001 & 226 & 9 & 0.12 & 0.02 \\
\hline NPL1 & Natural Pist. Tree 1 & 12701 & 489 & 0.08 & 0.01 & 0.015 & 0.001 & 1702 & 57 & 0.2 & 0.02 \\
\hline NPS1 & Natural Pist. Tree 1 & 21191 & 784 & 0.75 & 0.02 & 0.045 & 0.003 & 301 & 12 & 0.35 & 0.03 \\
\hline NPF1 & Natural Pist. Tree 1 & 1854 & 105 & 0.03 & 0 & 0.004 & 0 & 752 & 26 & 0.05 & 0.01 \\
\hline NPL2 & Natural Pist. Tree 2 & 15350 & 574 & 0.72 & 0.02 & 0.075 & 0.003 & 1265 & 43 & 0.45 & 0.03 \\
\hline NPS2 & Natural Pist. Tree 2 & 22547 & 832 & 0.71 & 0.02 & 0.046 & 0.002 & 167 & 7 & 0.32 & 0.02 \\
\hline NPF2 & Natural Pist. Tree 2 & 3220 & 142 & 0.12 & 0.02 & 0.014 & 0.001 & 883 & 26 & 0.11 & 0.02 \\
\hline NPL3 & Natural Pist. Tree 3 & 24812 & 797 & 0.55 & 0.02 & 0.054 & 0.002 & 886 & 27 & 0.44 & 0.02 \\
\hline NPS3 & Natural Pist. Tree 3 & 29025 & 929 & 0.8 & 0.02 & 0.053 & 0.003 & 138 & 7 & 0.41 & 0.03 \\
\hline NPF3 & Natural Pist. Tree 3 & 2876 & 127 & 0.1 & 0.02 & 0.014 & 0.001 & 503 & 16 & 0.12 & 0.02 \\
\hline POL1 & Pomegranate Tree 1 & 32672 & 1033 & 0.46 & 0.02 & 0.049 & 0.002 & 3487 & 100 & 0.56 & 0.03 \\
\hline
\end{tabular}


Table A.1, Part 2. Concentrations of Elements in Botanical and Soil Samples (ppm)

\begin{tabular}{|c|c|c|c|c|c|c|c|c|c|c|c|}
\hline Sample Code & Crop/Fruit & Calcium & $\mathbf{\pm 1 \sigma}$ & Cerium & $\mathbf{\pm 1 \sigma}$ & Cesium & $\mathbf{\pm 1 \sigma}$ & Chlorine & $\mathbf{\pm 1 \sigma}$ & Chromium & $\mathbf{\pm 1 \sigma}$ \\
\hline POS1 & Pomegranate Tree 1 & 18007 & 595 & 0.31 & 0.01 & 0.022 & 0.001 & 1295 & 38 & 0.46 & 0.02 \\
\hline POF1 & Pomegranate Tree 1 & 3857 & 158 & $<0.06$ & 0 & 0.007 & 0.001 & 2579 & 74 & 0.07 & 0.02 \\
\hline POL4 & Pomegranate Tree 4 & 22618 & 728 & 0.33 & 0.02 & 0.041 & 0.002 & 5966 & 171 & 0.41 & 0.02 \\
\hline POS4 & Pomegranate Tree 4 & 16907 & 560 & 0.2 & 0.02 & 0.018 & 0.001 & 1941 & 56 & 0.33 & 0.02 \\
\hline POF4 & Pomegranate Tree 4 & 2056 & 108 & $<0.06$ & 0 & $<0.004$ & 0 & 3132 & 90 & 0.15 & 0.03 \\
\hline POL5 & Pomegranate Tree 5 & 21341 & 690 & 0.34 & 0.02 & 0.037 & 0.002 & 5347 & 153 & 0.5 & 0.02 \\
\hline POS5 & Pomegranate Tree 5 & 17283 & 568 & 0.13 & 0.01 & 0.012 & 0.001 & 2117 & 61 & 0.22 & 0.02 \\
\hline POF5 & Pomegranate Tree 5 & 2419 & 110 & $<0.05$ & 0 & $<0.003$ & 0 & 3169 & 91 & 0.2 & 0.02 \\
\hline NYE & County Soil 1 & 30345 & 2258 & 97.69 & 0.89 & 5.793 & 0.152 & $<240$ & 15 & 14.99 & 0.8 \\
\hline NYE & County Soil 2 & 30901 & 2261 & 92.99 & 0.86 & 5.638 & 0.153 & $<246$ & 15 & 15.71 & 0.85 \\
\hline NYE & County Soil 3 & 31042 & 2414 & 86.74 & 0.82 & 5.542 & 0.148 & $<244$ & 15 & 16.72 & 0.89 \\
\hline Soil XRF & & & & 95 & & & & 9300 & & 13 & \\
\hline
\end{tabular}


Table A.1, Part 3. Concentrations of Elements in Botanical and Soil Samples (ppm)

\begin{tabular}{|c|c|c|c|c|c|c|c|c|c|c|c|}
\hline Sample Code & Crop/Fruit & Cobalt & $\pm 1 \sigma$ & Europium & $\pm 1 \sigma$ & Hafnium & $\pm 1 \sigma$ & Iron & $\pm 1 \sigma$ & Lawrencium & $\pm 1 \sigma$ \\
\hline $\mathrm{AF} 1$ & Alfalfa & 0.1 & 0 & $<0.001$ & 0 & 0.008 & 0.001 & 55 & 1 & 0.067 & 0.002 \\
\hline AF2 & Alfalfa & 0.12 & 0 & 0.003 & 0 & 0.023 & 0.001 & 106 & 2 & 0.189 & 0.003 \\
\hline AF3 & Alfalfa & 0.1 & 0 & 0.001 & 0 & 0.004 & 0.001 & 55 & 1 & 0.049 & 0.002 \\
\hline AF4 & Alfalfa & 0.09 & 0 & 0.001 & 0 & 0.003 & 0.001 & 61 & 1 & 0.059 & 0.002 \\
\hline AF5 & Alfalfa & 0.11 & 0 & 0.001 & 0 & 0.006 & 0.001 & 62 & 1 & 0.063 & 0.002 \\
\hline ALL1 & Almond Tree 1 & 0.05 & 0 & 0.005 & 0 & 0.029 & 0.002 & 155 & 2 & 0.207 & 0.004 \\
\hline ALS1 & Almond Tree 1 & 0.02 & 0 & 0.002 & 0 & 0.015 & 0.001 & 64 & 1 & 0.105 & 0.002 \\
\hline ALF1 & Almond Tree 1 & 0.03 & 0 & 0.004 & 0 & 0.027 & 0.002 & 74 & 2 & 0.134 & 0.003 \\
\hline ALL2 & Almond Tree 2 & 0.13 & 0 & 0.012 & 0 & 0.101 & 0.003 & 363 & 5 & 0.611 & 0.007 \\
\hline ALS2 & Almond Tree 2 & 0.02 & 0 & 0.001 & 0 & 0.008 & 0.001 & 42 & 1 & 0.054 & 0.001 \\
\hline ALF2 & Almond Tree 2 & 0.05 & 0 & 0.006 & 0 & 0.061 & 0.002 & 148 & 2 & 0.305 & 0.003 \\
\hline ALF4 & Almond Tree 4 & 0.04 & 0 & 0.005 & 0 & 0.046 & 0.002 & 119 & 2 & 0.206 & 0.003 \\
\hline ALF5 & Almond Tree 5 & 0.03 & 0 & 0.004 & 0 & 0.039 & 0.002 & 95 & 2 & 0.17 & 0.002 \\
\hline ALF6 & Almond Tree 6 & 0.03 & 0 & 0.004 & 0 & 0.025 & 0.002 & 79 & 1 & 0.125 & 0.002 \\
\hline APL1 & Apple Tree 1 & 0.09 & 0 & 0.007 & 0 & 0.05 & 0.002 & 234 & 3 & 0.327 & 0.003 \\
\hline APS1 & Apple Tree 1 & 0.03 & 0 & 0.002 & 0 & 0.009 & 0.001 & 41 & 1 & 0.059 & 0.001 \\
\hline APF1 & Apple Tree 1 & 0.01 & 0 & $<0.001$ & 0 & $<0.002$ & 0 & 7 & 1 & 0.053 & 0.001 \\
\hline APL2 & Apple Tree 2 & 0.13 & 0 & 0.012 & 0.001 & 0.085 & 0.003 & 323 & 5 & 0.582 & 0.006 \\
\hline APS2 & Apple Tree 2 & 0.02 & 0 & 0.001 & 0 & 0.008 & 0.001 & 41 & 1 & 0.049 & 0.001 \\
\hline APF2 & Apple Tree 2 & 0.01 & 0 & 0.002 & 0 & 0.007 & 0.001 & 23 & 1 & 0.036 & 0.001 \\
\hline ARS4 & Apricot Tree 4 & 0.01 & 0 & 0.001 & 0 & 0.006 & 0.001 & 34 & 1 & 0.045 & 0.001 \\
\hline ARF4 & Apricot Tree 4 & 0.04 & 0 & 0.007 & 0 & 0.063 & 0.003 & 120 & 2 & 0.327 & 0.004 \\
\hline ARL5 & Apricot Tree 5 & 0.02 & 0 & 0.001 & 0 & 0.007 & 0.001 & 41 & 1 & 0.054 & 0.001 \\
\hline ARS5 & Apricot Tree 5 & 0.07 & 0 & 0.006 & 0.001 & 0.029 & 0.002 & 195 & 3 & 0.264 & 0.004 \\
\hline ARF5 & Apricot Composite & 0.03 & 0 & 0.002 & 0 & 0.011 & 0.002 & 43 & 1 & 0.054 & 0.002 \\
\hline CRL1 & Carob Tree 1 & 0.06 & 0 & 0.005 & 0 & 0.027 & 0.002 & 167 & 3 & 0.184 & 0.003 \\
\hline CRS1 & Carob Tree 1 & 0.03 & 0 & 0.003 & 0 & 0.019 & 0.001 & 78 & 2 & 0.13 & 0.002 \\
\hline CRF1a & Carob Tree 1 & 0.04 & 0 & 0.002 & 0 & 0.016 & 0.001 & 71 & 1 & 0.077 & 0.002 \\
\hline CRF1b & Carob Tree 1 & 0.03 & 0 & 0.002 & 0 & 0.011 & 0.001 & 57 & 1 & 0.062 & 0.001 \\
\hline CRL2 & Carob Tree 2 & 0.05 & 0 & 0.004 & 0 & 0.025 & 0.001 & 126 & 2 & 0.152 & 0.002 \\
\hline CRS2 & Carob Tree 2 & 0.03 & 0 & $<0.001$ & 0 & 0.009 & 0.001 & 52 & 1 & 0.075 & 0.001 \\
\hline CRF2a & Carob Tree 2 & 0.02 & 0 & 0.001 & 0 & $<0.003$ & 0 & 28 & 1 & 0.014 & 0.001 \\
\hline CRF2b & Carob Tree 2 & 0.02 & 0 & 0.001 & 0 & 0.003 & 0.001 & 25 & 1 & 0.02 & 0.001 \\
\hline FIL & Fig Tree 1 & 0.14 & 0 & 0.019 & 0.001 & 0.136 & 0.005 & 439 & 6 & 0.873 & 0.009 \\
\hline FIS & Fig Tree 1 & 0.04 & 0 & 0.001 & 0 & 0.009 & 0.001 & 45 & 1 & 0.064 & 0.001 \\
\hline FIF & Fig Tree 1 & 0.04 & 0 & 0.001 & 0 & 0.012 & 0.001 & 47 & 1 & 0.043 & 0.001 \\
\hline FIL & Fig Tree 3 & 0.2 & 0 & 0.026 & 0.001 & 0.217 & 0.007 & 590 & 8 & 1.221 & 0.011 \\
\hline FIS & Fig Tree 3 & 0.03 & 0 & 0.002 & 0 & 0.012 & 0.001 & 48 & 1 & 0.086 & 0.001 \\
\hline FIF & Fig Tree 3 & 0.02 & 0 & 0 & 0 & 0.006 & 0.001 & 33 & 1 & 0.021 & 0.001 \\
\hline FIF & Fig Tree 2 & 0.03 & 0 & 0.001 & 0 & 0.005 & 0.001 & 40 & 1 & 0.029 & 0.001 \\
\hline FIF & Fig Tree 4 & 0.02 & 0 & $<0.001$ & 0 & $<0.003$ & 0 & 41 & 1 & 0.02 & 0.002 \\
\hline FIF & Fig Tree 5 & 0.03 & 0 & 0.002 & 0 & 0.011 & 0.001 & 47 & 1 & 0.051 & 0.002 \\
\hline GRL1 & Grape Vine 1 & 0.08 & 0 & 0.006 & 0 & 0.036 & 0.002 & 201 & 3 & 0.277 & 0.004 \\
\hline
\end{tabular}


Table A.1, Part 3. Concentrations of Elements in Botanical and Soil Samples (ppm)

\begin{tabular}{|c|c|c|c|c|c|c|c|c|c|c|c|}
\hline Sample Code & Crop/Fruit & Cobalt & $\pm 1 \sigma$ & Europium & $\pm 1 \sigma$ & Hafnium & $\pm 1 \sigma$ & Iron & $\pm 1 \sigma$ & Lawrencium & $\pm 1 \sigma$ \\
\hline GRS1 & Grape Vine 1 & 0.05 & 0 & 0.002 & 0 & 0.011 & 0.001 & 49 & 1 & 0.072 & 0.002 \\
\hline GRF1 & Grape Vine 1 & 0.04 & 0 & $<0.001$ & 0 & 0.011 & 0.001 & 47 & 1 & 0.06 & 0.004 \\
\hline GRL2 & Grape Vine 2 & 0.09 & 0 & 0.006 & 0 & 0.035 & 0.002 & 197 & 3 & 0.264 & 0.003 \\
\hline GRS2.3 & Grape Vine 2 & 0.06 & 0 & $<0.001$ & 0 & 0.003 & 0.001 & 23 & 1 & $<0.009$ & 0 \\
\hline GRS2.4 & Grape Vine 2 & 0.07 & 0 & $<0.002$ & 0 & $<0.005$ & 0 & 26 & 2 & $<0.015$ & 0 \\
\hline GRF2.2 & Grape Vine 2 & 0.02 & 0 & 0 & 0 & $<0.002$ & 0 & 28 & 1 & 0.021 & 0.001 \\
\hline GRF2.3 & Grape Vine 2 & 0.02 & 0 & $<0.001$ & 0 & 0.005 & 0.001 & 39 & 1 & 0.029 & 0.001 \\
\hline $\mathrm{NCL} 1$ & Nectarine Tree 1 & 0.08 & 0 & 0.007 & 0 & 0.037 & 0.002 & 220 & 3 & 0.317 & 0.003 \\
\hline NCS1 & Nectarine Tree 1 & 0.02 & 0 & 0.002 & 0 & 0.007 & 0.001 & 44 & 1 & 0.082 & 0.001 \\
\hline NCF1 & Nectarine Tree 1 & 0.02 & 0 & 0.001 & 0 & 0.008 & 0.001 & 36 & 1 & 0.075 & 0.001 \\
\hline NCL3 & Nectarine Tree 3 & 0.08 & 0 & 0.006 & 0 & 0.038 & 0.002 & 219 & 3 & 0.303 & 0.003 \\
\hline NCS3 & Nectarine Tree 3 & 0.01 & 0 & 0.001 & 0 & 0.004 & 0.001 & 34 & 1 & 0.045 & 0.001 \\
\hline FO1 & Feed Oats & 0.06 & 0 & 0.002 & 0 & 0.009 & 0.001 & 51 & 1 & 0.062 & 0.002 \\
\hline FO4 & Feed Oats & 0.08 & 0 & 0.002 & 0 & 0.025 & 0.002 & 82 & 2 & 0.12 & 0.003 \\
\hline FO6 & Feed Oats & 0.11 & 0 & 0.002 & 0 & 0.018 & 0.002 & 62 & 2 & 0.082 & 0.003 \\
\hline FO8 & Feed Oats & 0.09 & 0 & $<0.001$ & 0 & 0.006 & 0.001 & 43 & 2 & 0.042 & 0.003 \\
\hline $\mathrm{PCL}$ & Pecan & 0.04 & 0 & 0.004 & 0 & 0.022 & 0.001 & 136 & 2 & 0.165 & 0.002 \\
\hline PCS & Pecan & 0.02 & 0 & $<0.001$ & 0 & 0.009 & 0.001 & 50 & 1 & 0.065 & 0.001 \\
\hline PCF & Pecan & 0.01 & 0 & 0 & 0 & $<0.002$ & 0 & 16 & 1 & 0.01 & 0.001 \\
\hline GPL1 & Graft Pist. Tree 1 & 0.05 & 0 & 0.005 & 0 & 0.027 & 0.002 & 158 & 3 & 0.217 & 0.003 \\
\hline GPS1 & Graft Pist. Tree 1 & 0.01 & 0 & 0.002 & 0 & 0.007 & 0.001 & 46 & 1 & 0.057 & 0.001 \\
\hline GPF1 & Graft Pist. Tree 1 & 0.02 & 0 & 0.002 & 0 & 0.005 & 0.001 & 32 & 1 & 0.018 & 0.001 \\
\hline GPL2 & Graft Pist. Tree 2 & 0.05 & 0 & 0.004 & 0 & 0.028 & 0.002 & 147 & 2 & 0.197 & 0.003 \\
\hline GPS2 & Graft Pist. Tree 2 & 0.11 & 0 & 0.013 & 0.001 & 0.106 & 0.004 & 334 & 5 & 0.652 & 0.007 \\
\hline GPF2 & Graft Pist. Tree 2 & 0.01 & 0 & $<0.001$ & 0 & $<0.003$ & 0 & 29 & 1 & 0.018 & 0.001 \\
\hline GPL3 & Graft Pist. Tree 3 & 0.06 & 0 & 0.005 & 0 & 0.031 & 0.002 & 169 & 3 & 0.221 & 0.003 \\
\hline GPS3 & Graft Pist. Tree 3 & 0.03 & 0 & 0.002 & 0 & 0.017 & 0.001 & 84 & 2 & 0.137 & 0.002 \\
\hline GPF3 & Graft Pist. Tree 3 & 0.01 & 0 & 0.001 & 0 & $<0.003$ & 0 & 34 & 1 & 0.012 & 0.001 \\
\hline GPL4 & Graft Pist. Tree 4 & 0.08 & 0 & 0.008 & 0 & 0.059 & 0.003 & 240 & 4 & 0.436 & 0.005 \\
\hline GPS4 & Graft Pist. Tree 4 & 0.06 & 0 & 0.007 & 0 & 0.044 & 0.002 & 164 & 3 & 0.317 & 0.003 \\
\hline GPF4 & Graft Pist. Tree 4 & 0.01 & 0 & 0.001 & 0 & $<0.003$ & 0 & 29 & 1 & 0.027 & 0.001 \\
\hline NPL1 & Natural Pist. Tree 1 & 0.02 & 0 & 0.01 & 0 & 0.005 & 0.001 & 43 & 1 & 0.038 & 0.001 \\
\hline NPS1 & Natural Pist. Tree 1 & 0.06 & 0 & 0.008 & 0.001 & 0.036 & 0.002 & 161 & 3 & 0.336 & 0.005 \\
\hline NPF1 & Natural Pist. Tree 1 & 0.01 & 0 & 0.003 & 0 & $<0.001$ & 0 & 13 & 0 & 0.012 & 0 \\
\hline NPL2 & Natural Pist. Tree 2 & 0.08 & 0 & 0.008 & 0 & 0.042 & 0.002 & 234 & 4 & 0.319 & 0.004 \\
\hline NPS2 & Natural Pist. Tree 2 & 0.06 & 0 & 0.006 & 0 & 0.035 & 0.002 & 152 & 3 & 0.321 & 0.003 \\
\hline NPF2 & Natural Pist. Tree 2 & 0.02 & 0 & 0.001 & 0 & 0.007 & 0.001 & 59 & 1 & 0.061 & 0.001 \\
\hline NPL3 & Natural Pist. Tree 3 & 0.07 & 0 & 0.006 & 0 & 0.039 & 0.002 & 184 & 3 & 0.254 & 0.003 \\
\hline NPS3 & Natural Pist. Tree 3 & 0.07 & 0 & 0.007 & 0.001 & 0.04 & 0.002 & 160 & 3 & 0.368 & 0.005 \\
\hline NPF3 & Natural Pist. Tree 3 & 0.02 & 0 & $<0.001$ & 0 & 0.009 & 0.001 & 52 & 1 & 0.051 & 0.001 \\
\hline POL1 & Pomegranate Tree 1 & 0.06 & 0 & 0.005 & 0 & 0.029 & 0.002 & 159 & 3 & 0.21 & 0.003 \\
\hline POS1 & Pomegranate Tree 1 & 0.04 & 0 & 0.003 & 0 & 0.017 & 0.001 & 79 & 1 & 0.139 & 0.002 \\
\hline POF1 & Pomegranate Tree 1 & 0.01 & 0 & $<0.001$ & 0 & $<0.004$ & 0 & 16 & 1 & $<0.003$ & 0 \\
\hline
\end{tabular}


Table A.1, Part 3. Concentrations of Elements in Botanical and Soil Samples (ppm)

\begin{tabular}{|c|c|c|c|c|c|c|c|c|c|c|c|}
\hline Sample Code & Crop/Fruit & Cobalt & $\mathbf{\pm 1 \sigma}$ & Europium & $\mathbf{\pm 1 \boldsymbol { \sigma }}$ & Hafnium & $\mathbf{\pm 1 \boldsymbol { \sigma }}$ & Iron & $\mathbf{\pm 1 \boldsymbol { \sigma }}$ & Lawrencium & $\mathbf{\pm 1 \boldsymbol { \sigma }}$ \\
\hline POL4 & Pomegranate Tree 4 & 0.05 & 0 & 0.003 & 0 & 0.02 & 0.002 & 120 & 2 & 0.151 & 0.002 \\
\hline POS4 & Pomegranate Tree 4 & 0.05 & 0 & 0.002 & 0 & 0.009 & 0.001 & 60 & 1 & 0.097 & 0.002 \\
\hline POF4 & Pomegranate Tree 4 & 0.02 & 0 & $<0.001$ & 0 & $<0.004$ & 0 & 13 & 1 & $<0.003$ & 0 \\
\hline POL5 & Pomegranate Tree 5 & 0.05 & 0 & 0.004 & 0 & 0.021 & 0.002 & 121 & 2 & 0.156 & 0.002 \\
\hline POS5 & Pomegranate Tree 5 & 0.03 & 0 & 0.001 & 0 & 0.007 & 0.001 & 46 & 1 & 0.061 & 0.001 \\
\hline POF5 & Pomegranate Tree 5 & 0.01 & 0 & $<0.001$ & 0 & $<0.003$ & 0 & 16 & 1 & $<0.002$ & 0 \\
\hline NYE & County Soil 1 & 4.08 & 0.09 & 0.975 & 0.026 & 7.392 & 0.2 & 15269 & 207 & 49.91 & 0.374 \\
\hline NYE & County Soil 2 & 3.9 & 0.08 & 0.926 & 0.026 & 6.651 & 0.183 & 15043 & 204 & 50.279 & 0.378 \\
\hline NYE & County Soil 3 & 3.59 & 0.08 & 0.921 & 0.024 & 6.838 & 0.187 & 13986 & 191 & 46.379 & 0.357 \\
\hline Soil XRF & & & & & & & & 15900 & & 53 & \\
\hline
\end{tabular}


Table A.1, Part 4. Concentrations of Elements in Botanical and Soil Samples (ppm)

\begin{tabular}{|c|c|c|c|c|c|c|c|c|c|c|c|}
\hline $\begin{array}{l}\text { Sample } \\
\text { Code }\end{array}$ & Crop/Fruit & Lutetium & $\pm 1 \sigma$ & Magnesium & $\pm 1 \sigma$ & Manganese & $\pm 1 \sigma$ & Nickel & $\pm 1 \sigma$ & Neodymium & $\pm 1 \sigma$ \\
\hline AF1 & Alfalfa & $<0.001$ & 0 & 2711 & 144 & 49.67 & 1.99 & 0.47 & 0.16 & $<0.32$ & 0.01 \\
\hline $\mathrm{AF} 2$ & Alfalfa & $<0.001$ & 0 & 3025 & 149 & 51.44 & 2.05 & 1.51 & 0.3 & $<0.31$ & 0.01 \\
\hline AF3 & Alfalfa & $<0.001$ & 0 & 2664 & 136 & 40.22 & 1.61 & 1.29 & 0.26 & $<0.3$ & 0.01 \\
\hline AF4 & Alfalfa & $<0.001$ & 0 & 2811 & 139 & 47.8 & 1.91 & $<0.41$ & 0.07 & $<0.34$ & 0.01 \\
\hline AF5 & Alfalfa & $<0.001$ & 0 & 2897 & 148 & 45.19 & 1.8 & 0.83 & 0.19 & $<0.31$ & 0.01 \\
\hline ALL1 & Almond Tree 1 & 0.001 & 0 & 4611 & 215 & 21.85 & 0.88 & 2.88 & 0.49 & $<0.25$ & 0.01 \\
\hline ALS1 & Almond Tree 1 & 0.001 & 0 & 672 & 42 & 13.21 & 0.53 & 0.79 & 0.16 & $<0.16$ & 0.01 \\
\hline ALF1 & Almond Tree 1 & 0 & 0 & 1059 & 54 & 7.41 & 0.3 & 3.84 & 0.64 & $<0.27$ & 0.01 \\
\hline ALL2 & Almond Tree 2 & 0.005 & 0 & 6618 & 303 & 23.76 & 0.95 & $<0.63$ & 0.1 & 0.29 & 0.1 \\
\hline ALS2 & Almond Tree 2 & 0 & 0 & 707 & 33 & 7.84 & 0.26 & 4.62 & 0.74 & $<0.09$ & 0 \\
\hline ALF2 & Almond Tree 2 & 0.002 & 0 & 1544 & 64 & 12.24 & 0.41 & 2.38 & 0.42 & $<0.25$ & 0.01 \\
\hline ALF4 & Almond Tree 4 & 0.002 & 0 & 927 & 43 & 9.06 & 0.3 & 2.39 & 0.43 & $<0.28$ & 0.01 \\
\hline ALF5 & Almond Tree 5 & 0.001 & 0 & 1147 & 50 & 8.3 & 0.28 & 2.35 & 0.41 & $<0.2$ & 0.01 \\
\hline ALF6 & Almond Tree 6 & $<0.001$ & 0 & 1178 & 51 & 7.25 & 0.25 & 3.81 & 0.64 & $<0.22$ & 0.01 \\
\hline APL1 & Apple Tree 1 & 0.002 & 0 & 3124 & 124 & 51.86 & 1.69 & $<0.47$ & 0.08 & $<0.21$ & 0.01 \\
\hline APS1 & Apple Tree 1 & $<0.001$ & 0 & 889 & 40 & 16.46 & 0.54 & 1.04 & 0.21 & $<0.22$ & 0.01 \\
\hline APF1 & Apple Tree 1 & $<0.001$ & 0 & 485 & 23 & 2.85 & 0.1 & 2.07 & 0.37 & $<0.18$ & 0.01 \\
\hline APL2 & Apple Tree 2 & 0.003 & 0 & 3165 & 126 & 44.56 & 1.46 & $<0.70$ & 0.12 & 0.61 & 0.16 \\
\hline APS2 & Apple Tree 2 & 0 & 0 & 1131 & 47 & 14.13 & 0.47 & 0.63 & 0.15 & $<0.24$ & 0.02 \\
\hline APF2 & Apple Tree 2 & 0 & 0 & 484 & 23 & 3.1 & 0.11 & 0.45 & 0.16 & $<0.25$ & 0.02 \\
\hline ARS4 & Apricot Tree 4 & $<0.001$ & 0 & 868 & 40 & 12.48 & 0.41 & $<0.26$ & 0.04 & $<0.31$ & 0.02 \\
\hline ARF4 & Apricot Tree 4 & 0.002 & 0 & 822 & 37 & 8.52 & 0.29 & 1.4 & 0.36 & $<0.48$ & 0.03 \\
\hline ARL5 & Apricot Tree 5 & $<0.001$ & 0 & 1190 & 50 & 18.95 & 0.62 & 0.62 & 0.15 & $<0.35$ & 0.02 \\
\hline ARS5 & Apricot Tree 5 & 0.002 & 0 & 3386 & 135 & 62.99 & 2.05 & $<0.62$ & 0.1 & $<0.54$ & 0.04 \\
\hline ARF5 & $\begin{array}{c}\text { Apricot } \\
\text { Comnosite }\end{array}$ & $<0.001$ & 0 & 604 & 28 & 4.15 & 0.14 & 1.62 & 0.33 & $<0.3$ & 0.01 \\
\hline CRL1 & Carob Tree 1 & 0.001 & 0 & 2398 & 100 & 58.51 & 1.91 & 1.41 & 0.29 & $<0.39$ & 0.03 \\
\hline CRS1 & Carob Tree 1 & 0.001 & 0 & 770 & 36 & 6.23 & 0.21 & 0.53 & 0.16 & $<0.25$ & 0.02 \\
\hline CRF1a & Carob Tree 1 & 0 & 0 & 1376 & 57 & 15.11 & 0.5 & 3.41 & 0.6 & $<0.39$ & 0.03 \\
\hline CRF1b & Carob Tree 1 & $<0.001$ & 0 & 1172 & 53 & 18.01 & 0.59 & 2.84 & 0.52 & $<0.4$ & 0.03 \\
\hline CRL2 & Carob Tree 2 & $<0.001$ & 0 & 1786 & 75 & 29.05 & 0.95 & $<0.36$ & 0.06 & $<0.34$ & 0.02 \\
\hline CRS2 & Carob Tree 2 & 0 & 0 & 459 & 25 & 7.22 & 0.24 & 4.52 & 0.79 & $<0.22$ & 0.01 \\
\hline CRF2a & Carob Tree 2 & $<0.001$ & 0 & 1032 & 47 & 13.93 & 0.46 & 2.27 & 0.44 & $<0.45$ & 0.03 \\
\hline CRF2b & Carob Tree 2 & $<0.001$ & 0 & 1011 & 45 & 11.63 & 0.39 & 1.17 & 0.24 & $<0.21$ & 0.01 \\
\hline FIL & Fig Tree 1 & 0.007 & 0.001 & 4247 & 165 & 35.33 & 1.16 & $<0.89$ & 0.15 & 0.65 & 0.2 \\
\hline FIS & Fig Tree 1 & $<0.001$ & 0 & 2786 & 110 & 26.7 & 0.88 & 1.31 & 0.25 & $<0.2$ & 0.01 \\
\hline FIF & Fig Tree 1 & $<0.001$ & 0 & 2876 & 112 & 18.85 & 0.62 & 1.51 & 0.29 & $<0.25$ & 0.01 \\
\hline FIL & Fig Tree 3 & 0.011 & 0.001 & 4572 & 179 & 58.43 & 1.91 & 10.48 & 1.85 & 0.85 & 0.16 \\
\hline FIS & Fig Tree 3 & 0 & 0 & 1425 & 62 & 15.26 & 0.5 & 0.89 & 0.18 & $<0.14$ & 0.01 \\
\hline FIF & Fig Tree 3 & $<0.001$ & 0 & 1446 & 60 & 9.08 & 0.31 & 2.13 & 0.38 & $<0.18$ & 0.01 \\
\hline FIF & Fig Tree 2 & $<0.001$ & 0 & 2520 & 99 & 15.97 & 0.53 & 1.94 & 0.36 & $<0.24$ & 0.01 \\
\hline FIF & Fig Tree 4 & $<0.001$ & 0 & 1562 & 64 & 4.96 & 0.17 & 2.44 & 0.51 & $<0.32$ & 0.01 \\
\hline FIF & Fig Tree 5 & $<0.001$ & 0 & 1840 & 74 & 12.66 & 0.42 & 5.26 & 0.87 & $<0.26$ & 0.01 \\
\hline
\end{tabular}


Table A.1, Part 4. Concentrations of Elements in Botanical and Soil Samples (ppm)

\begin{tabular}{|c|c|c|c|c|c|c|c|c|c|c|c|}
\hline $\begin{array}{l}\text { Sample } \\
\text { Code }\end{array}$ & Crop/Fruit & Lutetium & $\pm 1 \sigma$ & Magnesium & $\pm 1 \sigma$ & Manganese & $\pm 1 \sigma$ & Nickel & $\pm 1 \sigma$ & Neodymium & $\pm 1 \sigma$ \\
\hline GRL1 & Grape Vine 1 & $<0.001$ & 0 & 3683 & 149 & 78.58 & 2.56 & $<0.62$ & 0.1 & $<0.47$ & 0.02 \\
\hline GRS1 & Grape Vine 1 & $<0.001$ & 0 & 2441 & 102 & 29.75 & 0.98 & 1.1 & 0.24 & $<0.25$ & 0.01 \\
\hline GRF1 & Grape Vine 1 & $<0.002$ & 0 & 1919 & 94 & 25.42 & 0.84 & $<0.54$ & 0.09 & $<0.38$ & 0.01 \\
\hline GRL2 & Grape Vine 2 & $<0.001$ & 0 & 2883 & 134 & 92.2 & 3 & $<0.59$ & 0.1 & $<0.38$ & 0.01 \\
\hline GRS2.3 & Grape Vine 2 & $<0.001$ & 0 & 1322 & 96 & 33.6 & 1.11 & 3.35 & 0.6 & $<0.31$ & 0.01 \\
\hline GRS2.4 & Grape Vine 2 & $<0.002$ & 0 & 1345 & 92 & 32.42 & 1.07 & $<0.84$ & 0.14 & $<0.45$ & 0.02 \\
\hline GRF2.2 & Grape Vine 2 & $<0.001$ & 0 & 1209 & 54 & 18.78 & 0.62 & 1.65 & 0.33 & $<0.28$ & 0.01 \\
\hline GRF2.3 & Grape Vine 2 & $<0.001$ & 0 & 1192 & 54 & 19.01 & 0.63 & 1.83 & 0.41 & $<0.33$ & 0.01 \\
\hline NCL1 & Nectarine Tree 1 & 0.002 & 0 & 3584 & 142 & 58.13 & 1.9 & 1.41 & 0.34 & $<0.33$ & 0.01 \\
\hline NCS1 & Nectarine Tree 1 & 0.001 & 0 & 1165 & 59 & 36.92 & 1.21 & 4.49 & 0.78 & $<0.16$ & 0.01 \\
\hline NCF1 & Nectarine Tree 1 & $<0.001$ & 0 & 908 & 40 & 9.66 & 0.32 & 3.75 & 0.69 & $<0.24$ & 0.01 \\
\hline NCL3 & Nectarine Tree 3 & 0.002 & 0 & 2648 & 111 & 67.31 & 2.19 & $<0.58$ & 0.1 & $<0.26$ & 0.01 \\
\hline NCS3 & Nectarine Tree 3 & 0 & 0 & 887 & 40 & 18.82 & 0.62 & 0.72 & 0.15 & $<0.13$ & 0 \\
\hline FO1 & Feed Oats & $<0.001$ & 0 & 1810 & 93 & 66.29 & 2.16 & 3.13 & 0.54 & $<0.36$ & 0.01 \\
\hline FO4 & Feed Oats & $<0.002$ & 0 & 1716 & 89 & 56.49 & 1.84 & 3.52 & 0.6 & $<0.35$ & 0.01 \\
\hline FO6 & Feed Oats & $<0.002$ & 0 & 2064 & 96 & 82.02 & 2.67 & 3.44 & 0.59 & $<0.4$ & 0.01 \\
\hline FO8 & Feed Oats & $<0.001$ & 0 & 2030 & 104 & 79.43 & 2.59 & 2.3 & 0.47 & $<0.56$ & 0.04 \\
\hline PCL & Pecan & $<0.001$ & 0 & 2952 & 122 & 41.9 & 1.37 & $<0.44$ & 0.07 & $<0.25$ & 0.01 \\
\hline PCS & Pecan & $<0.001$ & 0 & 716 & 37 & 11.2 & 0.37 & 1.91 & 0.37 & $<0.14$ & 0.01 \\
\hline PCF & Pecan & $<0.001$ & 0 & 491 & 26 & 4.48 & 0.15 & 2.75 & 0.5 & $<0.2$ & 0.01 \\
\hline GPL1 & Graft Pist. Tree 1 & 0.001 & 0 & 4083 & 160 & 52.24 & 1.71 & $<0.38$ & 0.06 & $<0.43$ & 0.03 \\
\hline GPS1 & Graft Pist. Tree 1 & 0 & 0 & 1018 & 45 & 19.57 & 0.64 & $<0.24$ & 0.04 & $<0.21$ & 0.01 \\
\hline GPF1 & Graft Pist. Tree 1 & $<0.001$ & 0 & 557 & 26 & 4.82 & 0.17 & 9.04 & 1.41 & $<0.39$ & 0.03 \\
\hline GPL2 & Graft Pist. Tree 2 & 0.001 & 0 & 5246 & 203 & 57.31 & 1.87 & 0.41 & 0.13 & $<0.38$ & 0.03 \\
\hline GPS2 & Graft Pist. Tree 2 & 0.005 & 0 & 1034 & 57 & 40.2 & 1.31 & $<0.82$ & 0.14 & 0.42 & 0.1 \\
\hline GPF2 & Graft Pist. Tree 2 & $<0.001$ & 0 & 544 & 25 & 3.68 & 0.13 & 3.37 & 0.54 & $<0.35$ & 0.02 \\
\hline GPL3 & Graft Pist. Tree 3 & 0.002 & 0 & 6508 & 248 & 53.88 & 1.76 & 0.63 & 0.17 & $<0.42$ & 0.03 \\
\hline GPS3 & Graft Pist. Tree 3 & 0.001 & 0 & 781 & 42 & 22.11 & 0.73 & 0.41 & 0.12 & $<0.21$ & 0.01 \\
\hline GPF3 & Graft Pist. Tree 3 & $<0.001$ & 0 & 614 & 28 & 4.08 & 0.14 & 2.19 & 0.37 & $<0.4$ & 0.03 \\
\hline GPL4 & Graft Pist. Tree 4 & 0.002 & 0 & 5283 & 203 & 59.66 & 1.95 & $<0.52$ & 0.08 & $<0.43$ & 0.03 \\
\hline GPS4 & Graft Pist. Tree 4 & 0.002 & 0 & 981 & 57 & 45.55 & 1.49 & 0.38 & 0.14 & 0.24 & 0.09 \\
\hline GPF4 & Graft Pist. Tree 4 & $<0.001$ & 0 & 592 & 28 & 5.22 & 0.18 & 4.94 & 0.77 & $<0.37$ & 0.03 \\
\hline NPL1 & $\begin{array}{c}\text { Natural Pist. Tree } \\
1\end{array}$ & $<0.001$ & 0 & 2837 & 111 & 39.48 & 1.29 & 2.09 & 0.35 & $<0.3$ & 0.02 \\
\hline NPS1 & $\begin{array}{c}\text { Natural Pist. Tree } \\
1\end{array}$ & 0.003 & 0 & 1535 & 65 & 29.41 & 0.96 & $<0.68$ & 0.11 & $<0.29$ & 0.02 \\
\hline NPF1 & $\begin{array}{c}\text { Natural Pist. Tree } \\
1\end{array}$ & 0 & 0 & 672 & 32 & 6.38 & 0.22 & 0.66 & 0.11 & $<0.1$ & 0.01 \\
\hline NPL2 & $\begin{array}{c}\text { Natural Pist. Tree } \\
2 \\
\end{array}$ & 0.002 & 0 & 3766 & 146 & 41.04 & 1.34 & 0.8 & 0.2 & 0.38 & 0.14 \\
\hline NPS2 & $\begin{array}{c}\text { Natural Pist. Tree } \\
2\end{array}$ & 0.002 & 0 & 1353 & 60 & 22.09 & 0.73 & $<0.34$ & 0.05 & 0.17 & 0.08 \\
\hline NPF2 & $\begin{array}{c}\text { Natural Pist. Tree } \\
2\end{array}$ & $<0.001$ & 0 & 1213 & 47 & 9.62 & 0.28 & 1.9 & 0.33 & $<0.36$ & 0.02 \\
\hline NPL3 & $\begin{array}{c}\text { Natural Pist. Tree } \\
3\end{array}$ & 0.002 & 0 & 5176 & 175 & 52.16 & 1.48 & 5.37 & 0.85 & $<0.29$ & 0.02 \\
\hline NPS3 & $\begin{array}{c}\text { Natural Pist. Tree } \\
3\end{array}$ & 0.003 & 0 & 1450 & 64 & 30.23 & 0.86 & 0.7 & 0.24 & $<0.3$ & 0.02 \\
\hline NPF3 & $\begin{array}{c}\text { Natural Pist. Tree } \\
3\end{array}$ & $<0.001$ & 0 & 1098 & 42 & 10.06 & 0.29 & 2.1 & 0.43 & $<0.41$ & 0.03 \\
\hline POL1 & $\begin{array}{c}\text { Pomegranate } \\
\text { Tree } 1\end{array}$ & $<0.001$ & 0 & 2360 & 90 & 48.5 & 1.37 & $<0.32$ & 0.05 & $<0.41$ & 0.03 \\
\hline
\end{tabular}


Table A.1, Part 4. Concentrations of Elements in Botanical and Soil Samples (ppm)

\begin{tabular}{|c|c|c|c|c|c|c|c|c|c|c|c|}
\hline $\begin{array}{c}\text { Sample } \\
\text { Code }\end{array}$ & Crop/Fruit & Lutetium & $\pm 1 \sigma$ & Magnesium & $\pm 1 \sigma$ & Manganese & $\pm 1 \sigma$ & Nickel & $\pm 1 \sigma$ & Neodymium & $\pm 1 \sigma$ \\
\hline Pos1 & $\begin{array}{c}\text { Pomegranate } \\
\text { Tree } 1\end{array}$ & 0.001 & 0 & 631 & 35 & 9.36 & 0.27 & 0.74 & 0.14 & $<0.23$ & 0.02 \\
\hline POF1 & $\begin{array}{c}\text { Pomegranate } \\
\text { Tree } 1\end{array}$ & $<0.001$ & 0 & 873 & 40 & 6.91 & 0.21 & 6.49 & 1.14 & $<0.51$ & 0.03 \\
\hline POL4 & $\begin{array}{c}\text { Pomegranate } \\
\text { Tree } 4\end{array}$ & 0.001 & 0 & 1884 & 79 & 38.43 & 1.09 & 0.67 & 0.17 & $<0.43$ & 0.03 \\
\hline POS4 & $\begin{array}{c}\text { Pomegranate } \\
\text { Tree } 4\end{array}$ & 0 & 0 & 770 & 40 & 13.69 & 0.4 & 0.88 & 0.18 & $<0.29$ & 0.02 \\
\hline POF4 & $\begin{array}{c}\text { Pomegranate } \\
\text { Tree } 4\end{array}$ & $<0.001$ & 0 & 649 & 33 & 5.23 & 0.16 & 8.6 & 1.49 & $<0.5$ & 0.03 \\
\hline POL5 & $\begin{array}{c}\text { Pomegranate } \\
\text { Tree } 5\end{array}$ & 0.001 & 0 & 2007 & 78 & 24.63 & 0.71 & $<0.28$ & 0.04 & $<0.42$ & 0.03 \\
\hline POS5 & $\begin{array}{c}\text { Pomegranate } \\
\text { Tree } 5\end{array}$ & $<0.001$ & 0 & 787 & 36 & 10.37 & 0.3 & 0.24 & 0.1 & $<0.29$ & 0.02 \\
\hline POF5 & $\begin{array}{c}\text { Pomegranate } \\
\text { Tree } 5\end{array}$ & $<0.001$ & 0 & 788 & 40 & 5.95 & 0.18 & 2.52 & 0.41 & $<0.44$ & 0.03 \\
\hline NYE & County Soil 1 & 0.39 & 0.017 & 7578 & 1048 & 490.8 & 15.3 & $<27.19$ & 4.57 & 40.59 & 2.87 \\
\hline NYE & County Soil 2 & 0.362 & 0.017 & 7534 & 1116 & 479 & 15 & $<27.26$ & 4.58 & 35.54 & 2.63 \\
\hline NYE & County Soil 3 & 0.311 & 0.017 & 9643 & 1249 & 461.1 & 14.4 & $<26.13$ & 4.39 & 29.75 & 2.38 \\
\hline Soil XRF & & & & 495 & & 33000 & & 10 & & 36 & \\
\hline
\end{tabular}


Table A.1, Part 5. Concentrations of Elements in Botanical and Soil Samples (ppm)

\begin{tabular}{|c|c|c|c|c|c|c|c|c|c|c|c|}
\hline Sample Code & Crop/Fruit & Potassium & $\pm 1 \sigma$ & Rubidium & $\pm 1 \sigma$ & Samarium & $\pm 1 \sigma$ & Scandium & $\pm 1 \sigma$ & Sodium(1) & $\pm 1 \sigma$ \\
\hline AF1 & Alfalfa & 36344 & 1491 & 16.02 & 0.54 & 0.009 & 0.001 & 0.005 & 0 & 1035 & 131 \\
\hline AF2 & Alfalfa & 36498 & 1418 & 16.42 & 0.56 & 0.024 & 0.001 & 0.02 & 0 & 853 & 106 \\
\hline AF3 & Alfalfa & 35244 & 1353 & 16.07 & 0.54 & 0.007 & 0.001 & 0.004 & 0 & 643 & 80 \\
\hline AF4 & Alfalfa & 33995 & 1307 & 16.02 & 0.54 & 0.008 & 0.001 & 0.005 & 0 & 701 & 88 \\
\hline AF5 & Alfalfa & 33788 & 1303 & 15.61 & 0.53 & 0.009 & 0.001 & 0.006 & 0 & 824 & 103 \\
\hline ALL1 & Almond Tree 1 & 24011 & 972 & 10.77 & 0.37 & 0.036 & 0.001 & 0.041 & 0.001 & 1400 & 177 \\
\hline ALS1 & Almond Tree 1 & 4104 & 227 & 2.16 & 0.08 & 0.016 & 0.001 & 0.017 & 0 & 665 & 84 \\
\hline ALF1 & Almond Tree 1 & 25723 & 1015 & 16.94 & 0.58 & 0.018 & 0.001 & 0.02 & 0 & 433 & 55 \\
\hline ALL2 & Almond Tree 2 & 22646 & 877 & 9.14 & 0.32 & 0.086 & 0.003 & 0.105 & 0.002 & 3286 & 408 \\
\hline ALS2 & Almond Tree 2 & 5452 & 223 & 1.99 & 0.07 & 0.008 & 0 & 0.01 & 0 & 195 & 20 \\
\hline ALF2 & Almond Tree 2 & 25614 & 826 & 12.98 & 0.44 & 0.035 & 0.002 & 0.04 & 0.001 & 425 & 44 \\
\hline ALF4 & Almond Tree 4 & 28633 & 913 & 16.27 & 0.55 & 0.029 & 0.001 & 0.032 & 0.001 & 561 & 58 \\
\hline ALF5 & Almond Tree 5 & 23996 & 774 & 15.48 & 0.52 & 0.024 & 0.001 & 0.025 & 0 & 581 & 60 \\
\hline ALF6 & Almond Tree 6 & 26078 & 837 & 17.09 & 0.58 & 0.02 & 0.001 & 0.02 & 0 & 683 & 70 \\
\hline APL1 & Apple Tree 1 & 25799 & 857 & 19.4 & 0.65 & 0.043 & 0.001 & 0.064 & 0.001 & 191 & 20 \\
\hline APS1 & Apple Tree 1 & 6801 & 261 & 6.68 & 0.23 & 0.008 & 0.001 & 0.008 & 0 & 76 & 8 \\
\hline APF1 & Apple Tree 1 & 14804 & 482 & 17.13 & 0.58 & $<0.001$ & 0 & 0.001 & 0 & 9 & 2 \\
\hline APL2 & Apple Tree 2 & 20106 & 692 & 15.81 & 0.68 & 0.072 & 0.003 & 0.091 & 0.002 & 466 & 48 \\
\hline APS2 & Apple Tree 2 & 5674 & 230 & 5.17 & 0.22 & 0.007 & 0 & 0.009 & 0 & 77 & 8 \\
\hline APF2 & Apple Tree 2 & 15865 & 518 & 18.89 & 0.8 & 0.005 & 0 & 0.005 & 0 & 59 & 6 \\
\hline ARS4 & Apricot Tree 4 & 6119 & 241 & 9.94 & 0.42 & 0.007 & 0.001 & 0.008 & 0 & 73 & 8 \\
\hline ARF4 & Apricot Tree 4 & 28477 & 907 & 45.6 & 1.92 & 0.032 & 0.002 & 0.032 & 0.001 & 189 & 20 \\
\hline ARL5 & Apricot Tree 5 & 5342 & 226 & 5.71 & 0.25 & 0.008 & 0.001 & 0.009 & 0 & 51 & 6 \\
\hline ARS5 & Apricot Tree 5 & 48417 & 1532 & 26.26 & 1.11 & 0.042 & 0.001 & 0.051 & 0.001 & 127 & 14 \\
\hline ARF5 & Apricot Composite & 27552 & 874 & 31.45 & 1.06 & 0.009 & 0.001 & 0.01 & 0 & 54 & 6 \\
\hline CRL1 & Carob Tree 1 & 14379 & 524 & 11.95 & 0.51 & 0.028 & 0.001 & 0.041 & 0.001 & 156 & 17 \\
\hline CRS1 & Carob Tree 1 & 5793 & 226 & 3.69 & 0.17 & 0.021 & 0.001 & 0.022 & 0 & 88 & 10 \\
\hline CRF1a & Carob Tree 1 & 20473 & 674 & 14.88 & 0.63 & 0.012 & 0.001 & 0.016 & 0 & 55 & 7 \\
\hline CRF1b & Carob Tree 1 & 19698 & 651 & 16.66 & 0.71 & 0.009 & 0.001 & 0.012 & 0 & 44 & 6 \\
\hline CRL2 & Carob Tree 2 & 12408 & 449 & 12.01 & 0.51 & 0.023 & 0.001 & 0.033 & 0.001 & 118 & 13 \\
\hline CRS2 & Carob Tree 2 & 3004 & 162 & 2.93 & 0.14 & 0.011 & 0 & 0.011 & 0 & 57 & 6 \\
\hline CRF2a & Carob Tree 2 & 15891 & 534 & 20.28 & 0.86 & 0.001 & 0.001 & 0.003 & 0 & $<6$ & 1 \\
\hline CRF2b & Carob Tree 2 & 17187 & 573 & 17.97 & 0.63 & 0.002 & 0 & 0.003 & 0 & 15 & 4 \\
\hline FIL & Fig Tree 1 & 21982 & 763 & 9.91 & 0.45 & 0.109 & 0.004 & 0.125 & 0.002 & 835 & 86 \\
\hline FIS & Fig Tree 1 & 17048 & 592 & 8.63 & 0.3 & 0.007 & 0 & 0.008 & 0 & 147 & 16 \\
\hline FIF & Fig Tree 1 & 19195 & 637 & 12.71 & 0.45 & 0.006 & 0.001 & 0.007 & 0 & 280 & 29 \\
\hline FIL & Fig Tree 3 & 23306 & 802 & 17.38 & 0.63 & 0.16 & 0.004 & 0.161 & 0.003 & 963 & 99 \\
\hline FIS & Fig Tree 3 & 9510 & 368 & 4.62 & 0.17 & 0.012 & 0 & 0.011 & 0 & 359 & 37 \\
\hline FIF & Fig Tree 3 & 13556 & 470 & 9.08 & 0.32 & 0.002 & 0 & 0.003 & 0 & 222 & 23 \\
\hline FIF & Fig Tree 2 & 18062 & 633 & 10.93 & 0.38 & 0.003 & 0 & 0.005 & 0 & 375 & 39 \\
\hline FIF & Fig Tree 4 & 16368 & 556 & 9.43 & 0.35 & 0.002 & 0.001 & 0.004 & 0 & 209 & 22 \\
\hline FIF & Fig Tree 5 & 18046 & 601 & 9.37 & 0.32 & 0.006 & 0.001 & 0.008 & 0 & 244 & 25 \\
\hline
\end{tabular}


Table A.1, Part 5. Concentrations of Elements in Botanical and Soil Samples (ppm)

\begin{tabular}{|c|c|c|c|c|c|c|c|c|c|c|c|}
\hline Sample Code & Crop/Fruit & Potassium & $\pm 1 \sigma$ & Rubidium & $\pm 1 \sigma$ & Samarium & $\pm 1 \sigma$ & Scandium & $\pm 1 \sigma$ & Sodium(1) & $\pm 1 \sigma$ \\
\hline GRL1 & Grape Vine 1 & 8641 & 377 & 5.66 & 0.22 & 0.04 & 0.001 & 0.053 & 0.001 & 471 & 49 \\
\hline GRS1 & Grape Vine 1 & 9707 & 431 & 5.82 & 0.21 & 0.01 & 0.001 & 0.012 & 0 & 1515 & 155 \\
\hline GRF1 & Grape Vine 1 & 22322 & 818 & 18.65 & 0.66 & 0.01 & 0.001 & 0.009 & 0 & 5106 & 523 \\
\hline GRL2 & Grape Vine 2 & 8706 & 402 & 6.37 & 0.24 & 0.038 & 0.001 & 0.052 & 0.001 & 546 & 56 \\
\hline GRS2.3 & Grape Vine 2 & 22003 & 829 & 27.09 & 0.94 & $<0.003$ & 0 & 0.004 & 0 & 5389 & 552 \\
\hline GRS2.4 & Grape Vine 2 & 21528 & 824 & 25.7 & 0.91 & $<0.004$ & 0 & 0.003 & 0 & 6048 & 619 \\
\hline GRF2.2 & Grape Vine 2 & 21840 & 711 & 20.78 & 0.72 & 0.003 & 0 & 0.004 & 0 & 218 & 23 \\
\hline GRF2.3 & Grape Vine 2 & 22590 & 730 & 20.37 & 0.72 & 0.003 & 0.001 & 0.005 & 0 & 223 & 23 \\
\hline NCL1 & Nectarine Tree 1 & 41952 & 1340 & 36.68 & 1.27 & 0.041 & 0.002 & 0.06 & 0.001 & 117 & 13 \\
\hline NCS1 & Nectarine Tree 1 & 3085 & 197 & 4.38 & 0.16 & 0.017 & 0 & 0.01 & 0 & 61 & 7 \\
\hline NCF1 & Nectarine Tree 1 & 21403 & 688 & 38.97 & 1.35 & 0.006 & 0 & 0.007 & 0 & 27 & 3 \\
\hline NCL3 & Nectarine Tree 3 & 39257 & 1254 & 38.97 & 1.35 & 0.04 & 0.001 & 0.061 & 0.001 & 115 & 13 \\
\hline NCS3 & Nectarine Tree 3 & 6616 & 253 & 9.59 & 0.34 & 0.006 & 0 & 0.006 & 0 & 30 & 4 \\
\hline FO1 & Feed Oats & 7808 & 375 & 7.49 & 0.27 & 0.012 & 0.001 & 0.01 & 0 & 863 & 89 \\
\hline FO4 & Feed Oats & 10794 & 459 & 7.71 & 0.27 & 0.015 & 0.001 & 0.018 & 0 & 1024 & 106 \\
\hline FO6 & Feed Oats & 8042 & 408 & 6.12 & 0.23 & 0.01 & 0.001 & 0.014 & 0 & 770 & 80 \\
\hline FO8 & Feed Oats & 9850 & 438 & 5.34 & 0.25 & 0.006 & 0.001 & 0.009 & 0 & 878 & 91 \\
\hline $\mathrm{PCL}$ & Pecan & 23751 & 847 & 11.42 & 0.4 & 0.024 & 0.001 & 0.034 & 0.001 & 82 & 11 \\
\hline PCS & Pecan & 6322 & 282 & 4.02 & 0.15 & 0.01 & 0 & 0.011 & 0 & 67 & 8 \\
\hline PCF & Pecan & 13012 & 439 & 10.91 & 0.38 & $<0.001$ & 0 & 0.001 & 0 & 9 & 2 \\
\hline GPL1 & Graft Pist. Tree 1 & 19513 & 714 & 6.59 & 0.29 & 0.035 & 0.001 & 0.042 & 0.001 & 101 & 12 \\
\hline GPS1 & Graft Pist. Tree 1 & 8448 & 307 & 3.43 & 0.16 & 0.008 & 0 & 0.008 & 0 & 44 & 6 \\
\hline GPF1 & Graft Pist. Tree 1 & 14748 & 491 & 11.33 & 0.48 & 0.003 & 0 & 0.003 & 0 & 15 & 3 \\
\hline GPL2 & Graft Pist. Tree 2 & 16949 & 631 & 7.89 & 0.34 & 0.03 & 0.001 & 0.036 & 0.001 & 82 & 10 \\
\hline GPS2 & Graft Pist. Tree 2 & 5045 & 292 & 3.27 & 0.19 & 0.093 & 0.002 & 0.096 & 0.002 & 150 & 16 \\
\hline GPF2 & Graft Pist. Tree 2 & 16284 & 535 & 10.96 & 0.47 & 0.003 & 0 & 0.004 & 0 & 9 & 2 \\
\hline GPL3 & Graft Pist. Tree 3 & 22504 & 800 & 11.02 & 0.48 & 0.035 & 0.001 & 0.044 & 0.001 & 127 & 15 \\
\hline GPS3 & Graft Pist. Tree 3 & 7577 & 292 & 4.07 & 0.18 & 0.02 & 0.001 & 0.02 & 0 & 113 & 12 \\
\hline GPF3 & Graft Pist. Tree 3 & 16237 & 533 & 13.09 & 0.56 & 0.001 & 0 & 0.002 & 0 & 11 & 2 \\
\hline GPL4 & Graft Pist. Tree 4 & 20704 & 715 & 13.33 & 0.58 & 0.059 & 0.002 & 0.07 & 0.001 & 294 & 31 \\
\hline GPS4 & Graft Pist. Tree 4 & 6037 & 275 & 4.94 & 0.23 & 0.044 & 0.001 & 0.045 & 0.001 & 245 & 26 \\
\hline GPF4 & Graft Pist. Tree 4 & 15827 & 517 & 13.07 & 0.55 & 0.004 & 0 & 0.004 & 0 & 25 & 3 \\
\hline NPL1 & Natural Pist. Tree 1 & 12511 & 469 & 24.21 & 1.02 & 0.006 & 0 & 0.008 & 0 & 118 & 13 \\
\hline NPS1 & Natural Pist. Tree 1 & 9228 & 355 & 8.52 & 0.38 & 0.05 & 0.001 & 0.045 & 0.001 & 103 & 11 \\
\hline NPF1 & Natural Pist. Tree 1 & 15121 & 505 & 7.92 & 0.33 & 0.002 & 0 & 0.002 & 0 & 18 & 4 \\
\hline NPL2 & Natural Pist. Tree 2 & 10212 & 409 & 7.32 & 0.33 & 0.048 & 0.002 & 0.066 & 0.001 & 141 & 15 \\
\hline NPS2 & Natural Pist. Tree 2 & 6124 & 262 & 4 & 0.19 & 0.05 & 0.001 & 0.043 & 0.001 & 112 & 12 \\
\hline NPF2 & Natural Pist. Tree 2 & 19007 & 554 & 17.13 & 0.72 & 0.01 & 0.001 & 0.012 & 0 & 40 & 5 \\
\hline NPL3 & Natural Pist. Tree 3 & 11092 & 384 & 6.77 & 0.3 & 0.038 & 0.001 & 0.052 & 0.001 & 141 & 14 \\
\hline NPS3 & Natural Pist. Tree 3 & 9392 & 347 & 4.86 & 0.23 & 0.053 & 0.001 & 0.048 & 0.001 & 84 & 8 \\
\hline NPF3 & Natural Pist. Tree 3 & 20871 & 602 & 14.02 & 0.6 & 0.008 & 0.001 & 0.01 & 0 & 35 & 4 \\
\hline POL1 & Pomegranate Tree 1 & 10203 & 429 & 3.85 & 0.18 & 0.031 & 0.001 & 0.043 & 0.001 & 94 & 11 \\
\hline
\end{tabular}


Table A.1, Part 5. Concentrations of Elements in Botanical and Soil Samples (ppm)

\begin{tabular}{|c|c|c|c|c|c|c|c|c|c|c|c|}
\hline Sample Code & Crop/Fruit & Potassium & $\mathbf{\pm 1 \sigma}$ & Rubidium & $\mathbf{\pm 1 \sigma}$ & Samarium & $\mathbf{\pm 1 \sigma}$ & Scandium & $\mathbf{\pm 1 \sigma}$ & Sodium(1) & $\mathbf{\pm 1 \boldsymbol { \sigma }}$ \\
\hline POS1 & Pomegranate Tree 1 & 6901 & 273 & 2.86 & 0.13 & 0.021 & 0 & 0.021 & 0 & 133 & 13 \\
\hline POF1 & Pomegranate Tree 1 & 16892 & 540 & 7.23 & 0.33 & $<0.003$ & 0 & 0 & 0 & 41 & 6 \\
\hline POL4 & Pomegranate Tree 4 & 14728 & 557 & 6.04 & 0.27 & 0.022 & 0.001 & 0.029 & 0.001 & 78 & 10 \\
\hline POS4 & Pomegranate Tree 4 & 8515 & 337 & 3.57 & 0.17 & 0.015 & 0 & 0.015 & 0 & 126 & 12 \\
\hline POF4 & Pomegranate Tree 4 & 16565 & 521 & 7.56 & 0.34 & $<0.002$ & 0 & 0 & 0 & 113 & 11 \\
\hline POL5 & Pomegranate Tree 5 & 11200 & 428 & 4.31 & 0.2 & 0.025 & 0.001 & 0.03 & 0.001 & 70 & 9 \\
\hline POS5 & Pomegranate Tree 5 & 7832 & 306 & 2.89 & 0.14 & 0.01 & 0 & 0.01 & 0 & 116 & 12 \\
\hline POF5 & Pomegranate Tree 5 & 17808 & 552 & 8.17 & 0.36 & $<0.001$ & 0 & 0 & 0 & 82 & 9 \\
\hline NYE & County Soil 1 & 35493 & 2345 & 129.58 & 5.5 & 5.766 & 0.096 & 4.553 & 0.077 & 19979 & 392 \\
\hline NYE & County Soil 2 & 31258 & 2016 & 129.04 & 5.52 & 5.593 & 0.098 & 4.567 & 0.077 & 20075 & 394 \\
\hline NYE & County Soil 3 & 31609 & 2316 & 128.87 & 5.57 & 5.443 & 0.095 & 4.134 & 0.07 & 19639 & 386 \\
\hline Soil XRF & & 20000 & & 136 & & & & 6 & & 2100 & \\
\hline
\end{tabular}

1) Sodium measured in unashed samples 
Table A.1, Part 6. Concentrations of Elements in Botanical and Soil Samples (ppm)

\begin{tabular}{|c|c|c|c|c|c|c|c|c|c|c|c|}
\hline Sample Code & Crop/Fruit & Sodium $^{(2)}$ & $\pm 1 \sigma$ & Strontium & $\pm 1 \sigma$ & Tantalum & $\pm 1 \sigma$ & Terbium & $\pm 1 \sigma$ & Thorium & $\pm 1 \sigma$ \\
\hline AF1 & Alfalfa & 1068 & 29 & 130.45 & 9.04 & $<0.001$ & 0 & $<0.001$ & 0 & 0.011 & 0.001 \\
\hline AF2 & Alfalfa & 820 & 23 & 132.5 & 9.18 & 0.003 & 0 & $<0.002$ & 0 & 0.05 & 0.002 \\
\hline AF3 & Alfalfa & 750 & 21 & 119.85 & 8.3 & $<0.001$ & 0 & $<0.001$ & 0 & 0.009 & 0.001 \\
\hline AF4 & Alfalfa & 713 & 20 & 136.02 & 9.43 & $<0.001$ & 0 & $<0.002$ & 0 & 0.01 & 0.002 \\
\hline AF5 & Alfalfa & 754 & 21 & 136.58 & 9.45 & $<0.001$ & 0 & $<0.001$ & 0 & 0.011 & 0.001 \\
\hline ALL1 & Almond Tree 1 & 1556 & 42 & 232.93 & 16.08 & 0.007 & 0.001 & 0.004 & 0.001 & 0.075 & 0.002 \\
\hline ALS1 & Almond Tree 1 & 678 & 19 & 222.54 & 15.36 & 0.003 & 0 & $<0.001$ & 0 & 0.032 & 0.001 \\
\hline ALF1 & Almond Tree 1 & 419 & 12 & 15.4 & 1.36 & 0.004 & 0 & $<0.002$ & 0 & 0.044 & 0.002 \\
\hline ALL2 & Almond Tree 2 & 3474 & 94 & 234.03 & 16.23 & 0.019 & 0.001 & 0.008 & 0.001 & 0.238 & 0.003 \\
\hline ALS2 & Almond Tree 2 & 179 & 5 & 102.38 & 7.07 & 0.002 & 0 & $<0.001$ & 0 & 0.02 & 0.001 \\
\hline ALF2 & Almond Tree 2 & 393 & 11 & 21.5 & 1.62 & 0.008 & 0.001 & 0.005 & 0.001 & 0.125 & 0.002 \\
\hline ALF4 & Almond Tree 4 & 454 & 12 & 20.8 & 1.64 & 0.006 & 0.001 & 0.003 & 0.001 & 0.083 & 0.002 \\
\hline ALF5 & Almond Tree 5 & 529 & 14 & 26.93 & 2 & 0.005 & 0.001 & 0.002 & 0.001 & 0.058 & 0.002 \\
\hline ALF6 & Almond Tree 6 & 605 & 16 & 21.85 & 1.65 & 0.004 & 0.001 & $<0.002$ & 0 & 0.053 & 0.001 \\
\hline APL1 & Apple Tree 1 & 188 & 5 & 151.39 & 10.47 & 0.01 & 0.001 & 0.005 & 0.001 & 0.114 & 0.002 \\
\hline APS1 & Apple Tree 1 & 74 & 2 & 173.12 & 11.95 & 0.001 & 0 & $<0.001$ & 0 & 0.019 & 0.001 \\
\hline APF1 & Apple Tree 1 & 8 & 0 & 2.29 & 0.54 & $<0.001$ & 0 & $<0.001$ & 0 & $<0.002$ & 0 \\
\hline APL2 & Apple Tree 2 & 429 & 19 & 67.92 & 5.48 & 0.015 & 0.001 & 0.01 & 0.001 & 0.192 & 0.003 \\
\hline APS2 & Apple Tree 2 & 67 & 3 & 97.46 & 7.65 & $<0.001$ & 0 & $<0.001$ & 0 & 0.018 & 0.001 \\
\hline APF2 & Apple Tree 2 & 65 & 3 & 1.59 & 0.38 & $<0.001$ & 0 & $<0.001$ & 0 & 0.013 & 0.001 \\
\hline ARS4 & Apricot Tree 4 & 65 & 3 & 69.39 & 5.46 & $<0.001$ & 0 & $<0.001$ & 0 & 0.015 & 0.001 \\
\hline ARF4 & Apricot Tree 4 & 149 & 7 & 8.1 & 1.2 & 0.007 & 0.001 & 0.006 & 0.001 & 0.106 & 0.003 \\
\hline ARL5 & Apricot Tree 5 & 56 & 3 & 117.45 & 9.23 & $<0.001$ & 0 & $<0.002$ & 0 & 0.018 & 0.002 \\
\hline ARS5 & Apricot Tree 5 & 124 & 6 & 102.58 & 8.16 & 0.009 & 0.001 & $<0.003$ & 0 & 0.096 & 0.003 \\
\hline ARF5 & Apricot Composite & 45 & 1 & 7.77 & 1.04 & $<0.002$ & 0 & $<0.002$ & 0 & 0.019 & 0.002 \\
\hline CRL1 & Carob Tree 1 & 145 & 7 & 105.41 & 8.29 & 0.006 & 0.001 & 0.003 & 0.001 & 0.07 & 0.002 \\
\hline CRS1 & Carob Tree 1 & 86 & 4 & 115.66 & 9.11 & 0.004 & 0.001 & $<0.002$ & 0 & 0.041 & 0.001 \\
\hline CRF1a & Carob Tree 1 & 48 & 2 & 48.01 & 3.84 & 0.002 & 0 & $<0.002$ & 0 & 0.038 & 0.002 \\
\hline CRF1b & Carob Tree 1 & 41 & 2 & 34.28 & 2.81 & $<0.001$ & 0 & $<0.002$ & 0 & 0.025 & 0.002 \\
\hline CRL2 & Carob Tree 2 & 111 & 5 & 57.73 & 4.62 & 0.005 & 0.001 & 0.002 & 0.001 & 0.057 & 0.002 \\
\hline CRS2 & Carob Tree 2 & 53 & 2 & 47.46 & 3.78 & $<0.001$ & 0 & $<0.002$ & 0 & 0.023 & 0.001 \\
\hline CRF2a & Carob Tree 2 & 11 & 1 & 29.7 & 2.51 & $<0.002$ & 0 & $<0.002$ & 0 & $<0.004$ & 0 \\
\hline CRF2b & Carob Tree 2 & 11 & 0 & 25.24 & 1.75 & $<0.001$ & 0 & $<0.001$ & 0 & 0.004 & 0.001 \\
\hline FIL & Fig Tree 1 & 898 & 39 & 152.56 & 12.11 & 0.021 & 0.002 & 0.016 & 0.002 & 0.278 & 0.005 \\
\hline FIS & Fig Tree 1 & 165 & 3 & 106.85 & 6.99 & 0.002 & 0 & $<0.001$ & 0 & 0.015 & 0.001 \\
\hline FIF & Fig Tree 1 & 284 & 5 & 68.16 & 4.5 & 0.001 & 0 & $<0.001$ & 0 & 0.016 & 0.001 \\
\hline FIL & Fig Tree 3 & 1474 & 27 & 174.03 & 11.5 & 0.034 & 0.002 & 0.02 & 0.002 & 0.392 & 0.006 \\
\hline FIS & Fig Tree 3 & 351 & 6 & 140.02 & 9.14 & 0.002 & 0 & 0.001 & 0 & 0.022 & 0.001 \\
\hline FIF & Fig Tree 3 & 221 & 4 & 29.43 & 1.99 & $<0.001$ & 0 & $<0.001$ & 0 & 0.007 & 0.001 \\
\hline FIF & Fig Tree 2 & 396 & 7 & 65.39 & 4.31 & $<0.001$ & 0 & $<0.001$ & 0 & 0.011 & 0.001 \\
\hline FIF & Fig Tree 4 & 221 & 4 & 52.33 & 3.61 & $<0.002$ & 0 & $<0.002$ & 0 & 0.008 & 0.002 \\
\hline FIF & Fig Tree 5 & 228 & 6 & 41.08 & 2.95 & 0.007 & 0.001 & $<0.002$ & 0 & 0.019 & 0.002 \\
\hline
\end{tabular}


Table A.1, Part 6. Concentrations of Elements in Botanical and Soil Samples (ppm)

\begin{tabular}{|c|c|c|c|c|c|c|c|c|c|c|c|}
\hline Sample Code & Crop/Fruit & Sodium $^{(2)}$ & $\pm 1 \sigma$ & Strontium & $\pm 1 \sigma$ & Tantalum & $\pm 1 \sigma$ & Terbium & $\pm 1 \sigma$ & Thorium & $\pm 1 \sigma$ \\
\hline GRL1 & Grape Vine 1 & 543 & 10 & 188.38 & 12.34 & 0.008 & 0.001 & $<0.002$ & 0 & 0.101 & 0.003 \\
\hline GRF1 & Grape Vine 1 & 5490 & 100 & 94.29 & 6.23 & $<0.001$ & 0 & $<0.002$ & 0 & 0.019 & 0.002 \\
\hline GRL2 & Grape Vine 2 & 555 & 10 & 164.35 & 10.78 & 0.008 & 0.001 & 0.004 & 0.001 & 0.093 & 0.002 \\
\hline GRS2.4 & Grape Vine 2 & 6679 & 121 & 79.05 & 5.38 & $<0.002$ & 0 & $<0.003$ & 0 & $<0.006$ & 0 \\
\hline GRF2.2 & Grape Vine 2 & 218 & 4 & 30.84 & 2.13 & $<0.001$ & 0 & $<0.001$ & 0 & 0.007 & 0.001 \\
\hline GRF2.3 & Grape Vine 2 & 238 & 4 & 32.12 & 2.28 & $<0.001$ & 0 & $<0.002$ & 0 & 0.01 & 0.002 \\
\hline NCL1 & Nectarine Tree 1 & 126 & 2 & 70.3 & 4.7 & 0.009 & 0.001 & 0.005 & 0.001 & 0.121 & 0.002 \\
\hline NCS1 & Nectarine Tree 1 & 61 & 1 & 165.6 & 10.82 & 0.003 & 0 & $<0.001$ & 0 & 0.023 & 0.001 \\
\hline NCF1 & Nectarine Tree 1 & 22 & 0 & 6.29 & 0.84 & $<0.001$ & 0 & $<0.002$ & 0 & 0.012 & 0.001 \\
\hline NCL3 & Nectarine Tree 3 & 118 & 2 & 57.78 & 3.86 & 0.009 & 0.001 & 0.005 & 0.001 & 0.115 & 0.002 \\
\hline NCS3 & Nectarine Tree 3 & 26 & 0 & 71.37 & 4.68 & $<0.001$ & 0 & $<0.001$ & 0 & 0.014 & 0.001 \\
\hline FO1 & Feed Oats & 861 & 24 & 25.09 & 1.95 & $<0.001$ & 0 & $<0.002$ & 0 & 0.024 & 0.002 \\
\hline $\mathrm{FO} 4$ & Feed Oats & 1120 & 31 & 20 & 1.65 & 0.003 & 0.001 & $<0.002$ & 0 & 0.041 & 0.002 \\
\hline FO6 & Feed Oats & 969 & 26 & 30.08 & 2.4 & 0.003 & 0.001 & $<0.002$ & 0 & 0.037 & 0.002 \\
\hline FO8 & Feed Oats & 750 & 33 & 16.74 & 1.57 & $<0.002$ & 0 & $<0.002$ & 0 & 0.017 & 0.002 \\
\hline $\mathrm{PCL}$ & Pecan & 95 & 2 & 98.26 & 6.45 & 0.005 & 0 & 0.003 & 0.001 & 0.064 & 0.002 \\
\hline PCS & Pecan & 68 & 1 & 98.48 & 6.45 & $<0.001$ & 0 & $<0.001$ & 0 & 0.022 & 0.001 \\
\hline PCF & Pecan & 19 & 0 & 7.15 & 0.73 & $<0.001$ & 0 & $<0.001$ & 0 & $<0.003$ & 0 \\
\hline GPL1 & Graft Pist. Tree 1 & 97 & 3 & 135.94 & 11.91 & 0.005 & 0.001 & 0.004 & 0.001 & 0.087 & 0.002 \\
\hline GPF1 & Graft Pist. Tree 1 & 15 & 0 & 10.62 & 1.55 & $<0.001$ & 0 & $<0.001$ & 0 & 0.006 & 0.001 \\
\hline GPL2 & Graft Pist. Tree 2 & 84 & 2 & 161.37 & 14.12 & 0.005 & 0.001 & 0.004 & 0.001 & 0.076 & 0.002 \\
\hline GPS2 & Graft Pist. Tree 2 & 188 & 8 & 167.8 & 13.3 & 0.013 & 0.002 & 0.013 & 0.002 & 0.219 & 0.004 \\
\hline GPF2 & Graft Pist. Tree 2 & 18 & 0 & 10.34 & 1.42 & $<0.001$ & 0 & $<0.001$ & 0 & 0.007 & 0.001 \\
\hline GPL3 & Graft Pist. Tree 3 & 128 & 3 & 210.43 & 18.35 & 0.006 & 0.001 & $<0.003$ & 0 & 0.087 & 0.002 \\
\hline GPS3 & Graft Pist. Tree 3 & 96 & 2 & 153.72 & 13.4 & 0.003 & 0.001 & 0.002 & 0.001 & 0.05 & 0.002 \\
\hline GPF3 & Graft Pist. Tree 3 & 14 & 0 & 6.3 & 0.93 & $<0.001$ & 0 & $<0.002$ & 0 & 0.002 & 0.001 \\
\hline GPL4 & Graft Pist. Tree 4 & 288 & 7 & 147.26 & 12.94 & 0.013 & 0.001 & 0.008 & 0.001 & 0.172 & 0.003 \\
\hline GPS4 & Graft Pist. Tree 4 & 217 & 5 & 155.76 & 13.59 & 0.008 & 0.001 & 0.004 & 0.001 & 0.108 & 0.002 \\
\hline GPF4 & Graft Pist. Tree 4 & 24 & 1 & 7.42 & 0.99 & $<0.001$ & 0 & $<0.001$ & 0 & 0.007 & 0.001 \\
\hline NPL1 & Natural Pist. Tree 1 & 23 & 1 & 11.16 & 1.26 & $<0.001$ & 0 & $<0.002$ & 0 & 0.016 & 0.001 \\
\hline NPS1 & Natural Pist. Tree 1 & 78 & 4 & 145.35 & 11.51 & 0.008 & 0.001 & $<0.003$ & 0 & 0.111 & 0.003 \\
\hline NPF1 & Natural Pist. Tree 1 & 8 & 0 & 3.65 & 0.41 & 0 & 0 & $<0.001$ & 0 & 0.005 & 0 \\
\hline NPL2 & Natural Pist. Tree 2 & 139 & 3 & 78.02 & 6.95 & 0.009 & 0.001 & 0.005 & 0.001 & 0.132 & 0.003 \\
\hline NPS2 & Natural Pist. Tree 2 & 77 & 2 & 185.64 & 16.2 & 0.008 & 0.001 & 0.007 & 0.001 & 0.105 & 0.002 \\
\hline NPF2 & Natural Pist. Tree 2 & 36 & 1 & 21.1 & 2.01 & $<0.001$ & 0 & $<0.002$ & 0 & 0.022 & 0.001 \\
\hline NPL3 & Natural Pist. Tree 3 & 127 & 3 & 131.55 & 11.47 & 0.008 & 0.001 & 0.005 & 0.001 & 0.106 & 0.002 \\
\hline NPS3 & Natural Pist. Tree 3 & 82 & 4 & 182.02 & 14.38 & 0.007 & 0.001 & 0.005 & 0.001 & 0.119 & 0.003 \\
\hline NPF3 & Natural Pist. Tree 3 & 29 & 1 & 14.04 & 1.41 & $<0.002$ & 0 & $<0.002$ & 0 & 0.022 & 0.002 \\
\hline POL1 & Pomegranate Tree 1 & 96 & 3 & 180.96 & 15.78 & 0.006 & 0.001 & 0.004 & 0.001 & 0.078 & 0.002 \\
\hline
\end{tabular}


Table A.1, Part 6. Concentrations of Elements in Botanical and Soil Samples (ppm)

\begin{tabular}{|c|c|c|c|c|c|c|c|c|c|c|c|}
\hline Sample Code & Crop/Fruit & Sodium & $\mathbf{\pm} \mathbf{1} \boldsymbol{\sigma}$ & Strontium & $\mathbf{\pm 1 \sigma}$ & Tantalum & $\mathbf{\pm 1 \sigma}$ & Terbium & $\mathbf{\pm 1 \sigma}$ & Thorium & $\mathbf{\pm 1 \boldsymbol { \sigma }}$ \\
\hline POS1 & Pomegranate Tree 1 & 132 & 3 & 130.19 & 11.34 & 0.004 & 0 & 0.002 & 0.001 & 0.044 & 0.001 \\
\hline POF1 & Pomegranate Tree 1 & 39 & 2 & 19.47 & 1.84 & $<0.002$ & 0 & $<0.002$ & 0 & $<0.005$ & 0 \\
\hline POL4 & Pomegranate Tree 4 & 74 & 2 & 161.42 & 14.13 & 0.004 & 0.001 & 0.005 & 0.001 & 0.059 & 0.002 \\
\hline POS4 & Pomegranate Tree 4 & 121 & 3 & 153.09 & 13.35 & $<0.001$ & 0 & $<0.002$ & 0 & 0.035 & 0.002 \\
\hline POF4 & Pomegranate Tree 4 & 106 & 5 & 12.07 & 1.32 & $<0.002$ & 0 & $<0.002$ & 0 & $<0.005$ & 0 \\
\hline POL5 & Pomegranate Tree 5 & 67 & 2 & 139.39 & 12.17 & 0.005 & 0.001 & $<0.002$ & 0 & 0.06 & 0.002 \\
\hline POS5 & Pomegranate Tree 5 & 109 & 2 & 129.1 & 11.27 & $<0.001$ & 0 & $<0.002$ & 0 & 0.023 & 0.001 \\
\hline POF5 & Pomegranate Tree 5 & 77 & 2 & 16.54 & 1.72 & $<0.001$ & 0 & $<0.002$ & 0 & $<0.004$ & 0 \\
\hline NYE & County Soil 1 & 19603 & 395 & 509.45 & 56.63 & 1.299 & 0.058 & 0.714 & 0.057 & 17.002 & 0.176 \\
\hline NYE & County Soil 2 & 20500 & 413 & 476.53 & 54.69 & 1.254 & 0.056 & 0.843 & 0.07 & 15.912 & 0.168 \\
\hline NYE & County Soil 3 & 18916 & 383 & 431.72 & 52.19 & 1.233 & 0.057 & 0.737 & 0.063 & 15.935 & 0.168 \\
\hline Soil XRF & & 20000 & & 413 & & & & & & 19 & \\
\hline
\end{tabular}

2) Sodium measured in ashed samples 
Table A.1, Part 7. Concentrations of Elements in Botanical and Soil Samples (ppm)

\begin{tabular}{|c|c|c|c|c|c|c|c|c|c|}
\hline Sample Code & Crop/Fruit & Titanium & $\pm 1 \sigma$ & Uranium $^{(a)}$ & $\pm 1 \sigma$ & Uranium $^{(\mathbf{b})}$ & $\pm 1 \sigma$ & Vanadium & $\pm 1 \sigma$ \\
\hline AF1 & Alfalfa & $<33$ & 17 & $<0.029$ & 0.001 & $<0.029$ & 0.001 & $<0.45$ & 0.1 \\
\hline AF2 & Alfalfa & 0 & 0 & $<0.027$ & 0.001 & $<0.027$ & 0.001 & $<0.44$ & 0.14 \\
\hline AF3 & Alfalfa & 0 & 0 & $<0.025$ & 0.001 & $<0.024$ & 0.001 & $<0.46$ & 0.15 \\
\hline AF4 & Alfalfa & 0 & 0 & $<0.029$ & 0.001 & $<0.029$ & 0.001 & $<0.44$ & 0.14 \\
\hline AF5 & Alfalfa & 0 & 0 & $<0.027$ & 0.001 & $<0.027$ & 0.001 & $<0.49$ & 0.16 \\
\hline ALL1 & Almond Tree 1 & 11 & 9 & $<0.021$ & 0.001 & $<0.021$ & 0.001 & 0.31 & 0.12 \\
\hline ALS1 & Almond Tree 1 & $<15$ & 8 & $<0.013$ & 0 & $<0.013$ & 0 & $<0.14$ & 0.03 \\
\hline ALF1 & Almond Tree 1 & 7 & 6 & $<0.018$ & 0.001 & $<0.017$ & 0 & 0.21 & 0.07 \\
\hline ALL2 & Almond Tree 2 & 0 & 0 & 0.057 & 0.011 & 0.045 & 0.01 & $<0.31$ & 0.1 \\
\hline ALS2 & Almond Tree 2 & 0 & 0 & $<0.007$ & 0 & $<0.007$ & 0 & $<0.08$ & 0.02 \\
\hline ALF2 & Almond Tree 2 & 0 & 0 & 0.03 & 0.006 & $<0.016$ & 0 & 0.34 & 0.11 \\
\hline ALF4 & Almond Tree 4 & 0 & 0 & $<0.018$ & 0.001 & 0.028 & 0.007 & 0.23 & 0.08 \\
\hline ALF5 & Almond Tree 5 & 0 & 0 & $<0.014$ & 0 & $<0.014$ & 0 & $<0.12$ & 0.03 \\
\hline ALF6 & Almond Tree 6 & 0 & 0 & $<0.015$ & 0 & $<0.014$ & 0 & $<0.11$ & 0.03 \\
\hline APL1 & Apple Tree 1 & 0 & 0 & 0.035 & 0.006 & 0.034 & 0.005 & 0.48 & 0.15 \\
\hline APS1 & Apple Tree 1 & 0 & 0 & $<0.012$ & 0 & $<0.012$ & 0 & $<0.10$ & 0.03 \\
\hline APF1 & Apple Tree 1 & 0 & 0 & $<0.011$ & 0 & $<0.010$ & 0 & $<0.05$ & 0.01 \\
\hline APL2 & Apple Tree 2 & 0 & 0 & 0.06 & 0.01 & 0.039 & 0.008 & 0.58 & 0.18 \\
\hline APS2 & Apple Tree 2 & 0 & 0 & $<0.009$ & 0 & $<0.009$ & 0 & $<0.10$ & 0.03 \\
\hline APF2 & Apple Tree 2 & 0 & 0 & $<0.010$ & 0 & $<0.009$ & 0 & $<0.06$ & 0.02 \\
\hline ARS4 & Apricot Tree 4 & 0 & 0 & $<0.012$ & 0 & $<0.011$ & 0 & $<0.09$ & 0.02 \\
\hline ARF4 & Apricot Tree 4 & 0 & 0 & 0.053 & 0.008 & 0.047 & 0.007 & 0.24 & 0.08 \\
\hline ARL5 & Apricot Tree 5 & 0 & 0 & $<0.014$ & 0 & $<0.013$ & 0 & $<0.10$ & 0.03 \\
\hline ARS5 & Apricot Tree 5 & 0 & 0 & $<0.024$ & 0.001 & 0.037 & 0.006 & 0.45 & 0.15 \\
\hline ARF5 & Apricot Composite & 0 & 0 & $<0.017$ & 0.001 & $<0.016$ & 0 & $<0.08$ & 0.02 \\
\hline CRL1 & Carob Tree 1 & 0 & 0 & $<0.022$ & 0.001 & $<0.021$ & 0.001 & $<0.20$ & 0.05 \\
\hline CRS1 & Carob Tree 1 & 0 & 0 & $<0.011$ & 0 & $<0.011$ & 0 & $<0.11$ & 0.03 \\
\hline CRF1a & Carob Tree 1 & 0 & 0 & $<0.016$ & 0.001 & $<0.015$ & 0 & $<0.14$ & 0.04 \\
\hline CRF1b & Carob Tree 1 & 0 & 0 & $<0.016$ & 0.001 & $<0.015$ & 0 & $<0.12$ & 0.03 \\
\hline CRL2 & Carob Tree 2 & 0 & 0 & $<0.018$ & 0.001 & 0.014 & 0.006 & $<0.21$ & 0.04 \\
\hline CRS2 & Carob Tree 2 & 0 & 0 & $<0.009$ & 0 & $<0.009$ & 0 & $<0.11$ & 0.02 \\
\hline CRF2a & Carob Tree 2 & 0 & 0 & $<0.017$ & 0.001 & $<0.016$ & 0.001 & $<0.14$ & 0.03 \\
\hline CRF2b & Carob Tree 2 & 0 & 0 & $<0.010$ & 0 & $<0.009$ & 0 & $<0.14$ & 0.03 \\
\hline FIL & Fig Tree 1 & 0 & 0 & 0.09 & 0.014 & 0.076 & 0.012 & 0.75 & 0.19 \\
\hline FIS & Fig Tree 1 & 0 & 0 & $<0.014$ & 0 & $<0.014$ & 0 & $<0.24$ & 0.05 \\
\hline FIF & Fig Tree 1 & 0 & 0 & $<0.017$ & 0 & $<0.016$ & 0 & $<0.22$ & 0.05 \\
\hline FIL & Fig Tree 3 & 0 & 0 & 0.125 & 0.015 & 0.137 & 0.015 & 0.67 & 0.19 \\
\hline FIS & Fig Tree 3 & 0 & 0 & $<0.010$ & 0 & 0.007 & 0.003 & $<0.18$ & 0.04 \\
\hline FIF & Fig Tree 3 & 0 & 0 & $<0.012$ & 0 & $<0.012$ & 0 & $<0.18$ & 0.04 \\
\hline FIF & Fig Tree 2 & 0 & 0 & $<0.015$ & 0 & $<0.014$ & 0 & $<0.23$ & 0.05 \\
\hline FIF & Fig Tree 4 & 0 & 0 & $<0.022$ & 0.001 & $<0.022$ & 0.001 & $<0.19$ & 0.04 \\
\hline FIF & Fig Tree 5 & 0 & 0 & $<0.018$ & 0.001 & $<0.018$ & 0.001 & $<0.20$ & 0.04 \\
\hline
\end{tabular}


Table A.1, Part 7. Concentrations of Elements in Botanical and Soil Samples (ppm)

\begin{tabular}{|c|c|c|c|c|c|c|c|c|c|}
\hline Sample Code & Crop/Fruit & Titanium & $\pm 1 \sigma$ & Uranium $^{(a)}$ & $\pm 1 \sigma$ & Uranium $^{(\mathbf{b})}$ & $\pm 1 \sigma$ & Vanadium & $\pm 1 \sigma$ \\
\hline GRL1 & Grape Vine 1 & 0 & 0 & $<0.027$ & 0.001 & $<0.026$ & 0.001 & $<0.27$ & 0.06 \\
\hline GRS1 & Grape Vine 1 & 0 & 0 & $<0.018$ & 0 & $<0.018$ & 0 & $<0.26$ & 0.06 \\
\hline GRF1 & Grape Vine 1 & 0 & 0 & $<0.038$ & 0.001 & $<0.038$ & 0.001 & $<0.41$ & 0.09 \\
\hline GRL2 & Grape Vine 2 & 0 & 0 & $<0.023$ & 0.001 & $<0.022$ & 0.001 & $<0.32$ & 0.07 \\
\hline GRS2.3 & Grape Vine 2 & 0 & 0 & $<0.034$ & 0.001 & $<0.033$ & 0.001 & $<0.45$ & 0.09 \\
\hline GRS2.4 & Grape Vine 2 & 0 & 0 & $<0.053$ & 0.001 & $<0.053$ & 0.001 & $<0.42$ & 0.09 \\
\hline GRF2.2 & Grape Vine 2 & 0 & 0 & $<0.015$ & 0 & $<0.014$ & 0 & $<0.14$ & 0.03 \\
\hline GRF2.3 & Grape Vine 2 & 0 & 0 & $<0.018$ & 0 & $<0.017$ & 0 & $<0.14$ & 0.03 \\
\hline NCL1 & Nectarine Tree 1 & 0 & 0 & 0.043 & 0.007 & 0.048 & 0.008 & $<0.24$ & 0.05 \\
\hline NCS1 & Nectarine Tree 1 & 0 & 0 & $<0.009$ & 0 & $<0.009$ & 0 & $<0.15$ & 0.03 \\
\hline NCF1 & Nectarine Tree 1 & 0 & 0 & $<0.012$ & 0 & $<0.011$ & 0 & $<0.09$ & 0.02 \\
\hline NCL3 & Nectarine Tree 3 & 0 & 0 & 0.032 & 0.006 & 0.029 & 0.006 & $<0.25$ & 0.05 \\
\hline NCS3 & Nectarine Tree 3 & 0 & 0 & $<0.007$ & 0 & $<0.006$ & 0 & $<0.08$ & 0.01 \\
\hline FO1 & Feed Oats & 0 & 0 & $<0.032$ & 0.001 & $<0.033$ & 0.001 & $<0.22$ & 0.04 \\
\hline FO4 & Feed Oats & 0 & 0 & $<0.035$ & 0.001 & $<0.036$ & 0.001 & $<0.23$ & 0.04 \\
\hline FO6 & Feed Oats & 0 & 0 & $<0.037$ & 0.001 & $<0.038$ & 0.001 & $<0.22$ & 0.03 \\
\hline FO8 & Feed Oats & 0 & 0 & $<0.035$ & 0.001 & $<0.035$ & 0.001 & $<0.24$ & 0.04 \\
\hline $\mathrm{PCL}$ & Pecan & 0 & 0 & $<0.020$ & 0 & $<0.020$ & 0.001 & $<0.27$ & 0.04 \\
\hline PCS & Pecan & 0 & 0 & $<0.009$ & 0 & $<0.009$ & 0 & $<0.11$ & 0.02 \\
\hline PCF & Pecan & 0 & 0 & $<0.010$ & 0 & $<0.010$ & 0 & $<0.09$ & 0.01 \\
\hline GPL1 & Graft Pist. Tree 1 & 0 & 0 & $<0.025$ & 0.001 & $<0.026$ & 0.001 & $<0.24$ & 0.04 \\
\hline GPS1 & Graft Pist. Tree 1 & 0 & 0 & $<0.007$ & 0 & $<0.007$ & 0 & $<0.09$ & 0.01 \\
\hline GPF1 & Graft Pist. Tree 1 & 0 & 0 & $<0.012$ & 0 & $<0.011$ & 0 & $<0.07$ & 0.01 \\
\hline GPL2 & Graft Pist. Tree 2 & 0 & 0 & $<0.022$ & 0.001 & $<0.023$ & 0.001 & $<0.25$ & 0.04 \\
\hline GPS2 & Graft Pist. Tree 2 & 0 & 0 & 0.041 & 0.007 & 0.047 & 0.007 & 0.35 & 0.08 \\
\hline GPF2 & Graft Pist. Tree 2 & 0 & 0 & $<0.010$ & 0 & $<0.010$ & 0 & $<0.07$ & 0.01 \\
\hline GPL3 & Graft Pist. Tree 3 & 0 & 0 & $<0.024$ & 0.001 & $<0.026$ & 0.001 & $<0.25$ & 0.04 \\
\hline GPS3 & Graft Pist. Tree 3 & 0 & 0 & 0.008 & 0.003 & $<0.008$ & 0 & 0.14 & 0.06 \\
\hline GPF3 & Graft Pist. Tree 3 & 0 & 0 & $<0.011$ & 0 & $<0.011$ & 0 & $<0.08$ & 0.01 \\
\hline GPL4 & Graft Pist. Tree 4 & 0 & 0 & 0.028 & 0.007 & 0.039 & 0.007 & $<0.21$ & 0.03 \\
\hline GPS4 & Graft Pist. Tree 4 & 0 & 0 & 0.027 & 0.005 & 0.025 & 0.004 & 0.44 & 0.09 \\
\hline GPF4 & Graft Pist. Tree 4 & 0 & 0 & $<0.011$ & 0 & $<0.010$ & 0 & $<0.07$ & 0.01 \\
\hline NPL1 & Natural Pist. Tree 1 & 0 & 0 & $<0.011$ & 0 & $<0.011$ & 0 & $<0.18$ & 0.03 \\
\hline NPS1 & Natural Pist. Tree 1 & 0 & 0 & 0.02 & 0.006 & 0.02 & 0.005 & 0.41 & 0.09 \\
\hline NPF1 & Natural Pist. Tree 1 & 0 & 0 & $<0.004$ & 0 & $<0.004$ & 0 & $<0.10$ & 0.02 \\
\hline NPL2 & Natural Pist. Tree 2 & 0 & 0 & 0.023 & 0.006 & 0.018 & 0.006 & 0.33 & 0.09 \\
\hline NPS2 & Natural Pist. Tree 2 & 0 & 0 & 0.02 & 0.003 & 0.018 & 0.003 & 0.33 & 0.07 \\
\hline NPF2 & Natural Pist. Tree 2 & 0 & 0 & $<0.013$ & 0 & $<0.013$ & 0 & $<0.23$ & 0.04 \\
\hline NPL3 & Natural Pist. Tree 3 & 0 & 0 & 0.018 & 0.004 & 0.024 & 0.005 & $<0.33$ & 0.06 \\
\hline NPS3 & Natural Pist. Tree 3 & 0 & 0 & 0.028 & 0.005 & 0.026 & 0.006 & $<0.24$ & 0.04 \\
\hline NPF3 & Natural Pist. Tree 3 & 0 & 0 & $<0.017$ & 0.001 & $<0.016$ & 0.001 & $<0.16$ & 0.03 \\
\hline POL1 & Pomegranate Tree 1 & 0 & 0 & $<0.024$ & 0.001 & $<0.026$ & 0.001 & $<0.46$ & 0.09 \\
\hline
\end{tabular}


Table A.1, Part 7. Concentrations of Elements in Botanical and Soil Samples (ppm)

\begin{tabular}{|c|c|c|c|c|c|c|c|c|c|}
\hline Sample Code & Crop/Fruit & Titanium & $\mathbf{\pm 1 \sigma}$ & Uranium $^{(\mathbf{a})}$ & $\mathbf{\pm 1} \boldsymbol{\sigma}$ & Uranium $^{(\mathbf{b})}$ & $\mathbf{\pm 1 \sigma}$ & Vanadium & $\mathbf{\pm 1 \boldsymbol { \sigma }}$ \\
\hline POS1 & Pomegranate Tree 1 & 0 & 0 & $<0.010$ & 0 & 0.007 & 0.004 & $<0.27$ & 0.05 \\
\hline POF1 & Pomegranate Tree 1 & 0 & 0 & $<0.029$ & 0.001 & $<0.029$ & 0.001 & $<0.33$ & 0.06 \\
\hline POL4 & Pomegranate Tree 4 & 0 & 0 & $<0.021$ & 0.001 & $<0.022$ & 0.001 & $<0.56$ & 0.1 \\
\hline POS4 & Pomegranate Tree 4 & 0 & 0 & $<0.011$ & 0 & $<0.011$ & 0 & $<0.32$ & 0.06 \\
\hline POF4 & Pomegranate Tree 4 & 0 & 0 & $<0.023$ & 0.001 & $<0.023$ & 0.001 & $<0.37$ & 0.07 \\
\hline POL5 & Pomegranate Tree 5 & 0 & 0 & $<0.018$ & 0 & $<0.019$ & 0 & $<0.52$ & 0.09 \\
\hline POS5 & Pomegranate Tree 5 & 0 & 0 & $<0.011$ & 0 & $<0.011$ & 0 & $<0.32$ & 0.06 \\
\hline POF5 & Pomegranate Tree 5 & 0 & 0 & $<0.016$ & 0 & $<0.016$ & 0 & $<0.37$ & 0.07 \\
\hline NYE & County Soil 1 & 1995.7 & 284.5 & 3.732 & 0.334 & 3.131 & 0.257 & 24.4 & 2.9 \\
\hline NYE & County Soil 2 & 2423.2 & 364 & 3.799 & 0.354 & 3.025 & 0.276 & 23.5 & 2.7 \\
\hline NYE & County Soil 3 & 1834.2 & 314.5 & 3.658 & 0.329 & 3.204 & 0.297 & 22.9 & 3.1 \\
\hline Soil XRF & & & & & & & & 24 & \\
\hline
\end{tabular}

Uranium concentrations estimated on the basis of 2 decay energy peaks: a) 228 and b) $277 \mathrm{keV}$. 
Table A.1, Part 8. Concentrations of Elements in Botanical and Soil Samples (ppm)

\begin{tabular}{|c|c|c|c|c|c|c|c|}
\hline Sample Code & Crop/Fruit & Ytterbium & $\pm 1 \sigma$ & Zinc & $\pm 1 \sigma$ & Zirconium & $\pm 1 \sigma$ \\
\hline AF1 & Alfalfa & $<0.007$ & 0 & 9.08 & 0.28 & $<0.81$ & \\
\hline AF2 & Alfalfa & $<0.007$ & 0 & 8.56 & 0.26 & $<0.92$ & \\
\hline AF3 & Alfalfa & $<0.006$ & 0 & 9.63 & 0.3 & $<0.78$ & \\
\hline AF4 & Alfalfa & $<0.007$ & 0 & 7.95 & 0.25 & $<0.89$ & \\
\hline AF5 & Alfalfa & $<0.007$ & 0 & 8.92 & 0.27 & $<0.78$ & \\
\hline ALL1 & Almond Tree 1 & 0.007 & 0.002 & 4.94 & 0.16 & $<0.99$ & \\
\hline ALS1 & Almond Tree 1 & 0.006 & 0.001 & 2.56 & 0.09 & $<0.58$ & \\
\hline ALF1 & Almond Tree 1 & 0.007 & 0.002 & 5.62 & 0.18 & $<0.98$ & \\
\hline ALL2 & Almond Tree 2 & 0.032 & 0.004 & 6.1 & 0.2 & 2.35 & 0.66 \\
\hline ALS2 & Almond Tree 2 & 0.003 & 0.001 & 3.11 & 0.1 & $<0.40$ & \\
\hline ALF2 & Almond Tree 2 & 0.014 & 0.002 & 8.63 & 0.26 & 1.55 & 0.42 \\
\hline ALF4 & Almond Tree 4 & 0.009 & 0.002 & 8.1 & 0.25 & 1.3 & 0.43 \\
\hline ALF5 & Almond Tree 5 & 0.011 & 0.002 & 5.08 & 0.16 & $<0.85$ & \\
\hline ALF6 & Almond Tree 6 & 0.006 & 0.001 & 5.29 & 0.17 & $<0.85$ & \\
\hline APL1 & Apple Tree 1 & 0.013 & 0.002 & 9.62 & 0.3 & $<1.08$ & \\
\hline APS1 & Apple Tree 1 & $<0.003$ & 0 & 19.54 & 0.59 & $<0.66$ & \\
\hline APF1 & Apple Tree 1 & $<0.003$ & 0 & 1.23 & 0.05 & $<0.70$ & \\
\hline APL2 & Apple Tree 2 & 0.024 & 0.003 & 9.38 & 0.32 & 1.94 & 1.04 \\
\hline APS2 & Apple Tree 2 & 0.002 & 0.001 & 5.53 & 0.18 & $<0.66$ & \\
\hline APF2 & Apple Tree 2 & $<0.002$ & 0 & 1.17 & 0.05 & $<0.81$ & \\
\hline ARS4 & Apricot Tree 4 & $<0.003$ & 0 & 6.61 & 0.22 & $<0.68$ & \\
\hline ARF4 & Apricot Tree 4 & 0.01 & 0.002 & 8.24 & 0.28 & $<1.90$ & \\
\hline ARL5 & Apricot Tree 5 & 0.002 & 0.001 & 10.5 & 0.34 & $<0.88$ & \\
\hline ARS5 & Apricot Tree 5 & 0.009 & 0.002 & 7.63 & 0.26 & $<1.66$ & \\
\hline ARF5 & Apricot Composite & $<0.004$ & 0 & 4.26 & 0.14 & $<1.19$ & \\
\hline CRL1 & Carob Tree 1 & 0.009 & 0.002 & 10.99 & 0.36 & $<1.10$ & \\
\hline CRS1 & Carob Tree 1 & 0.009 & 0.001 & 7.14 & 0.24 & $<0.97$ & \\
\hline CRF1a & Carob Tree 1 & 0.006 & 0.001 & 16.94 & 0.55 & $<1.01$ & \\
\hline CRF1b & Carob Tree 1 & $<0.004$ & 0 & 11.97 & 0.39 & $<1.11$ & \\
\hline CRL2 & Carob Tree 2 & 0.009 & 0.002 & 7.71 & 0.25 & $<0.97$ & \\
\hline CRS2 & Carob Tree 2 & 0.003 & 0.001 & 4.42 & 0.15 & $<0.84$ & \\
\hline CRF2a & Carob Tree 2 & $<0.004$ & 0 & 10.98 & 0.36 & $<1.24$ & \\
\hline CRF2b & Carob Tree 2 & $<0.003$ & 0 & 9.52 & 0.29 & $<0.51$ & \\
\hline FIL & Fig Tree 1 & 0.055 & 0.004 & 11.63 & 0.39 & 4.14 & 1.84 \\
\hline FIS & Fig Tree 1 & $<0.004$ & 0 & 5.79 & 0.18 & $<0.40$ & \\
\hline FIF & Fig Tree 1 & $<0.005$ & 0 & 7.25 & 0.22 & $<0.52$ & \\
\hline FIL & Fig Tree 3 & 0.059 & 0.006 & 10.65 & 0.33 & 5.26 & 1.03 \\
\hline FIS & Fig Tree 3 & 0.004 & 0.001 & 5.47 & 0.17 & $<0.37$ & \\
\hline FIF & Fig Tree 3 & $<0.004$ & 0 & 6.3 & 0.19 & $<0.44$ & \\
\hline FIF & Fig Tree 2 & $<0.004$ & 0 & 9.17 & 0.28 & $<0.48$ & \\
\hline FIF & Fig Tree 4 & $<0.008$ & 0 & 11.3 & 0.35 & $<0.89$ & \\
\hline FIF & Fig Tree 5 & $<0.005$ & 0 & 11.86 & 0.37 & $<0.92$ & \\
\hline
\end{tabular}


Table A.1, Part 8. Concentrations of Elements in Botanical and Soil Samples (ppm)

\begin{tabular}{|c|c|c|c|c|c|c|c|}
\hline Sample Code & Crop/Fruit & Ytterbium & $\pm 1 \sigma$ & Zinc & $\pm 1 \sigma$ & Zirconium & $\pm 1 \sigma$ \\
\hline GRL1 & Grape Vine 1 & 0.018 & 0.003 & 11.81 & 0.36 & $<1.02$ & \\
\hline GRS1 & Grape Vine 1 & $<0.005$ & 0 & 21.79 & 0.65 & $<0.59$ & \\
\hline GRF1 & Grape Vine 1 & $<0.010$ & 0 & 14.6 & 0.44 & $<0.81$ & \\
\hline GRL2 & Grape Vine 2 & 0.013 & 0.003 & 10.22 & 0.31 & $<0.95$ & \\
\hline GRS2.3 & Grape Vine 2 & $<0.008$ & 0 & 13.47 & 0.4 & $<0.70$ & \\
\hline GRS2.4 & Grape Vine 2 & $<0.015$ & 0 & 17.18 & 0.53 & $<1.18$ & \\
\hline GRF2.2 & Grape Vine 2 & $<0.004$ & 0 & 5 & 0.15 & $<0.59$ & \\
\hline GRF2.3 & Grape Vine 2 & $<0.005$ & 0 & 4.45 & 0.14 & $<0.76$ & \\
\hline NCL1 & Nectarine Tree 1 & 0.016 & 0.002 & 6.18 & 0.19 & $<1.06$ & \\
\hline NCS1 & Nectarine Tree 1 & 0.004 & 0.001 & 13.57 & 0.41 & $<0.56$ & \\
\hline NCF1 & Nectarine Tree 1 & $<0.003$ & 0 & 6.84 & 0.21 & $<0.80$ & \\
\hline NCL3 & Nectarine Tree 3 & 0.015 & 0.002 & 8.75 & 0.26 & $<0.88$ & \\
\hline NCS3 & Nectarine Tree 3 & $<0.002$ & 0 & 3.62 & 0.11 & $<0.37$ & \\
\hline FO1 & Feed Oats & $<0.009$ & 0 & 13.56 & 0.42 & $<1.01$ & \\
\hline FO4 & Feed Oats & $<0.010$ & 0 & 10.77 & 0.33 & $<1.06$ & \\
\hline FO6 & Feed Oats & $<0.011$ & 0 & 13.15 & 0.41 & $<1.14$ & \\
\hline FO8 & Feed Oats & $<0.010$ & 0 & 9.43 & 0.32 & $<1.26$ & \\
\hline PCL & Pecan & 0.009 & 0.002 & 10.75 & 0.32 & $<0.67$ & \\
\hline PCS & Pecan & $<0.003$ & 0 & 6.72 & 0.2 & $<0.44$ & \\
\hline PCF & Pecan & $<0.003$ & 0 & 11.74 & 0.35 & $<0.54$ & \\
\hline GPL1 & Graft Pist. Tree 1 & 0.012 & 0.003 & 8.41 & 0.28 & $<1.21$ & \\
\hline GPS1 & Graft Pist. Tree 1 & 0.003 & 0.001 & 7.5 & 0.25 & $<0.67$ & \\
\hline GPF1 & Graft Pist. Tree 1 & $<0.003$ & 0 & 10.67 & 0.35 & $<0.76$ & \\
\hline GPL2 & Graft Pist. Tree 2 & 0.009 & 0.003 & 7.99 & 0.26 & $<1.06$ & \\
\hline GPS2 & Graft Pist. Tree 2 & 0.032 & 0.003 & 4.58 & 0.19 & 4.56 & 1.92 \\
\hline GPF2 & Graft Pist. Tree 2 & $<0.004$ & 0 & 4.78 & 0.16 & $<0.81$ & \\
\hline GPL3 & Graft Pist. Tree 3 & 0.016 & 0.003 & 5.94 & 0.21 & $<1.37$ & \\
\hline GPS3 & Graft Pist. Tree 3 & 0.008 & 0.001 & 4.73 & 0.16 & $<0.85$ & \\
\hline GPF3 & Graft Pist. Tree 3 & $<0.004$ & 0 & 6.04 & 0.2 & $<0.84$ & \\
\hline GPL4 & Graft Pist. Tree 4 & 0.021 & 0.003 & 10.68 & 0.36 & $<1.68$ & \\
\hline GPS4 & Graft Pist. Tree 4 & 0.018 & 0.002 & 8.72 & 0.29 & $<1.23$ & \\
\hline GPF4 & Graft Pist. Tree 4 & $<0.003$ & 0 & 9.56 & 0.31 & $<0.72$ & \\
\hline NPL1 & Natural Pist. Tree 1 & $<0.004$ & 0 & 5.44 & 0.18 & $<0.95$ & \\
\hline NPS1 & Natural Pist. Tree 1 & 0.018 & 0.002 & 1.66 & 0.1 & $<1.87$ & \\
\hline NPF1 & Natural Pist. Tree 1 & $<0.001$ & 0 & 1.65 & 0.06 & $<0.30$ & \\
\hline NPL2 & Natural Pist. Tree 2 & 0.016 & 0.003 & 5.96 & 0.21 & $<1.47$ & \\
\hline NPS2 & Natural Pist. Tree 2 & 0.018 & 0.001 & 2.13 & 0.09 & $<1.10$ & \\
\hline NPF2 & Natural Pist. Tree 2 & $<0.004$ & 0 & 5.45 & 0.18 & $<0.85$ & \\
\hline NPL3 & Natural Pist. Tree 3 & 0.014 & 0.002 & 7.58 & 0.25 & 0.98 & 0.41 \\
\hline NPS3 & Natural Pist. Tree 3 & 0.019 & 0.002 & 4.41 & 0.18 & $<1.78$ & \\
\hline NPF3 & Natural Pist. Tree 3 & $<0.004$ & 0 & 7.78 & 0.26 & $<1.20$ & \\
\hline POL1 & Pomegranate Tree 1 & 0.015 & 0.003 & 7.6 & 0.25 & $<1.03$ & \\
\hline
\end{tabular}


Table A.1, Part 8. Concentrations of Elements in Botanical and Soil Samples (ppm)

\begin{tabular}{|c|c|c|c|c|c|c|c|}
\hline Sample Code & Crop/Fruit & Ytterbium & $\mathbf{\pm 1 \sigma}$ & Zinc & $\mathbf{\pm 1 \boldsymbol { \sigma }}$ & Zirconium & $\mathbf{\pm 1 \boldsymbol { \sigma }}$ \\
\hline POS1 & Pomegranate Tree 1 & 0.007 & 0.001 & 6.8 & 0.22 & $<0.69$ & \\
\hline POF1 & Pomegranate Tree 1 & $<0.009$ & 0 & 8.5 & 0.29 & $<1.27$ & \\
\hline POL4 & Pomegranate Tree 4 & 0.007 & 0.002 & 7.55 & 0.25 & $<1.01$ & \\
\hline POS4 & Pomegranate Tree 4 & $<0.004$ & 0 & 8.15 & 0.27 & $<0.87$ & \\
\hline POF4 & Pomegranate Tree 4 & $<0.006$ & 0 & 8.24 & 0.29 & $<1.30$ & \\
\hline POL5 & Pomegranate Tree 5 & 0.007 & 0.002 & 5.43 & 0.18 & $<0.89$ & \\
\hline POS5 & Pomegranate Tree 5 & $<0.004$ & 0 & 8.72 & 0.29 & $<0.79$ & \\
\hline POF5 & Pomegranate Tree 5 & $<0.006$ & 0 & 8.49 & 0.28 & $<0.92$ & \\
\hline NYE & County Soil 1 & 2.493 & 0.087 & 53.15 & 2.76 & 296.28 & 62.2 \\
\hline NYE & County Soil 2 & 2.256 & 0.085 & 56.12 & 2.67 & 215.76 & 47.7 \\
\hline NYE & County Soil 3 & 2.167 & 0.079 & 57.68 & 2.74 & 206.34 & 46.4 \\
\hline Soil XRF & & & & 53 & & 256 & \\
\hline
\end{tabular}





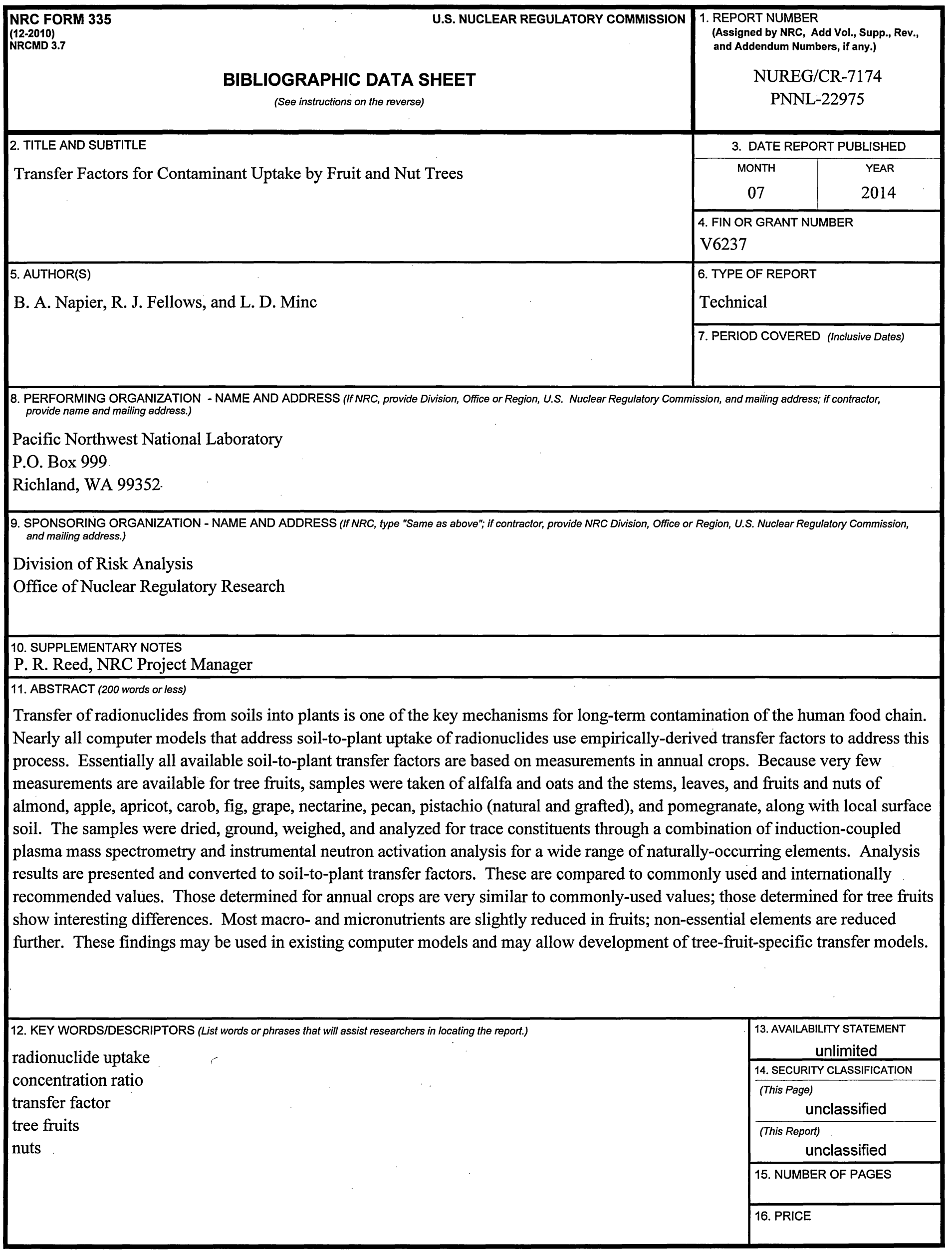




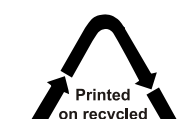

Printed
on recycled
paper

paper

Federal Recycling Program 



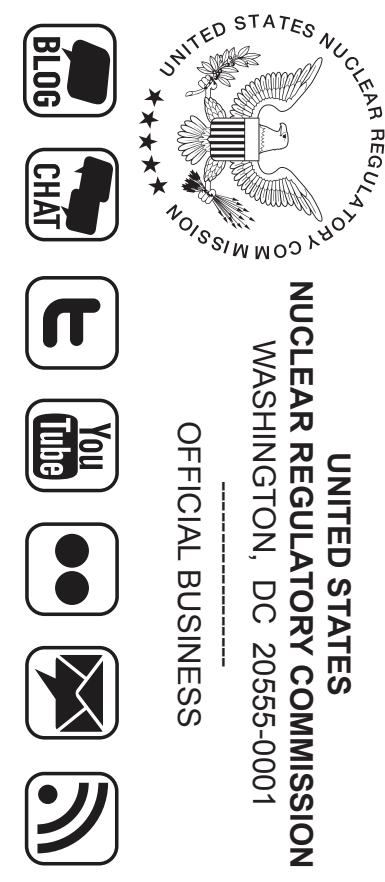




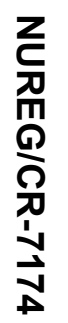

궁

$\frac{c}{2}$
$\frac{1}{0}$
$\frac{1}{1}$ 